DR.1')3

Coo-4635-1

$(\theta)$

THE GEOTHERMAL LOAN GUARANTY PROGRAM AND ITS IMPACT ON GEOTHERMAL EXPLORATION AND DEVELOPMENT

By

Louise H. Nash

May 1978

Work Performed Under Contract No. ET-78-C-02-4635

MASTER

Colorado School of Mines

Golden, Colorado

U. S. DEPARTMENT OF ENERGY Geothermal Energy 


\section{DISCLAIMER}

This report was prepared as an account of work sponsored by an agency of the United States Government. Neither the United States Government nor any agency Thereof, nor any of their employees, makes any warranty, express or implied, or assumes any legal liability or responsibility for the accuracy, completeness, or usefulness of any information, apparatus, product, or process disclosed, or represents that its use would not infringe privately owned rights. Reference herein to any specific commercial product, process, or service by trade name, trademark, manufacturer, or otherwise does not necessarily constitute or imply its endorsement, recommendation, or favoring by the United States Government or any agency thereof. The views and opinions of authors expressed herein do not necessarily state or reflect those of the United States Government or any agency thereof. 


\section{DISCLAIMER}

Portions of this document may be illegible in electronic image products. Images are produced from the best available original document. 


\section{DISCLAIMER}

"This book was prepared as an account of work sponsored by an agency of the United States Government. Neither the United States Government nor any agency thereof, nor any of their employees, makes any warranty, express or implied, or assumes any legal liability or responsibility for the accuracy, completeness, or usefulness of any information; apparatus, product, or process disclosed, or represents that its use would not infringe privately owned rights. Reference herein to any specific commercial product, process, or service by trade name, trademark, manufacturer, or otherwise, does not necessarily constitute or imply its endorsement, recommendation, or favoring by the United States Government or any agency thereof. The views and opinions of authors expressed herein do not necessarily state or reflect those of the United States Government or any agency thereof."

This report has been printed directly from copy supplied by the originating organization. Although the copy supplied may not in part or whole meet the standards for acceptable reproducible copy, it has been used for reproduction to expedite distribution and availability of the information being reported.

Available from the National Technical Information Service, U. S. Department of Commerce, Springfield, Virginia 22161.

Price: Paper Copy $\$ 13.00$

Microfiche $\$ 3.50$ 


\title{
THE GEOTHERMAL LOAN GUARANTY PROGRAM AND ITS IMPACT ON GEOTHERMAL EXPLORATION \\ AND DEVELOPMENT
}

\author{
Louise H. Nasr
}

May 1978

\begin{abstract}
Colorado School of Mines Golden, Colorado 80401
\end{abstract}

\section{Prepared For}

U.S. Department of Energy

Under Contract No. ET-78-C-O2-4635 
19.

- 


\section{ABSTRACT}

The study provides an evaluation of the impact of the Geothermal Loan Guaranty Program on geothermal development in the United States. The report includes an assessment of the program's impact on private and public decision making for investment in geothermal resource development.

The legislative background, the current and potential applications, the operating procedures, and the review process of the Loan Guaranty Program are examined. Current problems resulting from external factors affecting the program (e.g. the ERDA-DOE transition, leasing practices, environmental regulations) are also presented.

The research methodology consisted of personal interviews with representatives of the financial community, the geothermal industry, and the utility companies. Government documents were reviewed for pertinent material. The perspective of lending institutions, private industry, and utility companies, were assessed and the conclusions were arrived at by the author as a result of an evaluation of the foregoing. 
The study showed that the Geothermal Loan Guaranty Program has had only a negligible effect on geothermal development and the response to the program was far less than expected. The streamlining of environmental regulations and leasing policies, and the granting of intangible drilling cost writeoffs and depletion allowances to operators would have had a greate? impact on geothermal energy development. The loan guaranty program did not promote the undertaking of any new projects that would not have been undertaken without it. The program only accelerated the pace for some development which might have commenced in the future.

Included in the study are recommendations for improving the operation of the program thereby increasing its attractiveness to potential applicants. 
TABLE OF CONTENTS

$\underline{\text { Page }}$

INTRODUCTION -

Data Sources and Method of Analysis -

Study Organization - 4

STATE OF THE ART - GEOTHERMAL ENERGY OVERVIEW----- - - 7

Resource Potential-

Leasing -

Drilling Activity

Status of Geothermal Prospects - 17

Nonelectric Utilization -

Industry Structure - 25

Financial Arrangements

Government and Geothermal Development - 30

THE GEOTHERMAL LOAN GUARANTY PROGRAM (GLGP) -

Legislation and objectives - 41

Budgetary Allocation - 45

Current Status of the Geothermal Loan

Guaranty Program - 47

Application Processing 58

EXTERNALITIES EFFECTING THE GEOTHERMAL LOAN

GUARANTY PROGRAM - 70

General Overview

ERDA-DOE Transition 
Page

Leasing -

Environmental Regulations - 77

Demonstration Program

EVALUATING THE GLGP: ATTITUDES AND PERSPECTIVES - - - 83

Industry's Evaluation 84

Utility Evaluation

Lending Institutions

Author's Evaluation

Problems of the GLGP

Where Are the Applicants? - 99

CONCLUSIONS AND RECOMMENDATIONS

Conclusions

Recommendations - 108

REFERENCES -

BIBLIOGRAPHICAL INFORMATION

APPENDICES - --124 


\section{LIST OF FIGURES}

$\underline{\text { Page }}$

1. Geothermal Resources Development --- 18

2. Required Temperature of Geothermal Fluids for Various Nonelectrical

Applications - -

3. Flow Chart of Application Processing-------- 60

4. Geothermal Loan Guaranty Flow Diagram, ERDA - -

5. Geothermal Loan Guaranty Flow Diagram, ERDA - - - - - - -

6. Flow Chart of Critical Path in Geothermal Exploration - 78

7. Lending Institutions and Their Interest in ERDA's Loan Guaranty Programs - 
$\underline{\text { Page }}$

1. Worldwide Approximate Electric and Nonelectric Use of Geothermal Energy, 1976

2. Existing and Expected Capacity at the Geysers Geothermal Power Plants --.------- 9

3. Geothermal Resources of Hydrothermal Convection Systems -

4. Geothermal Resources of Geopressured Sedimentary Environments -_-_-_-_- 12

5. Drilling Costs for Geothermal Wells -.----- 16

6. Geothermal Wells Drilled in the United States, 1975-77

7. Types of Firms and Involvement in Geothermal Development - 26

8. Capital Formation for Geothermal Projects----- 30

9. Estimated Geothermal Utilization Given Successful Federal Program Implementation, $1975-\ldots-0-1$

10. Intended Commercial Geothermal Utilization Potential Given Successful Federal Program Implementation, 1977 - 31

:11. Federal Budget for Geothermal, 1975-79-- 33

12. Geothermal Loan Guaranty Applications ---.-- 48

13. Current Status of Applications - 52

14. Time Taken for Application Review - 65

15. Federal Regulations Applicable to Geothermal Resource Development Projects --.------- 80 


\section{ACKNOWLEDGEMENTS}

The author is indebted to Dr. George V. Keller for his guidance and encouragement throughout the project. The author also wishes to acknowledge Dr. Oded Rudawsky, her Thesis Advisor, and Dr. Hunter Swanson who also served as committee members.

The author is grateful to Dr. William Copeland, Dean of the Graduate School, and Mr. Richard Harshman of the office of Research Services whose efforts made this project possible.

The author thanks the U.S. Department of Energy for financial assistance of this project and Dr. Donald Elmer of DOE for his support and assistance.

The author wishes to extend thanks to the many people in industry and government who gave their time and assistance to her. 


\section{INTRODUCTION}

Loan guaranties to stimulate investment and development for social or political benefit have been used in the United States for over 30 years with varying degrees of success. The use of this vehicle as an incentive to develop energy resources and technologies is new; and its success in achieving the objectives has not yet been determined.

The United States government has several programs directed at the development of geothermal resources ${ }^{(1)}$. The potential contribution of this resource to total energy supply has been estimated to be between 3-10 percent. Its role is especially significant in the western United States, where over 60 percent of geothermal resources are estimated to exist. The United States Geological Survey (CI 726, 1975) assessed the resource potential and estimated potential electric generating power to be $42,000 \mathrm{MW} \cdot$ cent $^{(2)}$ or $140,000 \mathrm{MW}$ for 30 years. Three types of geothermal resources were

(1) Geothermal resources are defined as the stored heat, both identified and undiscovered, that is recoverable using current or near current technology|regardless of cost (USGS CI 726).

(2) A megawatt century of electricity is a unit of energy equivalent to $1 \mathrm{MW}$ of power produced for 100 years (or 3.33 MW for 30 years). 
evaluated: vapor-dominated hydrothermal (3), liquid-dominated hydrothermal (4) (for temperatures of $>150^{\circ} \mathrm{C}$ and $90-150^{\circ} \mathrm{C}$ ), and geopressured fluids (5).

The Geothermal Loan Guaranty Program (GLGP) is one government support directed at developing this resource potential. Title II of the Geothermal Research, Development and Demonstration Act of 1974 (P.L. 93-410) provided the legislation for enactment of the program. The Geothermal Loan Guaranty Program was the first such program aimed at developing an energy resource and has provided a model for additional loan guaranty programs for coal, synthetic fuel, and electric and hybrid vehicles.

It is the objective of this study to evaluate the Geothermal Loan Guaranty Program, to examine its operation, and to estimate its current and potential use in developing geothermal energy.

Data Sources and Method of Analysis

Data were acquired from primary sources and personal contact with lending institutions, government, private industry, and utilities. Contacts were made on the basis of involvement

(3) Geothermal convection systems containing saturated or superheated steam.

(4) Geothermal convection systems containing hot water.

(5) Areas of abnormally high fluid pressure. 
in geothermal development and/or interest in the loan guaranty program. The San Francisco Operations office (SAN), the administrating office for the program, provided the author with a list of potential applicants as discussed in Chapter III. Government documents and internally circulated memoranda were reviewed for information and insight into the workings of the program in relation to government organization. The Department of Energy and before that, ERDA (Energy Research and Development Administration), has contracted several studies devoted to various government financial supports including loan guaranties, cost-sharing, direct grants, and tax subsidies addressing the potential for promoting development and commercialization of energy resources and technologies. Two studies by large research institutes, Harbridge House and Bradford National, deal with lending institutions' attitudes and potential activity with respect to government loan guaranties (see Bibliography).

Utilities, their involvement, obstacles, and potential for utilizing geothermal resources are well documented in two studies by Sheldon Bierman, et al: Innovation and Monopoly and Geothermal Energy and the Bulk Electric Power and Petroleum Industries (draft). Legal and tax issues are being studied extensively by Jack McNamara at the University of Southern California; two papers have been produced: 
Geothermal Energy and the Law, Vol I: The Federal Lands Management Program (draft), and Vol. II: Preliminary Analysis of the Impacts of Federal Tax Reform on Geothermal Energy Development in the United States. The U.S. Senate and House of Representatives are also studying the prospects for using loan guaranties and their affect on various sectors within government and industry. The U.S. General Accounting Office is preparing a report to congress on government involvement in geothermal development. The GAO conducted a survey by sending questionnaires (Appendix A) to 180 federal and state leaseowners; approximately 62 percent of them responded. A GAO draft report should be ready by spring 1978 and a final report by Fall 1978 .

These sources and others that were consulted addressed the Geothermal Loan Guaranty Program directly, loan guaranties in general as a financing mechanism, the financial climate in the geothermal industry, other government supports, and geothermal development in the United States. All are referenced in the bibliography of this paper.

Study organization

This study begins with chapter II, an overview of the geothermal industry - the state of the art, and current and future potential, in order to give perspective to the scope of the problem of developing geothermal resources. 
Chapter III, "The Geothermal Loan Guaranty Program," focuses on the specifics of the program: applications received and pending, operating procedures, and the reviewing process. Legislative background sets the timeframe in which the program has evolved.

Chapter IV. "Externalities Affecting the Geothermal Loan Guaranty Program," lends insight to those factors impeding the development of the resource and the effectiveness of the loan guaranty program. Barriers, other than financial, that have prevented the industry from developing to a point where full advantage could be taken of such a program are evaluated.

Chapter V. "Evaluating the GLGP: Attitudes and Perspectives," elaborates the private sectors perceptions of the loan guaranty program. An understanding of how the program meets the needs and serves the purpose of lending institutions, private industry, and utilties is required to determine its potential capability. The existing problems for the use and operation of the loan guaranty program aid in evaluating its impact and are the basis for recommendations made in chapter VI.

The uncertainty and risk associated with geothermal resources with respect to the legal, institutional, and technical barriers are outside of the scope of this paper, 
except as they are an impediment to the functioning of the loan guaranty program. These subjects have been addressed in greater detail by others.

The geothermal industry and the government have traveled far up the "learning curve" in a matter of a few years. Growing pains are apparent in this "infant industry" but growth is taking place, regardless of the status of the Ioan guaranty program. It is the hope of the author that information provided herein will aid in furthering the understanding of the magnitude, complexities, and interdependencies of constraints affecting the geothermal industry. 


\section{STATE OF THE ART -- GEOTHERMAL ENERGY OVERVIEW}

Geothermal resources were used for the generation of electricity first at Laradello, Italy in 1904; $250 \mathrm{kilo-}$ watts were being generated by 1931. Italy presently produces 417 MW of electricity. In 1958, New Zealand was the second country to generate electricity using geothermal resources, with current production of about $170 \mathrm{MW}$. The United States was the third country to produce electricity, beginning in 1960 at the Geysers. Presently, several countries are exploring for and utilizing geothermal resources for non-electric uses and for generating electricity: Iceland, Hungary, USSR, Japan, Mexico, Honduras, El Salvador, Nicaragua, and several others (Table 1).

The United States is the world's largest producer of electricity utilizing a vapor-dominated hydrothermal (dry steam) resource. The only geothermal power plant generating electricity, at the Geysers in california, currently produces 502 MW of electricity with plans to generate an additional $626 \mathrm{MW}$ by 1981 (Table 2). Total potential for this area has been estimated to be 2000-2500 MW. 
Table 1

Worldwide Approximate Electric and Non-Electric Use of Geothermal Energy, 1976

\begin{tabular}{|c|c|c|c|}
\hline Country & $\begin{array}{l}\text { Operating } \\
\text { Operating }\end{array}$ & $\begin{array}{r}\text { Power (MW) } \\
\text { Planned } \\
\end{array}$ & $\begin{array}{l}\text { Non-Electric } \\
(\mathrm{MW})\end{array}$ \\
\hline Hungary & -- & -- & 380 \\
\hline Iceland & 3 & 55 & 285 \\
\hline Italy & 417 & 15 & 15 \\
\hline Japan & 170 & -- & 25 \\
\hline Mexico & 75 & 75 & -- \\
\hline New Zealand & 170 & 210 & 120 \\
\hline United States & 502 & 626 & 15 \\
\hline U.S.S.R. & 6 & 20 & 5,100 \\
\hline El Salvador & 30 & 30 & $=-$ \\
\hline Guadaloupe & -- & 30 & -- \\
\hline Turkey & -- & 10 & -- \\
\hline Nicaragua & -- & 100 & -- \\
\hline Total & 1,373 & 1,171 & 5,940 \\
\hline
\end{tabular}

Based on data provided from: Birsic, 1976 and Howard, 1975 (cited in Sacarto, pg. 3) 
Table 2

Existing and Expected Capacity at the Geysers Geothermal Power plants

\begin{tabular}{|c|c|c|c|c|c|c|}
\hline \multirow[b]{2}{*}{ Unit } & \multirow[b]{2}{*}{ Year } & \multirow{2}{*}{$\frac{\text { Capacity }}{\mathrm{Net}_{\mathrm{KW}}}$} & \multirow[b]{2}{*}{ Cum. } & \multicolumn{2}{|c|}{ Capital Cost } & \multirow[b]{2}{*}{$\begin{array}{c}\text { Steam } \\
\text { Producer } \\
\end{array}$} \\
\hline & & & & Esit $\$(000$ Total & $\begin{array}{l}\text { Per } \\
\mathrm{KW} \$ \\
\end{array}$ & \\
\hline 1 & 1960 & 11,000 & 11 & 1,750 & 159 & $\mathrm{U}-\mathrm{M}-\mathrm{T}$ \\
\hline 2 & 1963 & 13,000 & 24 & 2,200 & 169 & $U-M-T$ \\
\hline 3 & 1967 & 27,000 & 51 & 3,790 & 140 & $\mathrm{U}-\mathrm{M}-\mathrm{T}$ \\
\hline 4 & 1968 & 27,000 & 78 & 3,170 & 117 & $\mathrm{U}-\mathrm{M}-\mathrm{T}$ \\
\hline 5 & 1971 & 53,000 & ) & & & $U-M-T$ \\
\hline 6 & 1971 & 53,000 & 184) & 11,500 & 108 & $\mathrm{U}-\mathrm{M}-\mathrm{T}$ \\
\hline 7 & 1972 & 53,000 & ) & & & $U-M-T$ \\
\hline 8 & 1972 & 53,000 & 290) & 11,900 & 112 & $U-M-T$ \\
\hline 9 & 1973 & 53,000 & ) & & & $\mathrm{U}-\mathrm{M}-\mathrm{T}$ \\
\hline 10 & 1973 & 53,000 & $396)$ & 13,500 & 127 & $\mathrm{U}-\mathrm{M}-\mathrm{T}$ \\
\hline 11 & 1975 & 106,000 & 502 & 14,404 & 136 & $U-M-T$ \\
\hline $12(\mathrm{C})$ & July/78 & 106,000 & 608 & 21,500 & 203 & $U-M-T$ \\
\hline $13(\mathrm{C})$ & July/79 & 135,000 & 743 & 28,900 & 214 & $\begin{array}{r}\text { Burmah } \\
\text { (Aminoil) }\end{array}$ \\
\hline $14(\mathrm{C})$ & Feb/79 & 110,000 & 853 & 28,000 & 255 & $\mathrm{U}-\mathrm{M}-\mathrm{T}$ \\
\hline $15(\mathrm{C})$ & Sept/78 & 55,000 & 908 & 17,300 & 315 & Thermogenics \\
\hline $16(\mathrm{P})$ & May/81 & 110,000 & 1,018 & 42,400 & 385 & \\
\hline $17(\mathrm{P})$ & May/81 & 110,000 & 1,128 & 41,600 & 378 & \\
\hline $\begin{array}{l}\text { C-und } \\
\text { P-plat } \\
\text { U-Uni } \\
\text { M-Magi } \\
\text { T-The }\end{array}$ & $\begin{array}{l}\text { constru } \\
\text { sed, gove } \\
\text { oil Co. } \\
\text { a Power } \\
\text { nal power }\end{array}$ & $\begin{array}{l}\text { tion } \\
\text { nment apl }\end{array}$ & als pe & nding & & \\
\hline
\end{tabular}

Source: Birsic, 1976; Pacific Gas and Electric and Union Oil Company, Promotional Material, 1976. 
Resource Potential

Electric generating potential from hydrothermal convection systems (6) and geopressured sedimentary environments (7), assumed recoverable with present and near-current technology and without regard to cost, are presented in Tables 3 and 4 . Electric potential from hydrothermal reserves is $3,500 \mathrm{MW} \cdot \mathrm{cent}$ or 11,700 MW for 30 years, with an equal amount from paramarginal resources. Undiscovered hydrothermal $\left(>150^{\circ} \mathrm{C}\right)$ resources are estimated to have a potential, assuming 60 percent recoverable at prices $2 \mathrm{X}$ present prices, of $38,000 \mathrm{MW} \cdot \operatorname{cent}(126,700 \mathrm{MW}$ for 30 years). Geopressured fluids of the Gulf coast range in potential from 9,000 to $35,000 \mathrm{MW} \cdot$ cent $(31,000$ to $115,000 \mathrm{MW}$ for 30 years) depending on factors of production (excluding methane gas). Production potential from identified hydrothermal and geopressured systems, disregarding cost, with present or near present technology is estimated to be about $42,000 \mathrm{MW} \cdot \mathrm{cent}$ (140,000 MW for 30 years) (USGS CI 726, pg. 155).

Hot dry rock, methane gas from geopressured resources, and yet undiscovered hydrothermal convection systems will be of significant contribution to the national energy needs. USGS

\footnotetext{
${ }^{(6)}$ Heat is transferred by convection circulation of water or steam rather than by thermal conduction through solid rock (CI 726, p. 5).

(7) Deposition of fluids under abnormally high pressures in sediments.
} 
Table 3

Geothermal Resources of Hydrothermal Convection Systems

$10^{18} \mathrm{cal} 1 / \quad \begin{gathered}\text { Electrical } \\ \text { energy } \\ \text { MW cent } / 30 \text { years }\end{gathered}$

High-temperature systems

(>150 $\mathrm{C}$; for generation

of electricityl

Identified resources

257

Reserves ?/

3,500

11,700

Paramarginal resources 8/

3.500

11,700

Submarginal resources $9 /$

$>1,0004 /$

$>3,3004 /$

Undiscovered resources

1,200

$38,000 \underline{5}$

$126,700 \underline{5 /}$

Intermediate-temperature

systems $190^{\circ}$ to $150^{\circ} \mathrm{C}$ :

mainly non-electrical

uses).

Identified resources

Undiscovered resources

$\underline{1,035}$

TOTAL

2,837

46,000

153,400

1/ $10^{18} \mathrm{cal}$ (a billion-billion calories) is equivalent to heat of combustion of 690 million barrels of oil or 154 million short tons of coal; these estimates exclude the national parks.

2/ Unit of electrical energy; $1 \mathrm{MW} \cdot c e n t$ is equivalent to $1000 \mathrm{KW}$ produced continuously for 100 years.

3/ Assumes that each MW-cent of electricity can be produced at rate of 3.33 MW for 30 years.

4/ Small because of exclusion of systems with temperatures below $150^{\circ} \mathrm{C}$.

5/ Perhaps as much as 60 percent will be reserves and paramarginal resources; costs of discovery and development are more speculative than for identified resources.

6/ Reserves: recoverable with present technology and competitive cost.

7/ Paramarginal: recoverable with one to two times current energy costs.

8/ Submarginal: recoverable at greater than two times current prices of competitive energy sources.

Source: U.S.G.S. CI 726, P. 150 . 


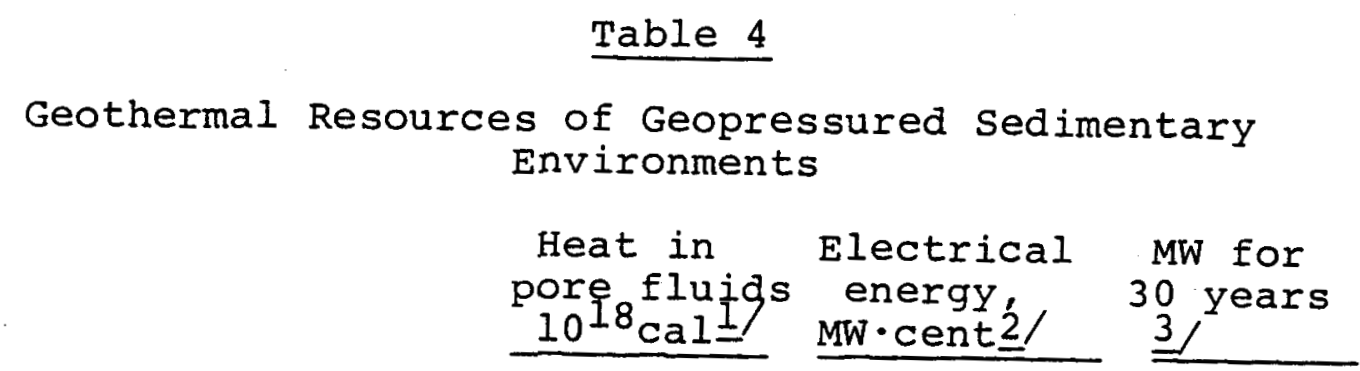

Gulf Coast geopressured

fluids in sediments of Tertiary age; assessed on-shore parts only, to depth ranging up to

$7 \mathrm{~km}$.

10,920

Thermal energy

24,380

81,260

Mechanical energy

(thermal equivalent)

$\frac{9,970}{34,350 \text { 4/ }} \frac{33,230}{114,490 \text { 4/ }}$

TOTAL

If Thermal energy only; $10^{18} \mathrm{cal}$ is equivalent to heat of combustion of 690 million barrels of oil.

2/ Units of electrical energy; $1 \mathrm{MW} \cdot$ cent is equivalent to $1000 \mathrm{kw}$ produced continuously for 100 years.

3/ Estimates made for $20 \mathrm{yr}$. production period; converted to 30 yrs. to be consistent with other estimates of this circular.

4/ Perhaps in part reserves but mostly paramarginal, depending on environmental and other costs.

Source: U.S.G.S. CI 726, p. 151. 
estimates potential for these resources to be at least 100,000 MW. cent (or 330,000 MW for 30 years).

Leasing

Leasing activity on federal land was supposed to have been spurred on with enactment of the Geothermal steam Act of 1970 (P.L. 91-581); however, several problems have dampened this effort. Regulations for the implementation of the leasing program were not completed until December 1973 and the first lease sale was in January 1974.

The Bureau of Land Management (Dept. of Interior) was designated the lead agency, working with the U.S. Dept. of Agriculture (Forest Service) to issue competitive lease sales for KGRA's (Known Geothermal Resource Areas) and noncompetitive lease applications for land authorized for geothermal exploration but not designated as KGRA's.

The competitive lease sales are made by bonus bidding-the lease is sold to the highest qualified bidder. A corporation established to do business in the U.S. or an individual can bid on a lease.

The U.S. Geological Survey has identified 106 KGRA's in a total area of greater than 3.3 million acres. These are listed in Appendix B.

Since January 1974 and as of January 30, 1978 federal leasing activity has been as follows: 178 competitive leases 
totaling 349,659 acres and 1,024 non-competitive leases totaling $1,673,505$ acres were issued (Bureau of Land Management, oral communication).

of the 3.3 million acres located in 10 western states and Alaska designated KGRA's, 1 million acres are on Federal land. An additional 96 million acres are listed as having potential value for geothermal resources; of these, 58 million acres (60 percent) are on Federal land. Only 10.5 percent of all KGRA's and only 3 percent of federal lands authorized for geothermal exploration have been leased. Many firms conduct some exploration before leasing but these efforts are not impressive with respect to the potential development of geothermal resources.

Private land is also leased for geothermal exploration and development. The extent of private leasing activity is difficult to monitor but is thought to be more extensive than leasing of state and federal lands partially due to the delays and paperwork involved in federal ieasing procedures.

Several major oil companies are active in geothermal leasing and development. Appendix C presents competitive lease sales as of December 31,1977 , and is also a good indication of which firms are involved in geothermal leasing and the competition for leases. 
Drilling Activity

Drilling is an expensive venture and capital must be available in order to locate additional geothermal reserves. Table 5 represents typical drilling costs.

Drilling activity for geothermal resources has not been significant compared to the number of oil and gas wells drilled in the United States. The majority of all geothermal wells have been drilled at the Geysers. The Imperial Valley is the only other area with significant drilling activity. Table 6 represents the number of geothermal wells drilled in 1975, 1976, and 1977. Appendix D lists drilling by operator and location. Drilling, together with leasing activities listed by operator indicates those most active in exploring and developing geothermal resources.

Table 6

Geothermal Wells Drilled in the United States, 1975-77

\begin{tabular}{|c|c|c|c|c|}
\hline Year & Geysers & $\begin{array}{c}\text { Imperial } \\
\text { Valley } \\
\end{array}$ & $\begin{array}{l}\text { Other } \\
\text { Locations }\end{array}$ & Total \\
\hline 1975 & 24 & 10 & 18 & 52 \\
\hline 1976 & 30 & 16 & 19 & 65 \\
\hline 1977 & 32 & 8 & 18 & 58 \\
\hline
\end{tabular}

Drilling taking place in states other than California includes New Mexico, Nevada, Utah, Idaho, Oregon, and Hawaii. 
Table 5

Drilling Costs for Geothermal Wells

\begin{tabular}{|c|c|c|c|c|}
\hline Depth (KM) & Total Cost & $\begin{array}{c}\text { Average } \\
\text { Cost/Meter } \\
\end{array}$ & $\begin{array}{c}\text { Marginal } \\
\text { Cost/Meter } \\
\end{array}$ & Source \\
\hline 0.5 & 50,000 & 100 & 100 & Meidav \\
\hline 1.0 & $\begin{array}{l}150,000 \\
150,000\end{array}$ & $\begin{array}{l}150 \\
150\end{array}$ & 200 & $\begin{array}{l}\text { Meidav } \\
\text { USGS }\end{array}$ \\
\hline 2.0 & $\begin{array}{r}420,000 \\
300,000 \\
300-520,000\end{array}$ & $\begin{array}{r}210 \\
150 \\
166-216\end{array}$ & $\begin{array}{l}270 \\
150\end{array}$ & $\begin{array}{l}\text { Meidav } \\
\text { USGS } \\
\text { Rex }\end{array}$ \\
\hline 3.0 & $\begin{array}{r}810,000 \\
500,000 \\
425-770,000\end{array}$ & $\begin{array}{r}270 \\
167 \\
170-260\end{array}$ & $\begin{array}{l}390 \\
200 \\
250\end{array}$ & $\begin{array}{l}\text { Meidav } \\
\text { USGS } \\
\text { Rex }\end{array}$ \\
\hline 5.0 & $\begin{array}{r}1,000,000 \\
635,000-1,055,000\end{array}$ & $\begin{array}{r}200 \\
200-230\end{array}$ & $\begin{array}{l}250 \\
250\end{array}$ & $\begin{array}{l}\text { USGS } \\
\text { Rex }\end{array}$ \\
\hline 10.0 & $\begin{array}{l}5,000,000 \\
2,750,000\end{array}$ & $\begin{array}{l}500 \\
300\end{array}$ & $\begin{array}{l}800 \\
340\end{array}$ & $\begin{array}{l}\text { USGS } \\
\text { Rex }\end{array}$ \\
\hline
\end{tabular}

Source: Sacarto, State Policies for Geothermal Development, 1976, p. 25 . 
These figures are not significant if $20,000 \mathrm{MW}$ is expected to be generated by the year 2000. Problems associated with drilling activity are dealt with in Chapter III.

Status of Geothermal Prospects

Presented here is the current status of six principal geothermal areas and the potential development associated with each. Figure 1 presents the location of these and other areas undergoing various phases of development.

The only power plant in operation is at the Geysers in California. The eleven power plants mentioned here, in planning stages, should generate an additional 435 MW (excluding the Geysers); six of the eleven potential power plants would be financed with federal loan guaranties and two are candidates for the government cost-shared demonstration plant.

\section{Geysers}

1) Pacific Gas and Electric Company owns the power generating units. Union Oil is the operator, Thermal Power Co., Magma Power Co., Aminoil, and Thermogenics, Inc., are steam suppliers. Current power is $502 \mathrm{MW}$, with an additional 626 MW planned.

2) The California State Department of Water Resources plans to build a $55 \mathrm{MW}$ power plant to be operating by 1983 . An estimated $\$ 25$ million will be spent on construction. McCulloch Oil Co. will supply the steam earning working 
Figure 1. Geothermal Resources Development.

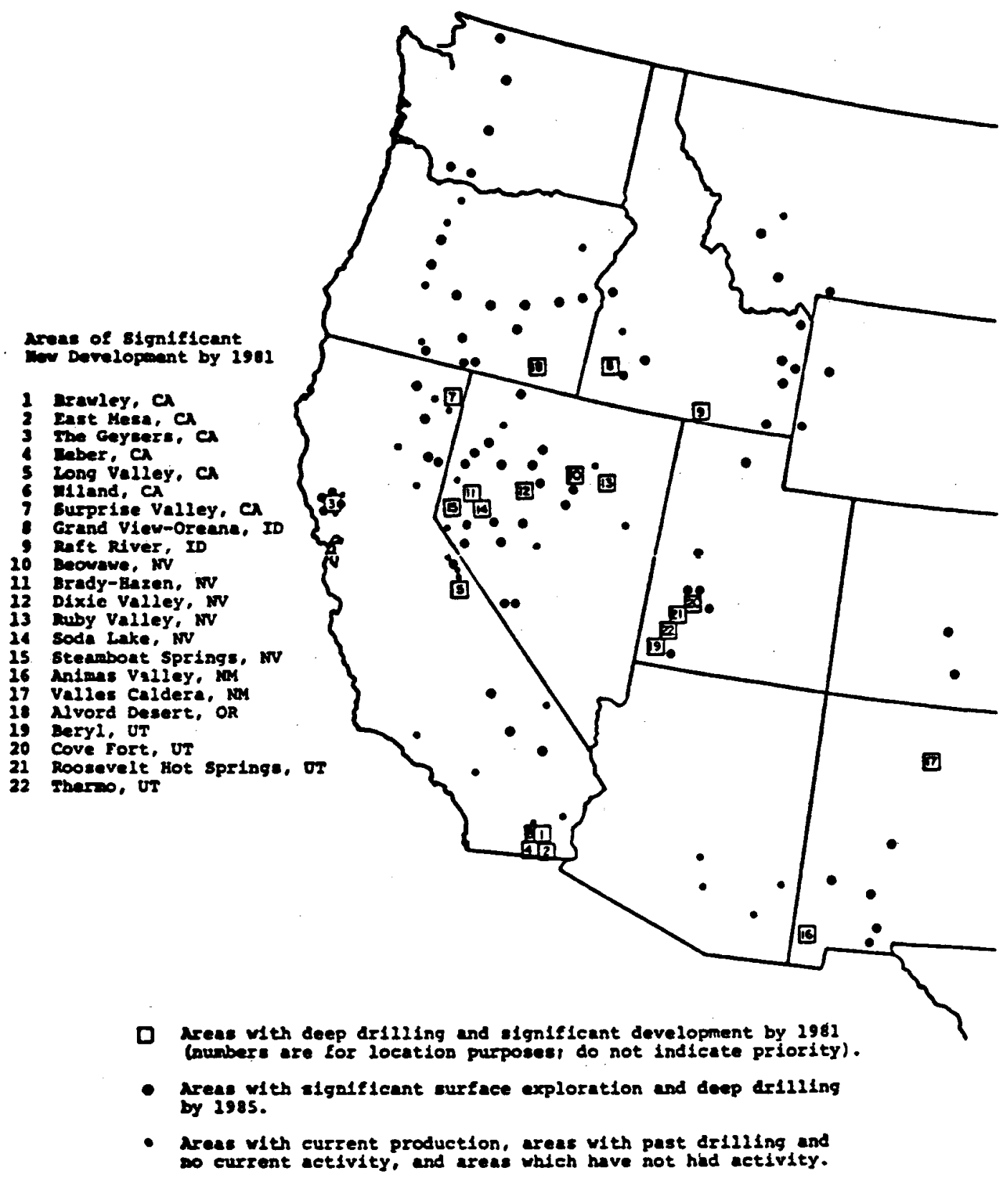

Source: U.S. Fish and Wildlife Service, Department of Interior, Geothermal Project, 1976. 
interest revenues of 49 percent, with Geothermal Kinetics, Inc., receiving 30 percent and Entex Petroleum 21 percent. Financing will be via conventional means, e.g. revenue bonds (The Geysers, 1977).

3) The Northern California Power Agency has contracted with Shell oil to supply steam for a 55 MW power plant. This is pending financing with a federal loan guaranty and negotiating a contract with Pacific Gas and Electric to transmit the electricity.

II. Imperial Valley, California

East Mesa

4) Magma Power Company (Imperial Magma) is constructing a 10 MW binary cycle ${ }^{(8)}$ power plant, operation to begin in August, 1978 .

5) Republic Geothermal, Inc. is doing field development work with a federal loan guaranty and plans to construct a double flash(9) 48 MW power plant.

Brawley

6) Union oil Company has obtained a permit. to construct a 10 MW single flash power plant. Possibly Southern California

(8) Binary cycle: use of a heat exchanger to conduct heat from a geothermal brine to the working fluid (isobutane) which drives a turbine.

(9) Single or double flash: steam produced from hot water due to a decrease in pressure. 
Edison or the Imperial Irrigation District will purchase electricity. Principal operators at Brawley are Union and Chevron.

Heber

7) San Diego Gas and Electric has submitted a proposal to DOE for the demonstration Program Opportunity Notice (PON) for a 50-MW binary cycle power plant costing about $\$ 42$ million. Chevron, Magma, Union, and New Albion Resources Company (NARCO), a subsidiary of SDG\&E are principal leaseholders at Heber.

Salton Sea

8) DOE and SDG\&E have a cost sharing agreement that funded the construction of a 10-MW binary cycle Geothermal Loop Experimental Facility--in operation since May 1976. Principal operators are Magma Power Co., Southern Pacific Land Co., and Southern California Edison. A 50-MW flash binary power plant is under consideration.

\section{Westmoreland}

9) Republic Geothermal and Mapco jointly lease and operate this prospect. An application for a federal loan guaranty has been submitted for reservoir assessment and drilling. A 50-MW double-flash power plant is planned.

\section{Desert Peak (Brady-Hazen), Nevada}

10) Phillips Petroleum is the principal operator. Sierra Pacific is interested in purchasing electricity at the busbar. 
A 50 MW double flash power plant is under consideration. The Geothermal Energy Corporation and Morrison-Knudsen are involved in the negotiations; submission of an application for a loan guaranty is pending.

IV. Beowawe, Nevada

Chevron and Chevron/American Thermal are the principal operators. Sierra Pacific had spent some $\$ 300,000$ without success. The operators plan for extensive exploration.

V. Roosevelt Hot Springs, Utah

Principal operators are Phillips Petroleum and Thermal Power Co.

11) Rogers Engineering is submitting an application for a federal loan guaranty for construction of a 52 MW double flash power plant at a cost of about $\$ 35$ million. Utah Power and Light will purchase the electricity and Phillips Petroleum will supply the resource.

12) O'Brien Resources, together with VTN, Thermal Power Company, and AMAX Exploration are submitting an application for a federal loan guaranty to drill 8-9 wells, including 3 reinjectors, and construction of a $55 \mathrm{MW}$ double flash power plant. Negotiations are underway to sell electricity to the city of Bountiful. 
VI. Valles Caldera, New Mexico

13) The principal operator is Union Oil Co. Union has submitted a proposal to the Department of Energy for the construction of a $50 \mathrm{MW}$ flash demonstration plant in response to the PON. The Public service Company of New Mexico is the utility involved in this venture.

Many other areas are being explored for geothermal resources and development: a) Cove-Fort Sulphurdale, UtahUnion, b) Coso Hot Springs, California, China Lake, Naval Weapons Center has requested proposals and is looking for a developer. c) Becwawe, Nevada - extensive exploration by Chevron oil Company, d) Raft River, Idaho - Department of Energy, binary cycle power plant, e) Los Alamos Scientific Laboratory, New Mexico - Hot Dry Rock Geothermal Energy Project funded since 1970 ; drilled into $200^{\circ} \mathrm{C}$ granite to $3 \mathrm{KM}$. A $10 \mathrm{MW}$ (thermal) binary cycle power plant is planned, f) Hawaiian Islands- exploratory drilling in Kilauea and Puna. Geopressured resource potential and feasibility are being studied extensively at the University of Texas, Bureau of Economic Geology, which was awarded $\$ 17$ million in grants from the Department of Energy.

Non-electric Utilization

Significant thermal resources, $700 \mathrm{MW}_{\mathrm{t}}$ worldwide (Lund, OIT), are available for direct application, including space 
heating, crop drying, industrial processing, sugar refining, fisheries, agribusiness, hydroponics, greenhouse complexes, pulp and paper processing, absorption - refrigeration, amonia synthesis, and chemical extraction. Space heating utilizes low enthalpy hydrothermal convection systems of temperatures $65-100^{\circ} \mathrm{C}$. Transmission distance of 50-100 km has been calculated and a $20 \mathrm{~km}$ distance is in use presently. Direct use offers high conversion efficiency of 80-90 percent, technology is presently available, and direct use costs are 60-75 percent of the fossil fuel costs, payback is 5 to 10 years (Geothermal Resources Council Symposium, 1978).

The possibility of using spent geothermal resources from electric generation for a secondary use can be a contribution to increasing efficiency and decreasing costs. The rate of return for direct use is lower than for electric use but the payout is faster and capital investment is not extensive. Klamath Falls, Oregon, Pagosa Springs, Colorado, and Boise, Idaho use their geothermal resources for extensive municipal and private residence space heating with plans for expansion. Currently, industries are utilizing geothermal resources for food processing, fisheries, hydroponics, greenhouse complexes, but it is insignificant in comparison to the potential use.

Figure 2 indicates some of the uses and their corresponding temperatures for nonelectric application of geothermal fluids. 


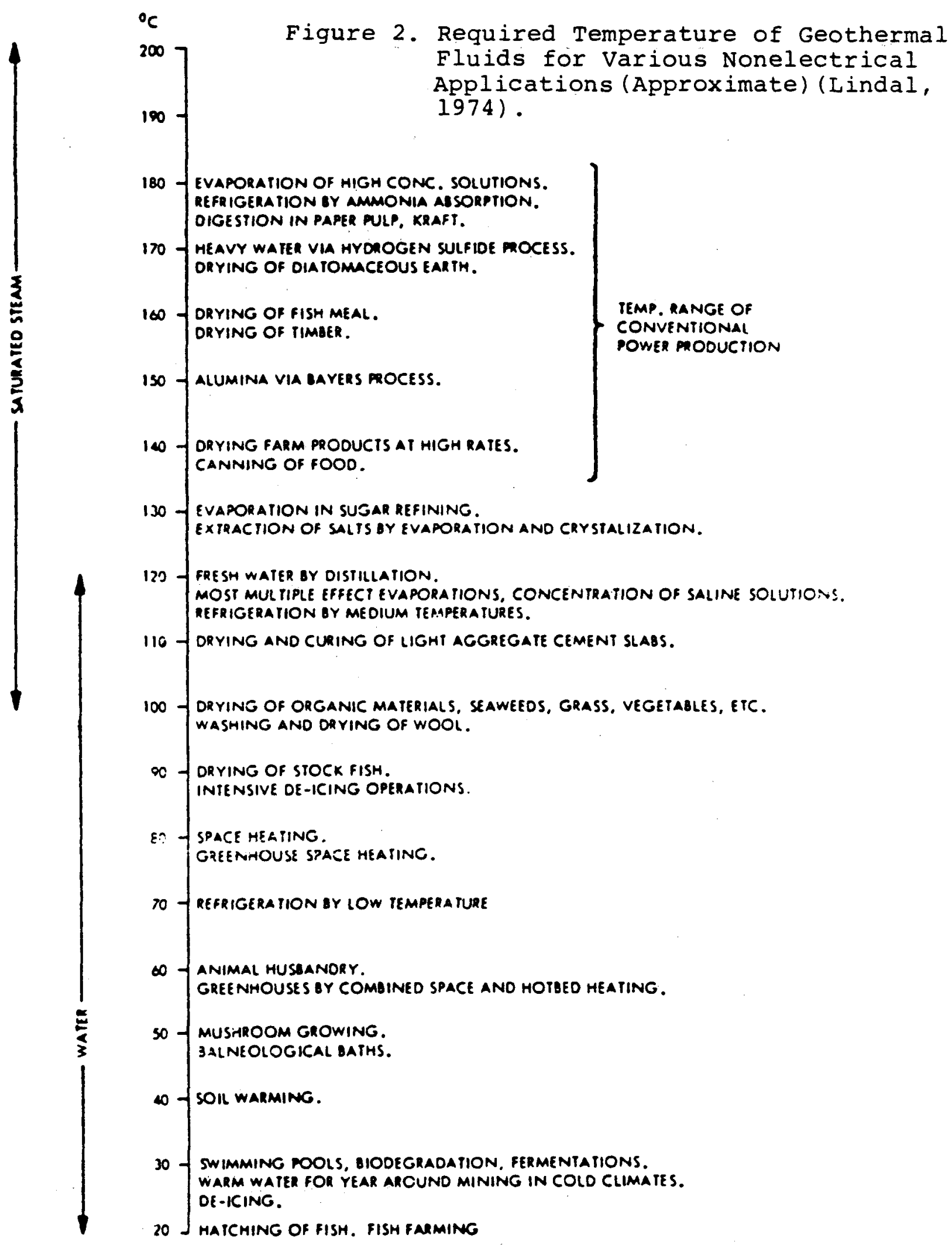

Source: Geothermal Resources Council, Direct Utilization Symposium, 1978. 
Industry structure

The geothermal industry is fairly new and most firms began their industry involvement 5 to 7 years ago. The industry is relatively small, with major developments involving a few firms. Reviewing leasing and arilling activity provides a good indication of which firms are more active. These are listed in Appendix E. Planned power plant construction, as outlined in the previous section, indicates Chevron, Phillips, Magma, and Union to be leading the way. Other projects involving field development, resource supply contracts, and potential construction of power plants involve Shell, Amax, Mapco, Thermal Power, Thermogenics, Republic Geothermal, Geothermal Kinetics, Geothermal Resources International, McCulloch Oil, Aminoil, and Phillips Petroleum.

Utilities, engineering firms, land ventures, and municipalities are also involved in several stages of geothermal resource development. Table 7 lists these firms and the various stages of development in which they are most likely to participate.

There are basically four areas the industry is directed towards:

1) Land acquisition:
a) federal - state
b) private

2) Exploration:
a) initial exploration - geological and geo- physical surveying. May precede lease acquisition. 


\section{Table 7}

Types of Firms and Involvement in Geothermal Development

Lease Field Power Plant Acquisition Exploration Development Construction

Oil

Companies

(1)

x

$\mathbf{x}$

$\mathbf{x}$

Geothermal

firms $(1,2)$

$\mathbf{x}$

$\mathbf{x}$

$\mathbf{x}$

0

Engineering

firms

Municipalities

(3)

$\mathbf{x}$

$x$

$\mathrm{x}$

0

Utilities

(3)

$\mathbf{x}$

$\mathbf{x}$

$\mathrm{x}$

x

(1) sell resource;

(2) sell electricity;

(3) transmit electricity.

$x$-probable

0 -possible 
b) exploration drilling - thermal gradient holes, observatory wells, deep wells.

3) Full field development:

Drilling production and injection wells.

4) Utilization of the resource:

a) generation of electricity

b) direct-use (nonelectric)

A firm or an individual acquires a lease and has several options depending on the objectives of the firm, value of the lease, and the type of organization. Leaseowners will try to increase the value of the lease by doing exploratory work and/or drilling to prove up a resource. A lease may then be sold to a developer who will engage in field development and either sell the resource to another party or the developer may engage in the construction of a power plant and sell the electricity to a utility, or engage in a joint venture with a utility who will build a power plant.

The experience in geothermal is similar to that in oil and gas: small independent firms are doing the exploration and the larger firms with better access to capital are developing the field. Several small firms are engaging in promoting resource utilization by joint venturing with resource owners, engineering firms, operators, leaseowners, utilities, and municipalities. Arrangements have been made whereby a resource owner contracts to supply steam to a power plant facility at 
a specified price and a utility purchases the electricity and most probably will option to purchase the power plant after several years of proven feasibility. The question remains as to whom will pay for the power plant. The developer is willing to finance the development of the field but neitherhe nor the utility companies, for various reasons (capital requirements, reservoir uncertainties, and regulatory issues) have been willing to finance liquid-dominated power plant construction. Several small independent firms are willing to act on behalf of a utility and resource supplier and apply for a loan guaranty to finance this construction.

\section{Financial Arrangements}

Financing for geothermal development is made available by the same mechanisms as in other resource investment oppotunities. Raising capital for geothermal ventures differs in that the-resource is unconventional, expensive to exploit, and involves a high level of risk. The payout is longer than for oil and gas, and many uncertainties including tax treatment make financing more difficult.

Geothermal investments are judged by the same criteria as other natural resources but may be viewed more critically and a higher rate of return may be required due to higher risks. Geothermal projects must compete for capital in a thin market, and with other investments of large integrated 
firms. ${ }^{(10)}$ The considerations for investment may be: undiluted interest to retain full control, cost of capital, and minimization of front end exposure.

Oil companies and other well-established industries, geothermal enterprises, municipalities, and utilities have different means of raising capital. Large established firms may sell securities to raise capital or use internally generated funds from other investments. Commercial banks will lend money to these firms at prime interest rates and generally they have little problem of financing. Smaller firms will seek capital through joint ventures with the larger firms, selling limited partnerships, or the venture capital market. A leaseowner or small "independent" may joint venture with a developer who has available capital. Drilling programs are a source for raising high risk capital. The limited partnership is used widely in the geothermal industry because it provides the operator with control and limits the liability of the limited partners to the amount of the investment and allows for attractive tax consequences. Table 8 identifies the sources of capital for different types of firms.

10) The University of Pennsylvania, Energy center, is under contract to the Division of Geothermal Energy, DOE, to study investment decisions for geothermal resources. 


\section{Table 8}

Capital Formation for Geothermal Projects

$\begin{array}{ll}\text { Large } & \text {; internal cash flows } \\ \text { established } & \text {, commercial lenders } \\ \text { firms } & \text {, securitieg offerings } \\ \text { e.g. } & \text {, joint ventures-land, drilling, federal } \\ \text { oil comp. } & \text {; venture capital - government } \\ \text { small } & \text { joint ventures - general partnership } \\ \text { firms } & \text {, fimited partnership } \\ \text { e.g. lease } & \text { federal government } \\ \text { exploration } & \text { federal } \\ \text { Municipalities } & \begin{array}{l}\text { revenue bonds } \\ \text { federal government }\end{array} \\ \text { Utilities } & \text { - revenue bonds } \\ & \text { federal government }\end{array}$

Government and Geothermal Development

The federal governments expectations for the development of domestic geothermal resources are shown in Tables 9 and 10. Potential electricity production from geothermal resources according to ERDA is 3000-4000 MW by 1985. The expected estimated utilization of the resource has undergone change from 1975 to 1977.

Table 10 was published a little more than a year after Table 9, at which time the figure for electrical generation was halved. The estimate is qualified by the assumption that federal program implementation is "successful." Many people in the geothermal industry have doubts of 3000-4000 MW generating by 1985. PG\&E at the Geysers, as planned, will 


\section{Table 9}

Estimated Geothermal Utilization Given Successful Federal Program Implementation*

\begin{tabular}{|c|c|c|c|}
\hline & 1985 & 2000 & 2020 \\
\hline Electric Capacity (MW) & 6,000 & 39,000 & 140,000 \\
\hline $\begin{array}{l}\text { Electric Applications } \\
\text { Equivalent Energy } \\
\text { (Quads/yr) }\end{array}$ & 0.5 & 2.9 & 10.4 \\
\hline $\begin{array}{l}\text { Nonelectric Applications } \\
\text { (Quads/yr) }\end{array}$ & 0.1 & 1.5 & 8.2 \\
\hline $\begin{array}{l}\text { Total Energy } \\
\text { (Quads/yr) }\end{array}$ & 0.6 & 4.4 & 18.6 \\
\hline
\end{tabular}

*Assuming $-1 \mathrm{MW}$ hr $-10^{7}$ Btu 85 percent load factor Source: Definition Report, DGE, ERDA, Oct. 1975.

Table 10

Intended Commercial Geothermal Utilization Potential Given Successful Federal Program Implementation

\begin{tabular}{|c|c|c|c|}
\hline & 1985 & 2000 & 2020 \\
\hline Electric Capacity (MW) & $\begin{array}{l}3,000- \\
4,000\end{array}$ & $\begin{array}{l}20,000- \\
40,000\end{array}$ & $\begin{array}{l}70,000- \\
140,000\end{array}$ \\
\hline \multicolumn{4}{|l|}{ Electric Applications } \\
\hline $\begin{array}{l}\text { Equivalent fossil fuel } \\
\text { energy (Quads/yr) }\end{array}$ & $0.2-0.3$ & $1.5-3.0$ & $5-10$ \\
\hline $\begin{array}{l}\text { Nonelectric applica- } \\
\text { tions (Quads/yr) }\end{array}$ & 0.1 & 1 & 8 \\
\hline $\begin{array}{l}\text { Total Energy } \\
\text { (Quads/yr) }\end{array}$ & $0.3-0.4$ & $2.5-4.0$ & $13-18$ \\
\hline Quad $=10^{15} \mathrm{Btu}$ & & & \\
\hline
\end{tabular}


have about $1125 \mathrm{MW}$ by 1981 and if the 11 power plant projects outlined in this report are completed, that will mean an additional 435 MW. Given the time constraints of drilling, permitting, construction, capital requirements, etc., one wonders where the additional 1500-2500 MW will come from. The government is spending millions of dollars on research and development of geothermal resources trying to realize the numbers they have forecasted. Projects have been undertaken, much of which have been contracted out to private industry, to address technological developments, resource assessment, policy and planning issues, institutional and legal barriers, and financial incentives.

The ERDA budgetary outlays for the geothermal research, development, and demonstration program for FY 1978 was $\$ 68$ million, an increase of $\$ 19$ million from FY 1977. Table 11 presents budget outlays and authority for geothermal energy from 1975 to 1979. Appendix F contains the entire ERDA budget for FY 76 through 1978 .

Legislation, cost sharing programs, tax incentives, and the loan guaranty program are efforts to promote exploration and development of geothermal resources. A survey of these programs is outlined herewith to present the extent and means of the programs in operation. 
Table 11

Federal Budget for Geothermal Energy 1975-1979

Budget outlays
(million $\$$ )

1975 (ERDA)

1976 (ERDA)

1977 (ERDA)
21

30

49

\author{
Budget \\ Authority \\ (million \$)
}

28

32

100

(50 GLGP)

1978 (DOE)

Total

93.5

$(6.6)$ GLGP

126.2

$(15.0)$

$(5.0)$ IDC

$\frac{(5.0)}{106.2}$

1979 (DOE)

$134.9 *$

$(6.0)$ GLGP

145.7 *

$(6.0)$

$(10.0)$ IDC

Total

118.9

$\frac{(10.0)}{129.7}$

Non-federal support

1975

10.7

10.9

1976

10.1

12.2

1977

5.8

5.9

* Excluding hydroelectric

GLGP - Geothermal Loan Guaranty Program

IDC - Expensing of intangible drilling cost

Note: Of the Department of Energy's first year budget, $\$ 10.4$ billion, about 6.5 percent is for geothermal energy.

Source: Office of Management Budget, 1978, oral communication. 
I. The Geothermal Loan Guaranty Program preceded the cost sharing programs. The GLGP less-than-successful history is often cited as reason for implementing additional programs. The Geothermal Loan Guaranty Program is described in detail in chapter III. In short, the government will guaranty 100 percent of a loan of up to 75 percent of total project costs. Limits of the guaranty are $\$ 100$ million per project and $\$ 200$ million per borrower.

II. The Geothermal Reservoir Case History Program, an "industry coupled" program, offers 30 to 50 percent of costs to purchase information regarding drillholes in geothermal areas. The purpose is to publish the information obtained, thereby improving availablity of technical information. The program's architects hope to reduce risk and thereby reduce costs of developing geothermal energy, and hope to stimulate exploratory drilling. Geophysical data, subsurface logging and coring data, flow and pressure test data will be obtained from the participants.

Request for Proposals (RFP) is the means of soliciting bids from industry to participate in the program. Six contracts have been awarded to the following firms: 
1) Union oil Company of Los Angeles, Calif. to drill, test, and provide data from three 10,000 foot holes in the Cove Fort-Sulphurdale, Utah area. Esțimated share by DOE: $\$ 2,560,000$ (The Geyser, Oct. 1977).

2) Getty oil Company of Bakersfield, Calif. to drill a 6,000 foot exploratory well at (South) Roosevelt Hot Springs, Utah. Estimated share by DOE: $\$ 396,000$ (The Geyser, Oct. 1977).

3) Geothermal Power Company of Novato, Calif., to drill 15 heat gradient holes 300 to 500 feet, drill two 2000 faet observation holes, and drill three exploratory wells up to 7,000 feet in the Roosevelt Hot Springs area (northeast), Utah. Estimated share by DOE: $\$ 710,500$ (The Geyser, Oct. 1977).

4) Thermal Power Company of San Francisco, Calif., to provide data on existing wells in the dome fault at Roosevelt Hot Springs, Utah. Estimated share by DOE: $\$ 282,000,20$ percent of Thermal's cost (The Geyser, Oct. 1977).

5) Seismic Exploration, Inc., of Salt Lake City, Utah, to obtain geophysical data north of the dome fault at Roosevelt Hot Springs, Utah. Estimated share by DOE: $\$ 11,740$ (The Geyser, Oct. 1977).

6) University of Denver, Denver, Colorado, to test and provide data from a two-phase flow in the wellbore on an existing well at Roosevelt Hot Springs, Utah. Estimated share by DOE: $\$ 67,330$ (The Geyser, Oct. 1977). 
Private industry has expressed concern in turning over proprietary information to the government. Several factors account for their concern: private industry-government relationship and economic effects. Industry is concerned with government's involvement in developing energy resources. It may also prove to be an economic disadvantage to some firms, while an economic advantage to others. For example, if two firms have adjacent leases and one finances exploration with private funds only while the other uses government assistance, the economics for the latter improve substantially. If several million dollars has been spent in an area by one leaseholder and information on the area is publicized by the government, the competitive advantage is lost. A company holds exploration data proprietary to gain advantage in purchasing future lease offerings. The Reservoir Case History Program may, therefore, inhibit exploration in areas where data will be made public. Several firms have expressed interest in this program in comparison to the loan guaranty program.

III. The Department of Energy has other cost sharing programs in electric and nonelectric utilization of geothermal resources. The Division of Geothermal Energy of the San Francisco Operations office has offered two Program Opportunity Notices (PON), and has plans for another PON in addition to two Program Research and Development Announcements 
(PRDAs) for site specific engineering and economic studies of nonelectric applications.

The first nonelectric PON was offered in 1977, with a closing date of November 30,1977 . A final decision granting eight contracts, out of a total of 22 proposals, was reached in February, 1978. Under ERDA, $\$ 1.5$ million was allocated for this PON. Several of the grants were for space heating projects and one was for retrofit of a food processing plant.

The Geothermal Demonstration Plant (PON) estimated cost by DOE to be $\$ 130$ to $\$ 150$ million. The DOE share is expected to be 50 percent or less of the estimated cost. The closing date for the Geothermal Demonstration Plant Program opportunity Notice was January 31, 1978. A decision is scheduled to be reached by september 30,1978 . The purpose is to support the design, construction, and demonstration of a power plant utilizing a liquid-dominated hydrothermal resource. It is hoped that the demonstration program will reduce reservoir uncertainty, demonstrate availability of the technology, and provide information on the performance and operation of the power plant and reservoir. ERDA proposed that the plant should be in operation by the end of 1982 and generate approximately $50 \mathrm{MW}$ net electric power.

The Demonstration Program has been the subject of great debate in government and industry. The proponents of the 
demonstration program feel that only a demonstration can provide the experience and data necessary to stimulate construction of power plants for utilization of geothermal resources. It is expectod to be in operation by 1982 . However, Magma Power Company expects to have its binary cycle power plant at East Mesa generating electricity in August, 1978 .

The MIT Energy Laboratory Policy Study group has addressed government intervention in developing new energy technologies and the issues of funding a demonstration plant.

The MIT study concludes that:

"In most cases, the long-run commercial potential of new technology, when evaluated prior to the introduction decision, will be independent of possible federal interventions in the introduction stage. In most cases, the costs of the introduction stage (which often is not recovered) during that stage, are a small fraction of the total cost of the product after introduction, if, when examined at the end of its development, a technology appears to be commercial in the long run, it usually is introduced and "commercialized" by the private sector (MIT, 1976, p. 72). In most cases FRDA demonstration programs, therefore, simply do not have very much leverage. They may be useful, but they are not often likely to be decisive in determining the fate of a new technology" (MIT, 1976, pg. 73).

"Thus, ERDA's commercial demonstration programs can be viewed somewhat crudely as subsidies or offsets to the 'introduction stage'--i.e., the excess of cost over production revenues during the introduction stage" (MIT, 1976, p. 73). 
It is important to mention the effect of such a program on normal investment decisions of private industry. A firm may decide not to invest or take the stand of "wait and see" if a project will potentially be subsidized by the government. If a firm can halve its cost of a commercial power plant by obtaining government subsidy, it is reasonable to believe the firm would prefer it; however, it is not to say that they would not have found other means to finance the project. A firm gains a competitive edge if it receives the subsidy. If such projects are only feasible with a subsidy, then the demonstration will do little to promote geothermal power plant construction even if it resolves technical uncertainties: unless it is believed that it is only those issues that are inhibiting the development.

Several problems associated with the resource and power plants arise out of the fact that each project is site specific. If the demonstration program can be at all successful, it must address geothermal fluids and geological areas that are diverse in nature. The current PON was directed at "a hightemperature, low-to-moderate-salinity resource with a binary or flashed steam power conversion cycle" (DGE Annual Report, April 1977, pg. 127). This does not eliminate technical problems associated with geology and geochemistry of fluids in other locations. The PON clearly states that current 
plans include only one demonstration plant but, according to government officials, they are considering funding a second demonstration plant. The controversy surrounding this program will continue for some time.

Another form of government incentives are tax treatments of geothermal resources: percentage depletion and write-offs of intangible drilling costs. Legislation is currently. pending to allow for these but it has been forthcoming for some time now. The geothermal industry feels very strongly about acquiring these tax deductions and that these will stimulate the industry.

Reservoir indemnity insurance, as an incentive to developing the geothermal industry, is a topic generating a lot of discussion. Members of the geothermal industry feel this could minimize the problem of the reservoir uncertainties of life and capability which they believe are the main obstacles to development. Legislation is being drafted to provide for reservoir indemnity insurance. At this time, it is difficult to determine whether or not this will become a reality.

In summary, little has been achieved in developing geothermal resources, in view of its large potential. 


\section{THE GEOTHERMAL LOAN GUARANTY PROGRAM}

Chapter III is devoted to the Geothermal Loan Guaranty Program and the specifics of its operation. Discussed are the objectives and purposes of the iegislation, budgetary allocation, expectations, operation and management of the program, processing and reviewing of applications, current status, and problems associated with the program.

\section{Legislation and Objectives}

The Geothermal Energy Research, Development, and Demonstration Act of 1974 (P.I. 93-410, Appendix G) was passed to facilitate in the development of geothermal resource potential. Title I of the Act established the Geothermal Energy Coordination and Management Project to conduct resource inventory and assessment, research and development, "initiate a program to design and construct geothermal demonstrations plants", and provide for scientific and technical education programs through the National science Foundation.

Title II provides for the establishment of a loan guaranty program, assistance in the payment of interest charges, and establishment of the Geothermal Resources Development Fund. 
Title III, General Provisions, states the requirements for carrying out the stated objectives of the Act.

The Law states that the purposes of the loan guaranty program are:

1. The determination and evaluation of the resource base (resource assessment),

2. research and development with respect to extraction and utilization technologies,

3. acquiring rights in geothermal resources (lease acquisition), and

4. development, construction, and operation of facilities for the demonstration or commercial production of energy from geothermal resources. Under the terms of the Act, loan guaranties will be granted for up to 75 percent of project costs with the federal government guarantying up to 100 percent of the amount borrowed; the applicant contributes 25 percent equity. The amount to be guaranteed is limited to $\$ 100 \mathrm{million}$ per project ard. $\$ 200$ million per borrower.

The life of the program is 10 years, to terminate on Sept. 3, 1984, but all loans guaranteed up to that time will be honored according to the terms of the loan agreement. The maximum term for any loan guaranty is 30 years or "the expected average useful life of any major physical asset to be financed by such loan, whichever is less," (\$790.6(h)) 
The loan guaranty program became effective June 25, 1976 as stated in the Rules and Regulations of the Federal Register of May 26, 1976 (10 CFR 790). See Appendix H.

As stated in the Rules and Regulations (10 CFR 790), the objectives of the loan guaranty program are:

1. To encourage and assist the private and public sectors to accelerate development of geothermal resources in an environmentally acceptable manner by minimizing a lender's financial risk.

2. To develop normal borrower-lender relationships in order that financing be made available without guaranties at some future time.

Priorities assigned to different types of projects are as follows :

1. Projects with promise of rapid energy production from geothermal resources.

2. Projects designed to demonstrate or utilize new technologies or produce advanced technology components.

3. Projects that will demonstrate or exploit the commercial potential of new geothermal resource areas.

4. Lowest priority is given to projects initially proposing geological and geophysical exploration, or the acquisition of land or leases. 
In addition, priority within each of these categories was given first to projects from which the Federal government receives royalty payments and second, to projects undertaken by small companies and private utilities.

A small utility is one whose total electric output did not exceed four million megawatt-hours; and, a small business is a concern independently owned and operated, is not dominant in its field of operation, does not have assets exceeding $\$ 9$ million, does not have net worth in excess of $\$ 4$ million, and does not have an average net income, after Federal income taxes, for the preceeding two years in excess of $\$ 400,000$ (average net income to be computed without benefit of any carryover loss). (\$790.5(i)\&(j)).

According to the Rules and Regulations, some entities are not eligible for obtaining a loan guaranty: 1) A loan application which meets a lender's standards without a Federal guaranty will be regarded by the Administration as not eligible for a loan guaranty under this regulation (\$790.4(c)). 2) Also ineligible are entities whose income is excluded from gross income for purposes of taxation as stated in Chapter I of the Internal Revenue Code of 1954. This would exclude publiclyowned electric utilities, including utilities owned by municipalities, and public utility districts. 3) a project for extraction or production of geothermal by-products or the disalination of geothermal brines is also ineligible. 
The "Technical Amendments to the Geothermal Energy Research, Development, and Demonstration Act," signed into law by President Carter on February 25, 1978 ameliorates several of the problems existing with the current law and regulation (see Appendix I for the text of these amendments).

The Amendments specifically address the inclusion of direct utilization of geothermal resources for new or existing facilities. In addition, it raises the maximum loan guaranty to $\$ 100$ million per project and $\$ 200$ million per borrower, pledges the "full faith and credit of the United States" to payment of the guaranties, establishes borrowing authority to meet default payments, and allows for interim payment of principal and interest to avoid default on worthwhile projects.

\section{Budgetary Allocations}

The Geothermal Resources Development Fund was set up to provide the necessary funds for carrying out the program, including any interestassistance to the applicants. There were no budgetary appropriations in FY 1976. The budgetary appropriations and dollars authorized to guaranty are as follows: 
Budget Appropriation

$$
\text { (millions of dollars) }
$$

FY77

FY78

Total
30

15

45
Loan Guaranties Budget Authorization (millions of dollars)

200

100

300

\$200 million was originally requested for FY78 but in light of the present status of the program, it was deemed unnecessary and an additional $\$ 100$ million was allowed. Currently there is about $\$ 286$ million authorized for guaranties. The decrease accounts for the 3 guaranties made for $\$ 13.644$ million.

A total amount of $\$ 300$ million is authorized for loan guaranties and $\$ 45$ million was appropriated for program costs including payment of interest, operating costs, and default payments. ERDA had requested backup funds in the ratio of 1 to 4 against the total expected amount of loan guaranties. This was reduced by the appropriations committee to 1:7. In other words, the amount of money appropriated will cover one failure for seven successful loans.

A detailed accounting of the Geothermal Resources Development Fund is provided in the Budget of the United States Government, Fiscal Year 1979, presented in Appendix J. 
Current Status of the Geothermal Loan Guaranty Program

As of February, 1978, one year and eight months after the program became effective, nine applications have been submitted for loan guaranties. SAN originally expected 17 to 20 applications during FY77 (Annual Report), but received only six. For FY78, the USGS was told to expect 10 applications for their review, although SAN has estimated that 2 to 4 applications for electric generation (application may be for exploratory drilling, field development, power plant construction), and 1 to 2 for nonelectric utilization, totaling a possible six applications. A FY79 budget request was based on the assumption of receiving 20 applications per year.

Table 12 is a summary of applications, including a list of those "currently being prepared." Most of these applications have not yet been submitted as scheduled, but it is not all inclusive, as some applicants do not appear on the list. A total of 28 applications were projected by SAN for 1978 according to the 1ist compiled in August, 1977. SAN now only expects a possible maximum of 10 applications in 1978 .

Table 13 is a breakdown of the nine applications submitted to SAN. Republic Geothermal Inc.(RGI), of Santa Fe Springs, California was the first to be granted a loan guaranty. The loan was for $\$ 9.03$ million to finance the drilling of 
Table 12

GEOTHERMAL LOAN GUARANTY PROGRAM APPLICATIONS

APPLICANT

\begin{tabular}{l} 
PROJECT \\
\hline Location
\end{tabular}

\begin{tabular}{ll} 
AMOUNT & \multicolumn{2}{c}{ EXPECTED DATE } \\
Sub- & $\begin{array}{l}\text { Recommen- } \\
\text { mission }\end{array}$
\end{tabular}

I. Applications Received

A. APPROVED

Republic Geothermal

East Mesa, CA

Brady Hot Springs, NV

Brawley, CA

Geothermal Kinetics/

McCulloch Oil Co.

B. AWAITING ADDITIONAL INFORMATION

Geothermal Resources

Geysers, CA

Geocal

Honey Lake, CA

City of Burbank

Multi-site

Diablo Exploration

New Mexico

RFL-NCPA

Geysers, CA

Westmorland, CA

C. BEING PROCESSED

RGI/MAPCO

\begin{tabular}{|c|c|c|c|}
\hline Electric & 9.03 & $10-76$ & Approved \\
\hline $\begin{array}{l}\text { Vegetable } \\
\text { Dehydration }\end{array}$ & 2.80 & $3-77$ & Approve \\
\hline Electric & 1.75 & $2-77$ & Approved \\
\hline
\end{tabular}

$\begin{array}{lcc}\text { Electric } & 7.7 & 10-76 \\ \text { Electric } & 2.27 & 10-76 \\ \text { Electric } & 25.0 & 3-77 \\ \text { Electric } & 21.8 & 3-77 \\ \text { Electric } & 14.5 & 9-77\end{array}$

Electric $\quad 21.0 \quad 9-77$ 
II. APPLICATIONS CURRENTLY BEING PREPARED

\begin{tabular}{|c|c|c|c|c|c|}
\hline \multirow{2}{*}{ APPLICANT } & \multirow{2}{*}{\multicolumn{2}{|c|}{ PROJECT }} & \multirow[b]{2}{*}{$\begin{array}{l}\text { AMOUNT } \\
\text { (SM) }\end{array}$} & \multirow[b]{2}{*}{$\begin{array}{l}\text { Sub- } \\
\text { mission }\end{array}$} & \multirow[b]{2}{*}{$\begin{array}{c}\text { Recommen- } \\
\text { dation }\end{array}$} \\
\hline & & & & & \\
\hline VTN & New Mexico & Power Plant & 6.0 & $2-78$ & $5-78$ \\
\hline Geothermal Power Company & Utah & Electric & 7.0 & $3-78$ & $6-78$ \\
\hline O'Brien Energy & Milford, UT & Electric & 25.0 & $1-78$ & $4-78$ \\
\hline U.S. Geothermal & Broneau, ID & Electric & 15.0 & $1-78$ & $4-78$ \\
\hline CU-4 Venture & Geysers, CA & Electric & 18.0 & $1-78$ & $4-78$ \\
\hline Agriculture Group Ind. & Calistoga, CA & Hydroponics & 2.0 & $11-77$ & $2-78$ \\
\hline Earth Energy & Geysers, CA & Electric & 15.0 & $3-78$ & $6-78$ \\
\hline California Energy, Inc. & Geysers, CA & Electric & 15.0 & $10-77$ & $1-78$ \\
\hline California Geothermal, Inc. & Geysers, CA & Electric & 15.0 & $1-78$ & $4-78$ \\
\hline $\mathrm{CU}-3$ & Geysers, CA & Electric & 12.0 & $12-77$ & $3-78$ \\
\hline $\mathrm{CU}-2$ & $\mathrm{CA} / \mathrm{UT}$ & Power Plant & 12.0 & $6-78$ & $9-78$ \\
\hline North State Growers & Susanville, CA & Non-electric & 8.0 & $12-77$ & $3-78$ \\
\hline Technology International & $\begin{array}{l}\text { Susanville Correc- } \\
\text { tional Facility }\end{array}$ & Space Heating & 0.8 & $1-78$ & $4-78$ \\
\hline Deuterium, Inc. & Geysers, CA & $\mathrm{H}_{2} \mathrm{~S}$ Scrubber & 9.0 & $2-78$ & $5-78$ \\
\hline Geothermal Kinetics, Inc. & Powers Ranch, Az & Electric & 12.0 & $12-77$ & $3-78$ \\
\hline GEDCO/Thermal Power & Hawaii & Electric & 25.0 & $6-78$ & $9-78$ \\
\hline NW Ground Covers & Klamath Falls, OR & Greenhouse & 0.4 & $2-78$ & $5-78$ \\
\hline GeoCal & Honey Lake, CA & Hydroponics & 2.5 & $11-77$ & $2-78$ \\
\hline
\end{tabular}




\begin{tabular}{|c|c|c|c|c|c|}
\hline Geothermal Kinetics, Inc. & Boggs Mountain, CA & Electric & 8.0 & $2-78$ & $5-78$ \\
\hline RLK and Company & Timberline Lodge, OR & Space Heating & 10.0 & $6-78$ & $10-78$ \\
\hline Republic Geothermal & Westmorland, CA & Electric & 22.0 & $3-78$ & $6-78$ \\
\hline Argosy & Perrine Ranch, $\mathrm{CA}$ & Exploration & 5.0 & $6-78$ & $9-78$ \\
\hline Republic Geothermal. & East Mesa, CA & Power Plant & 25.0 & $1-78$ & $4-78$ \\
\hline Geothermal Kinetics & ERDA Appl. \#5, CO & Electric & 5.0 & $12-77$ & $3-78$ \\
\hline Geothermal Kinetics & ERDA Appl. \#6, MT & Electric & 10.0 & $1-78$ & $4-78$ \\
\hline City of Susanville & Susanville, CA & Elec/Non-Elec. & .18 .0 & $12-77$ & $3-78$ \\
\hline Geothermal Kinetics & ERDA Appl. \#9, CA & Electric & 7.0 & $4-78$ & $7-78$ \\
\hline Geothermal Kinetics & ERDA Appl. \#10, ID & Electric & 10.0 & $4-78$ & $7-78$ \\
\hline Technology International & Susanville, CA & Space Heating & 2.0 & $?-78$ & $?-78$ \\
\hline Technology International & Hot Lake Resort, OR & Space Heating & 1.0 & $?-78$ & $?-78$ \\
\hline Technology International & LeGrande, OR & Space Heating & 6.0 & $?-78$ & $?-78$ \\
\hline Technology International & Boise, ID & Space Heating & 10.0 & $?-78$ & $?-78$ \\
\hline Technology International & Vale, OR & Space Heating & 10.0 & $?-78$ & $?-78$ \\
\hline Whitewater Geothermal & ID & $\begin{array}{l}\text { Space Heat/ } \\
\text { Greenhouse }\end{array}$ & 6.0 & $7-78$ & $10-78$ \\
\hline Geothermal Fisheries, Inc. & ID & Aquaculture & 1.4 & $10-77$ & $1-78$ \\
\hline Garden Valley Geothermal & Garden Valley, ID & Space Heating & 0.5 & $4-78$ & $7-78$ \\
\hline
\end{tabular}


P.S. Ogden Power Company

American Drilling and Grouting New Mexico

III. POTENTIAL APPLICATIONS

Geothermal Resources

Geothermal Kinetics

Geothermal Kinetics

Geothermal Kinetics

Diablo Exploration

Aminoil

Magma

Republic Geothermal

Coastal States oil

Renewable Energy Systems

Morningside Heights

Sonadri

\section{Lakeview, OR}

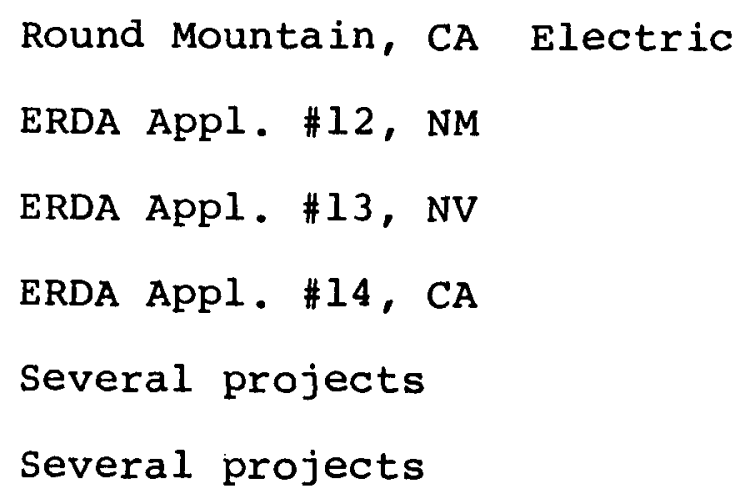

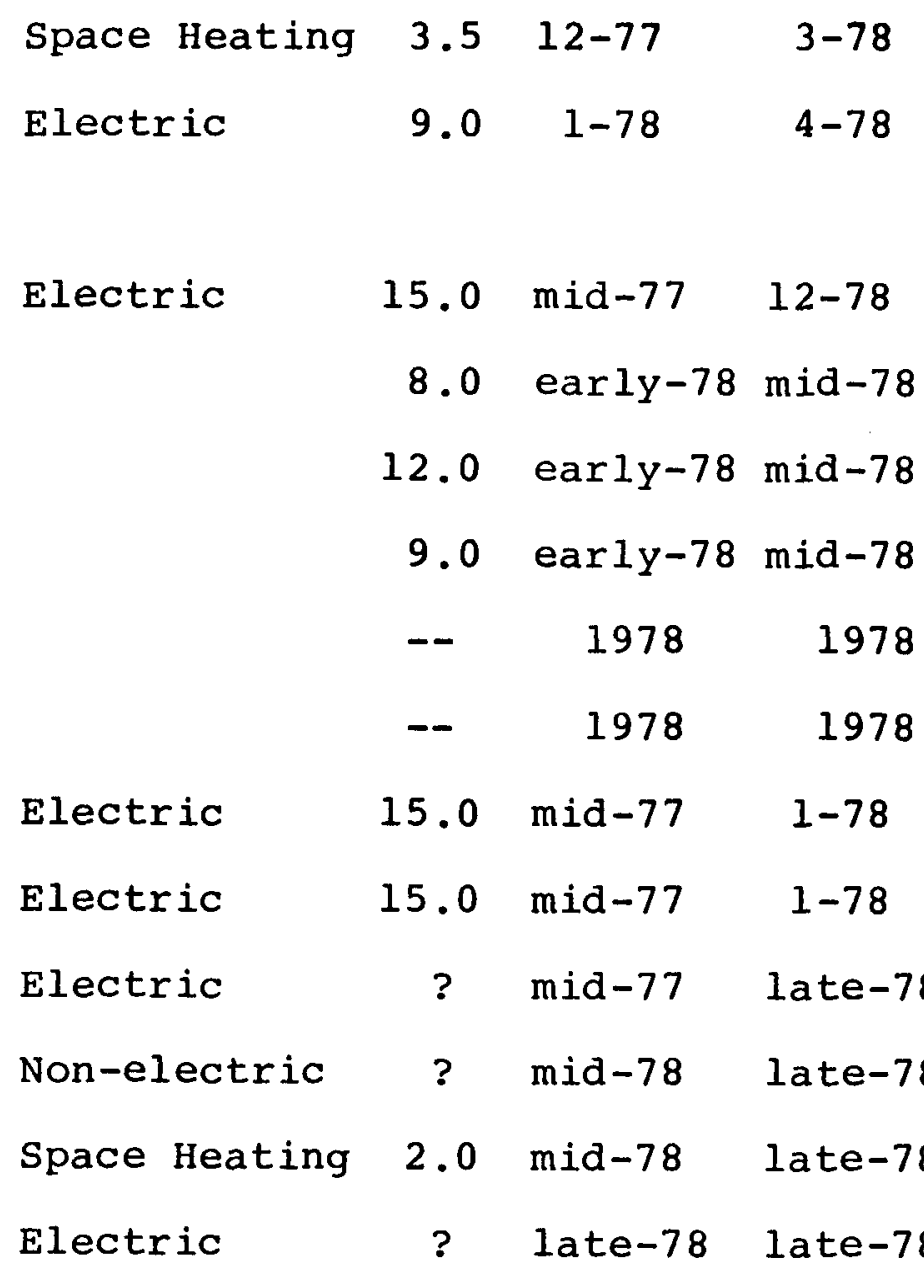

Source: San Francisco Operations office, DOE, 1977. 


\section{Table 13}

Applications Submitted for Loan Guaranties

\begin{tabular}{|c|c|c|c|c|c|c|c|c|c|c|}
\hline NUMBER & $\begin{array}{l}\text { DATE } \\
\text { RECEIVED } \\
\end{array}$ & PROJECT & LOCATION & TYPE & $\begin{array}{l}\text { TOTAL } \\
\text { COST }\end{array}$ & $\begin{array}{l}\text { LOAN } \\
\text { AMOUNT }\end{array}$ & $\begin{array}{l}\text { INTEREST } \\
\text { RATE } \\
\end{array}$ & $\begin{array}{r}\text { DAT } \\
\text { DATE }\end{array}$ & $\begin{array}{l}\text { DATE TO HQ } \\
\text { DATE APPROVED } \\
\end{array}$ & $\begin{array}{c}\text { APPLICATION } \\
\$\end{array}$ \\
\hline 1 & $10-6-76$ & $\begin{array}{l}\text { Dry Creek Exploration } \\
\text { (GRI) w/Chevron Oil }\end{array}$ & Geysers & Expl-53MW & 13.499 & 7.500 & $1208 P+1 / 28$ & $\begin{array}{l}\text { Bank of } \\
\text { America }\end{array}$ & & $\$ 7.500$ \\
\hline 2 & $10-26-76$ & GeoCal (GeoProducts) & $\begin{array}{l}\text { Honey } \\
\text { Lake }\end{array}$ & Expl-55MW & 3.654 & 2.269 & $1258 \mathrm{P}$ & $\begin{array}{l}\text { Bank of } \\
\text { Montreal }\end{array}$ & & 9.769 \\
\hline 3 & $10-26-76$ & $\begin{array}{l}\text { R-1975 Geothermal } \\
\text { Energy Drilling } \\
\text { Program (RGI) }\end{array}$ & East Mesa & Expl-36MW & 12.045 & 9.030 & $1208 p+1 / 28$ & $\begin{array}{l}\text { Bank of } \\
\text { America }\end{array}$ & $\frac{1 / 21 / 77}{5 / 6777}$ & 18.799 \\
\hline 4 & $2-28-77$ & $\begin{array}{l}\text { Cu I Venture } \\
\text { (McCulloch and } \\
\text { Geothermal Kinetics) }\end{array}$ & Brawley & Expl-55MW & 2.459 & 1.750 & $1208 \mathrm{P}$ & $\begin{array}{l}\text { Bank of } \\
\text { Montreal }\end{array}$ & $\begin{array}{l}8 / 6 / 77 \\
9 / 30 / 77 \\
(1 / 13 / 78)\end{array}$ & 20.549 \\
\hline 5 & $3-2-77$ & $\begin{array}{l}\text { So. Cal. Public Energy } \\
\text { Corporation (Burbank) }\end{array}$ & 24 sites & $\begin{array}{l}\text { Expl-50MW } \\
\text { Geo or } 200 \mathrm{Ml} \\
\text { Hybrid }\end{array}$ & 164.188 & 25.000 & $\begin{array}{l}61 / 28 \text { to } \\
1980 \\
781981-198\end{array}$ & $\begin{array}{l}\text { Dean Witter, } \\
\text { Trustee } \\
35\end{array}$ & & 45.549 \\
\hline 6 & $3-4-77$ & $\begin{array}{l}\text { Geothermal Food } \\
\text { Processors }\end{array}$ & $\begin{array}{l}\text { Brady Hot } \\
\text { Springs }\end{array}$ & $\begin{array}{l}\text { Food Dehy-- } \\
\text { dration } \\
\text { Plant }\end{array}$ & 3.815 & 2.864 & $P+28$ & $\begin{array}{l}\text { Nevada } \\
\text { Nat' } 1 \text { Bank }\end{array}$ & $\frac{8 / 6 / 77}{9 / 30 / 77}$ & 48.128 \\
\hline 7 & $3-8-77$ & Diablo Exploration & New Mex. & Expl-50MW & 29.000 & 21.800 & 8.58 & $\begin{array}{l}\text { Kidder } \\
\text { Peabody. } \\
\text { Trustee }\end{array}$ & & 70.212 \\
\hline 8 & $9-14-77$ & RFL-NCPA & Geysers & $\begin{array}{l}\text { Expl-66MW } \\
\text { Field Dev. }\end{array}$ & 19.322 & 14.489 & 8.758 & Berg $\mathrm{Co}$. & & 84.702 \\
\hline 9 & $10-29-77$ & $\begin{array}{l}\text { RGI / MAPCO } \\
\text { Westmor land }\end{array}$ & $\begin{array}{l}\text { Westmor- } \\
\text { land }\end{array}$ & $\begin{array}{l}\text { Expl-55MW } \\
\text { Field Dev. }\end{array}$ & 28.981 & 21.0 & $8.858(?)$ & $\begin{array}{l}\text { Bank of } \\
\text { America }\end{array}$ & & 105.702 \\
\hline
\end{tabular}


eleven production wells and four reinjection wells at East Mesa in the Imperial Valley. RGI plans to develop the field and construct a $45 \mathrm{MW}$ power plant on the site. The financing of the power plant will potentially be from another loan guaranty.

The second loan guaranty was granted to Geothermal Food Processors, Inc. (GFP), of Turlock, California. The project is for the design and construction of a vegetable dehydration plant at Brady Hot Springs, Nevada. Ten wells were previously drilled by Magma Power Company; four of these were considered useable for the project. According to GFP, utilizing geothermal fluids is replacing natural gas 100 percent, normally used for this type of venture. GFP expects to begin operation on september 1, 1978 .

The third guaranty granted was for a joint venture between Geothermal Kinetics, Inc., of Phoenix, Arizona, and McCulloch Geothermal Corporation of Los Angeles, California (McCulloch oil) called the CUI venture. The original application was for exploratory projects on three separate sites: Beryl and Lund in Utah, and South Brawley in the Imperial Valley, California. The Beryl and Lund projects were for completion of exploration work, drilling temperature gradient holes, and a test well at each site. The Brawley project was for drilling and testing of two wells. The loan guaranty granted was for the Brawley project only. 
The Beryl and Lund sites were not approved, basically because there was a disagreement over the temperature of the resource. The USGS projected temperatures were not in agreement with those of the applicants. In summary, ERDA was not satisfied that the risk involved was low enough to warrant the loan guaranties.

This particular application has raised several issues and is of interest when evaluating the GLGP.

1. Multiple site applications and whether or not DOE will accept these; and do the projects have to be related in order to incorporate them into one application.

2) What collateral is acceptable other than that directly associated with the project and how is the value of that collateral to be determined.

3. Differences of opinion between USGS and other consultants.

4. Most important of all, whether or not the GLGP is going to be used for exploratory projects. The GLGP is supposed to be used for exactly this purpose. If little or no risk is involved, then what purpose does the GLGP serve? Apparently the government places a probability on the risk and if it does not fall within their criterion, it is rejected. Neither the law nor the regulations has stated that the approval of a project will be judged on the projected risk associated with it. Reasonable assurance of repayment is 
a criteria, though the GLGP is supposed to assume risk, not dismiss it. How much risk should the GLGP assume?

5. CUI also raised the issue of who has the authority to "sign-off" on an application. The loan guaranty was originally approved on september 30,1977 , the last day of ERDA, by the Acting Administrator. There was an ensuing debate over this and was given final approval on January 13 , 1978 by the DOE Deputy Secretary acting for the secretary. This type of situation has done little to promote the program and the credibility of those involved and the government. (A DOE document assigning the duty to the Director of Procurement and Contracts Management had been issued on october 3 , 1977$.

The Dry Creek/Chevron application (Dry Creek is a subsidiary of Geothermal Resources International) is still not complete. Dry Creek and Chevron have an agreement where Chevron would be the operator. Dry Creek is currently amending its application to deepen an existing well chevron drilled. Delay was due to the difficulty Dry creek had in obtaining proprietary data from Chevron. Chevron's concern was the protection of these proprietary data. This seems to have been resolved now and Dry creek is hopeful for completion of the application. 
Geocal, a subsidiary of Geoproducts, submitted an application for development of a power plant at Honey Lake, California. There was a difference of opinion between the applicant and USGS concerning the temperature. The application is being held in obeyance but has been "informally rejected". Geocal expects to submit an application for a hydroponics facility on the same property. Geocal also submitted a proposal for the nonelectric Program opportunity Notice (PON) (cost-shared program) which it did not receive. It was hoped that the amount of the PON would be used for partial financing of the hydroponics project and be deducted from the amount of the loan guaranty. There are conflicting opinions within SAN on the legality of such a procedure, although the regulations, $\$ 790.21(19)$ and $\$ 790.43(a)$, clearly allow it. The Southern California Public Energy Corporation (City of Burbank, California) submitted an application for exploration and construction of an electric generating plant. A site has not yet been chosen and they would prefer to use a partially developed lease which would eliminate any of the leases they presently have access to. One possibility was a 500-750 MW hybrid power plant using geothermal (20-40 percent) and coal (60-80 percent). Burbank's demand is $250 \mathrm{MW}$ and is seeking additional users to enter into an agreement; Pasadena, California is a possibility. 
Diablo Exploration of Oakland, California submitted an application for exploration and eventual construction of a power plant in New Mexico. Diablo has an agreement with Public Service of New Mexico to sell electricity but is looking for an operator to conduct drilling and supply needed capital.

The Northern California Power Agency (NCPA), a group of 11 municipalities, and Resources Fund Limited (RFL), have an application for a arilling program possibly leading to construction of two power plants at the Geysers. There is a legal dispute concerning the property. NCPA is working on another application for construction of power plants on federal leases held by Shell oil Company. Shell and NCPA have entered into an agreement whereby Shell will supply steam. NCPA assumed the Technical Amendments would be signed into law and must also negotiate a contract to transmit the electricity with Pacific Gas and Electric Company (PG\&E) of San Francisco, California.

Republic Geothermal (RGI) and Mapco, Inc. of Tulsa, Oklahoma, have submitted an application for exploration and potential construction of a power plant at Westmoreland in the Imperial Valley, California. This is the second application for RGI. The application is undergoing evaluation by the various consultants and was sent to Headquarters (HQ) in November, 1977 for preliminary review. 
Application Process and Review

A set of application guidelines may be obtained from the GLGP office at the DOE San Francisco Operations office (SAN). There have been three publishings of these guidelines; June, September, and December, 1976, with changes in each. An applicant or any interested party should obtain the most recent edition of the guidelines.

The guidelines include a general description of the program and the procedures for applying, a copy of P.L. 93410, Rules and Regulations (10 CFR 790), an application form (Appendix $\mathrm{K}$ ), and a description of the information required by the borrower and lender.

The SAN-GLGP staff assists the applicants in preparation of the application and makes a recommendation to the Manager of SAN for approval or nonapproval of the project. The GLGP staff is divided into five specialized areas: management, finance, marketing, geology, and legal.

The applicant supplies data including: a) environmental reports, b) geological, geophysical, and geochemical data, well data, c) utilization process, d) financial information about the firm, e) project economics, f) management capabilities of the firm, g) a milestone plan describing the project goals, h) marketability of the resource, and i) legal data concerning the projects assets, leases, pending litigation, patents, permits, and the structure of the organization. 
The lender supplies financial and management information, and legal documents: a) a description of the management experience of staff associated with the project, b) current audited financial statements, c) loan agreement, and d) lender's assessment of borrower's loan application. These requirements are presented in detail in the application guidelines and regulations. Appendix L represents a draft of a Loan Guaranty Agreement.

Figure 3 represents the stages an application follows. The United States Geological Survey (U.S.G.S.) conducts an assessment of the resource and supervises field work if a guaranty is granted. The USGS evaluates the level of risk associated with a particular area. This evaluation is based on temperature at depth, permeability, and fluid chemistry when a well has been drilled. The USGS must decide whether or not data submitted by the applicant are complete or not for the evaluation.

The applications are sent to other consultants for technical, economic, and environmental evaluations:

- Idaho National Engineering Laboratory (INEL), Idaho Falls, Idaho - technical and economic evaluation.

- Oak Ridge National Laboratory, Oak Ridge, Tennessee environmental evaluation. 
Fiqure 3. Flow Chart of Application Processina

22. Recommend

Pre

application

meeting

-

2. Resource technical

data to SA

for USGS"

4. Consul

tants assign ment meeting

i - - I Application Hlq. staff J $-\ldots-\ldots$

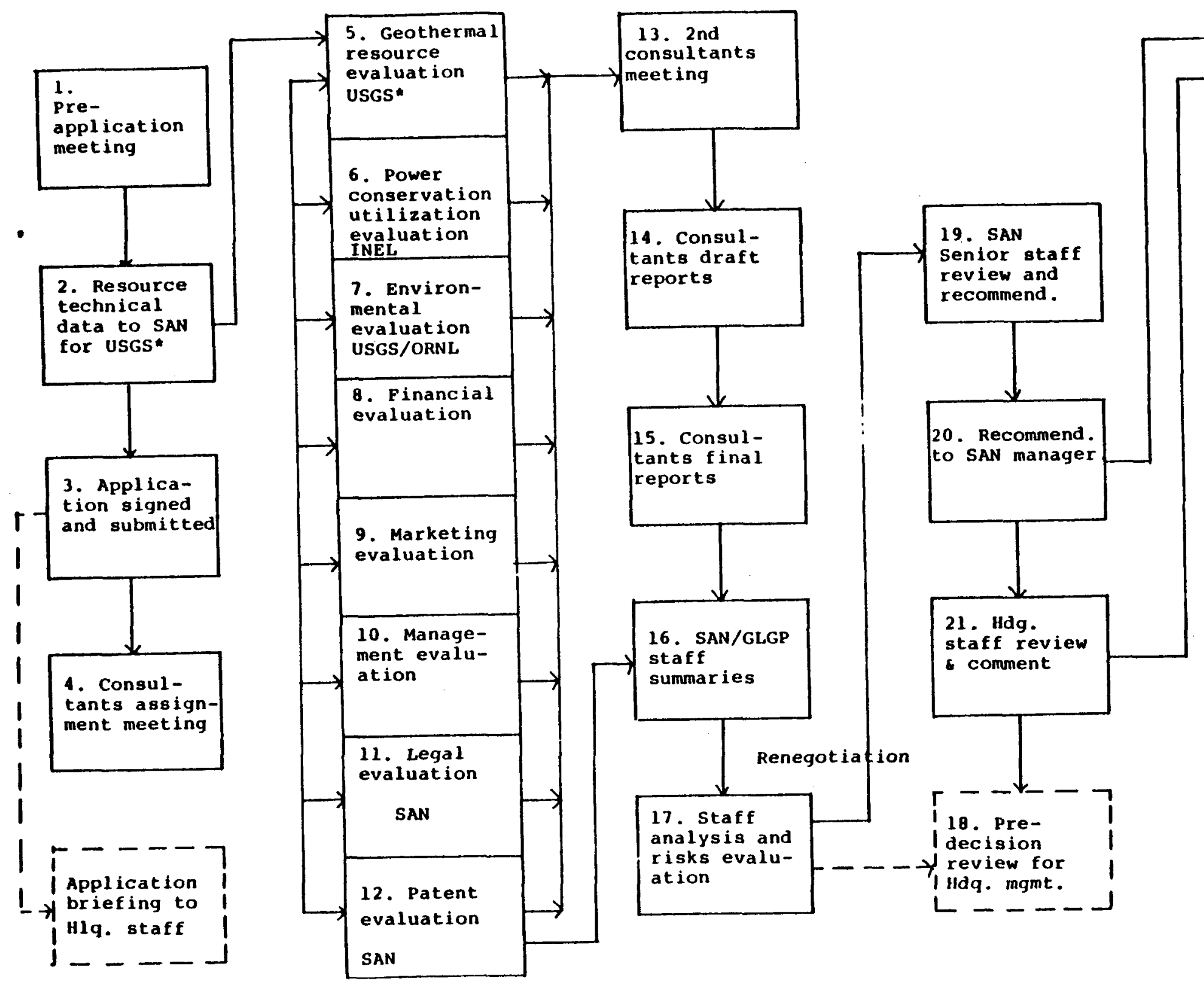

to

Administrator eports

15. Consul tants fina reports

17. Staff

risks evalu-$$
\text { ation }
$$

I lidq. mgmt.

26. SAN Okays

c monitors

25. SAN cloge agreement
Source: San Francisco Operations office, 1977.

- Long Lead-Time Item 
- Stanford Research Institute, Wilsey \& Ham, Arthur Young, or National Economic Research Assoc. (NERA) economic evaluation.

The consultants employed for the economic evaluation vary and additional firms are under consideration.

A loan application contains the following sections:

1. Recommendation Package

2. Staff Analysis

3. Loan Guaranty Agreement

4. Statement of Negative Determination

5. Administrator's statement of Findings

6. Memo: Administrator to Manager

7. Application

8. General Overview of Project

9. Staff Summaries

legal environmental

geo resource/utilization financial marketing management patents USGS report - resource assessment ORNL or USGS report - environment INEL (EG\&E) report - technical and economic economic report supporting legal information 
After the consultants and GLGP staff submit their reports and evaluation of the project, the package undergoes a Senior Review by the SAN staff. Finance, Procurement, Environment, and General Counsel review the application, make comments, recommendations, and point out problems or the need for additional material.

After the "in-house review" is conducted, a recommendation is sent to the SAN Manager. The program package with the recommendation of the SAN Manager, is sent to Headquarters $(\mathrm{HQ})$ in Washington. It is still not clear at what stage the package should be forwarded to HQ. SAN recently sent the fourth application to HQ in advance of the completion of the review, hoping to speed up the time spent in reaching a final decision.

Under ERDA, the Division of Geothermal Energy (DGE) managed the program. No application has undergone any review since the transition to DOE. The management of the program was changed to Resource Applications. They have not determined how the program will be handled and are still working up a workload schedule.

In DGE, the position of the Chief of the Loan Guaranty Branch was filled for the first application only (RGI). For the review of the second and third applications (CUI and GFP), the position was temporarily filled by a staff member from Solar, Geothermal, and Advanced Energy Systems. 
A total of four applications were sent to HQ. The first three (RGI, CUI, and GFP) were sent from SAN with recommendations for approval. The fourth application was sent in November, 1977 before any recommendation was made or consultant's reports completed. Any questions concerning the application could be taken care of before SAN sent a recommendation.

The RGI, GFP, and CUI applications were sent to HQ and then distributed by one central staff person to HQ personnel. The fourth application was sent directly to persons reviewing the project. Basically, the copies were given to the following groups :

1. Office of Energy Financing, Office of the Controller (OC)

2. General Counsel (GC)

3. Environment and Safety (AES)

4. Division of Geothermal Energy (DGE) of Solar, Geothermal, and Advanced Energy Systems (ASGA).

Within DGE, several staff members from various groups reviewed the applications, including: 1) Resource Utilization, 2) Resource Assessment, 3) Environmental, 4) Utilization Technology. Other DGE staff members were also asked to review the applications. General Counsel does a general legal evaluation including contractual agreements, titles, ownership 
of assets and collateral, and National Environmental Policy Act (NEPA) of 1969 issues. The Office of Energy Financing. of Controller's office (OC) determines the risk associated with the proposed project, whether the equity is sufficient and the applicant has incurred risk also. OC also determines whether there exists "reasonable assurance" that the loan can be repaid. If project assets or cash flows are insufficient for repayment, OC evaluates any additional collateral. Other areas examined by the various divisions determine whether or not there exist: a) environmentally acceptable means of exploration and development, an Environmental Impact Assessment (EIA) is prepared for this purpose, b) whether the resource is sufficient to support the proposed commercialization project, and c) technical feasibility of the proposed project.

These are some of the major areas examined but this list is not all inclusive of the types of questions raised during the reviewing of the applications. An application is not always in its completed form. Consultant reports and environmental impact reports may be delayed. These delays are not insignificant and add time to the review process. The review was originally scheduled to take from 90 to 120 days (3-4 months). Applicants have expressed desires for this to be shortened, preferably to 3 months. 
Table 14 represents the amount of time an application has taken from start to finish to process.

Table 14

Application Processing

First contact

to submission

of application

SAiv HQ Total

East Mesa

(Republic Geothermal)

6

9

GFP

CUI

Totals

Average

Average time spent in government - 8.66 months. Source: SAN, 1977.

Under ERDA, the Assistant Administrator for Solar, Geothermal, and Advanced Energy Systems (ASGA), the Assistant Administrator for Environment and Safety, Controller, and General Counsel (GC) had responsibility to agree to disagree with SAN's recommendation. The Administrator had the authority to overrule the above mentioned decisions and had final approval or disapproval authority for geothermal loan guaranties. All four parties in the past did not concur with the recommendation for approval by SAN on the three applications. 
Under DOE it is not yet clear who will have this authority. The program management is now with Resource Applications and the Director of Procurement and Contracts Management has authority for the final decision.

Prior to the ERDA-DOE transition, papers were being generated on how to more effectively process and review the applications and draft a policy and procedure for this purpose. The first loan guaranty was approved in May, 1977. And since that time, almost one year ago, it has not yet been resolved. The ERDA-DOE transition can account for some of the delay but primarily it is politics, power, and personalities involved. The role and responsibilities of the Controller, Assistant Secretary Environment, Assistant Secretary Energy Technology, Assistant Secretary Resource Applications, General Counsel and Director of Procurement and Contracts Management are not at all clear. Until this is resolved, the reviewing of any loan guaranty applications will be an extremely time consuming process.

In summary, several reasons exist for delays in the processing of the applications:

1. There exists no formal procedure for reviewing the applications,

2. USGS does not have the time, considering their workload, to meet the prescribed 3-week deadline (dependent on leasing schedule), 
3. Some personnel at $\mathrm{HQ}$ and USGS do not give the loan guaranty program reviews equal consideration along with their other responsibilities.

4. application quality varies extensively and often additional information is required, and

5. it has not been determined who has authority for the decision to approve or disapprove a loan guaranty.

Figure 4 illustrates the concurrence chain under ERDA and Figure 5 is the situation under DOE at the time this paper was written (March, 1978).

In addition, many policy issues regarding the GLGP have not yet been resolved.

1. What qualifies as the 25 percent equity share; is the market value of historic cost of any assets to be used in determining this?

2. Resolving differences of opinion between SAN and $\mathrm{HQ}$.

3. How to handle multiple-site applications.

4. Are lease acquisition and exploration (wildcatting) going to be allowed for loan guaranties?

5. Should greater responsibility be given to SAN? 


\section{Figure 4. Geothermal Loan Guaranty Program Flow Diagram Energy Research and Development Administration (ERDA), June, 1976-September, 1977}

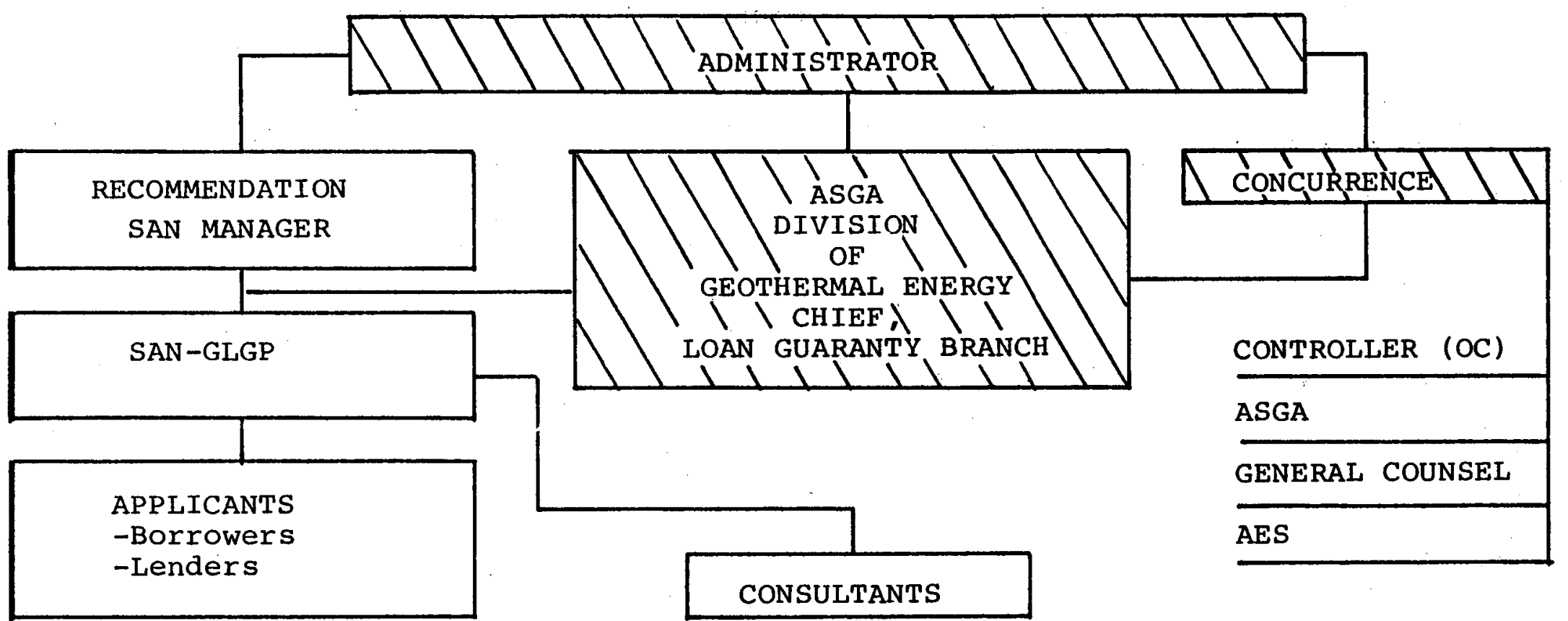

SAN -San Francisco Operations OFfice

ASGA - Assistant Administrator for Solar, Geothermal, and Advanced Energy Systems AES -Assistant Administrator for Environment and Safety

Lined areas represent Headquarters, Washington, D.C. 
Figure 5. Geothermal Loan Guaranty Program Flow Diagram Department of Energy (DOE), as of February, 1978.

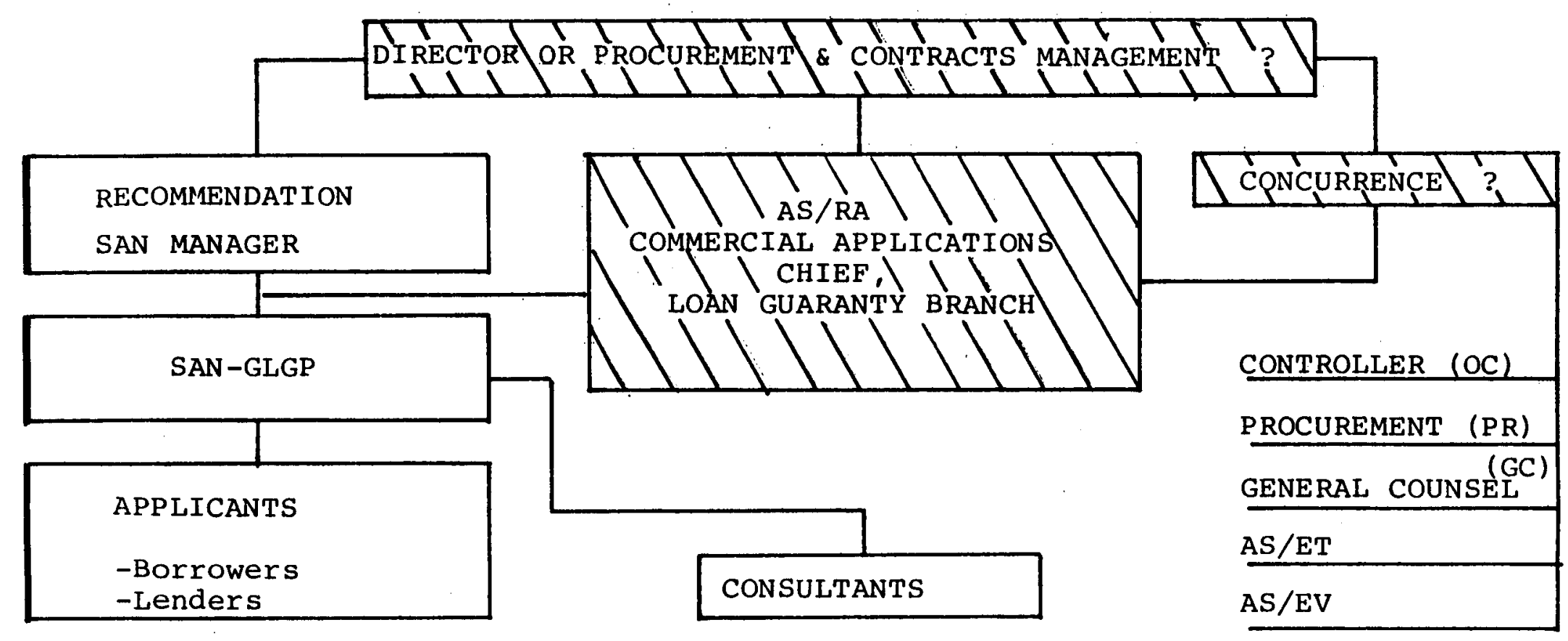

SAN -San Fráncisco Operations office

AS/RA-Assistant Secretary Resource Applications

AS/ET-Assistant Secretary Energy Technology

AS/EV-Assistant Secretary Environment

Lined areas represent Headquarters, Washington, D.C. 


\section{EXTERNALITIES AFFECTING THE GEOTHERMAL \\ LOAN GUARANTY PROGRAM}

The Geothermal Loan Guaranty Program is directed at lowering the financial barriers to geothermal development. There exist several factors that have not allowed for capital flow into geothermal resource development. These factors, with time and experience, would probably be eliminated and definitely less constraining. Reservoir uncertainties, unproved technology, economic performance, and historically conservative attitudes of utilities and bankers have led to a high risk situation and a lack of confidence in the utilization of geothermal resources.

The Geothermal Loan Guaranty Program cannot be of service if the barriers to submitting an application for a loan guaranty are prohibitive. These problems have been recognized by the government and industry, but it is crucial to acknowledge the environment in which the loan guaranty is expected to function. Even with current or near current technologies, geothermal resources cannot be duly exploited without the elimination and streamlining of these "externalities." 
If a firm cannot acquire leases and drilling permits, no amount of financial assistancewill be of significance. The affects of these external factors on the Geothermal Loan Guaranty Program are outlined in this chapter.

\section{General Overview}

The author has determined the following areas which have had an impact on the performance of Geothermal Loan Guaranty Program.

1. Government policy, attitude, political environment, delay in passing legislation.

2. Tax treatment: intangible drilling cost write-offs and depletion.

3. Legal issues: definition and ownership of the resource.

4. ERDA-DOE transition: organizational change impact on the GLGP.

5. Government supports affecting the GIGP; Demonstration and Reservoir Case History Programs.

6. Permit acquisition: time and expense.

7. Lease acquisition: acreage limitation, delays, bonus bidding, leasehold size, reclassification.

8. Environmental reporting requirements and regulations: federal, state, and local.

9. State and local development of legal and regulatory issues.

10. Steam pricing: based on costs of alternative fuel prices. 
11. Contractual agreements to sell electricity to utilities or to transmit electricity through utility systems.

12. Utility rate structure and regulatory constraints.

13. Cost factors.

14. Innovation, education, and general public awareness of geothermal resources.

15. Industry misconceptions of the GLGP: need for information dissemination.

Many of these items cited are of a more general nature in that they affect the geothermal industry whether or not there exists a loan guaranty program; however, some are specifically detrimental to the GLGP. The relationship between these factors and the GLGP illustrates their potential impact on the GLGP.

\section{The ERDA-DOE Transition}

The ERDA-DOE transition and reorganization (P.L. 95-91, Department of Energy Organization Act) of $10 / 1 / 77$, has not yet been completed. Divisions within DOE are unsure as to which has authority and what functions it is expected to perform for the Geothermal Loan Guaranty Program.

Under ERDA, the Division of Geothermal Energy of the Solar, Geothermal, and Advanced Energy Systems Division, was responsible at Headquarters (HQ), Washington, D.C., for administering the review of applications from the San Francisco Operations office. The Administrator of ERDA had 
final authority to sign for approval or disapproval of a loan guaranty. A DOE Interim Management Directive (IMD) dated Sept. 13, 1977, "DOE Organization" authorized the Director of Procurement and Contracts Management (PR) as the one who..."negotiates and administers all contracts and grants, cooperative agreements, and loan guarantees at headquarters and oversees those performed in the field." Another IMD dated October 3, 1977, "Continuity of Operations, Authority Delegations, and order of Secretarial Succession in the Department of Energy," contained the following authority delegation to the Director of Procurement and Contracts Management:

"Enter into, approve, and take such other action as may be necessary and appropriate with respect to any contractual arrangement, interagency agreement, grant, loan guarantee, or other similar action committing the Department of Energy (DOE) to applicable laws, policies, regulations, and procedures. Such action shall include determinations and decisions except those determinations and decisions required by law or regulation to be made by other authority;..." Signed James R. Schlessinger, Secretary of Energy, effective October 1, 1977 (IMD No. 0204, U.S. DOE).

These delegations clearly stated that the Director of Procurement and Contracts Management has authority for the GLP. The DOE Fact Book of Organization and Functions published on September 13, 1977 states the Assistant Secretary for Resource Applications has "program responsibility." An ERDA division, Commercial Applications, now under DOE's 
Resource Applications, employs a staff position of Chief, Geothermal Loan Guaranty Program, ariginally under DGE during ERDA.

The Secretarial delegation of authority to the controller does not mention loan guaranty programs, however, the DDE Fact Book includes "administer financing studies for loan guarantees" as a function of this office.

It has not, as of the writing of this report, been determined what responsibilities for the Geothermal Loan Guaranty Program will be delegated to the following three divisions: Controller, Procurement, and Resource Applications (Commercial Applications). Each of these offices has generated proposals on how to deal with this. Resource Applications would like the Assistant secretary (AS/RA) to be delegated the final authority. The loan guaranty approved on January 13, 1978, was signed by the Deputy Secretary of DOE and not by the Director of Procurement and Contracts Management; one wonders how effectively a program can function under such confusion.

In addition to the problem of defining roles and functions, some of the key personnel have changed even since October 1, 1977, DOE's birthday. Many of the Assistant Secretarial positions, including Resource Applications, were not confirmed by Congress until early 1978, several 
months later. Changing staff and offices has afflicted the GLGP, not only in the ERDA-DOE changeover, but also before DOE. The person having authority for approving has changed three times, although the Acting Administrator of ERDA signed for all three loan guaranties and the Deputy Secretary of DOE signed again for the CUI venture. The Manager of the San Francisco Operations office has changed hands at least three times since June 1976, startup for the GLGP. The Director of DGE changed twice and the position of Chief, Geothermal Loan Guaranty Program, was vacated during the review process of two of the three applications and filled temporarily by a member of the staff of Solar, Geothermal, and Advanced Energy Systems. That position, now in Commercial Applications was returned to the original Chief of the Loan Guaranty Program.

The DOE organization has shifted program responsibility and therefore created confusion and lack of management for the program. The program has suffered in terms of time, and credibility or confidence by the applicants.

SAN has had to deal with new personnel, to educate and negotiate with each change, to familiarize them with the program. More destructive has been the lack of continuity and structure. With whom does the responsibility lie, to whom does the application get sent, with whom should SAN negotiate, who has to be satisfied at Headquarters? These questions have not been satisfactorily answered. 


\section{Leasing}

Leasing activity has been hindered by government regulations and slow processing of lease applications.

Barriers to leasing include acreage limitations of 20,480 acre maximum per state, reclassification of overlapping noncompetitive lease applications, and regulations that allow for exploration without permits on unleased land. If noncompetitive lease applications overlap by 50 percent or more, the land is reclassified as a KGRA and thus cancels the applications and competitive bids must be made.

There exists means to circumvent some of these: land holding companies, (increase to 51,200 acres is pending), and irregular shaped acreage in lease applications. An operator takes a risk if he should do exploratory work on unleased property and as a result of his efforts the acreage is reclassified as a KGRA. It is now open to competitive bonus bidding, thereby the operator loses the eccnomic advantage and increases competition for the property.

In addition, due to reclassification regulations, Gerald Kitchen of Amax, Inc., points out:

"...If an operator intends to include federal acreage in his land package, the reclassification problem requires that he puts the brakes on his exploration project--even on adjacent private lands-until the leases are issued." (Geothermal Resources Council Short Course No. 4, 1976). 
In order to conduct exploratory work on a federal lease the operator must adhere to the various regulatory requirements involving permits and environmental reports. The procedures outlined here cover only the federal requirements; state and local regulations to obtain permits and submission of environmental reports must also be adhered to.

\section{Environmental Regulations}

Figure 6, Flow Chart of Critical Path in Geothermal Exploration, identifies the various agencies, and requirements for six phases of geothermal development. In order to conduct initial exploration prior to leasing, a pre-lease exploration permit must be acquired from the Bureau of Land Management (BLM). A firm files a Notice of Intent to Conduct Geothermal Resource Exploration in order to obtain the permit. The BLM must prepare an Environmental Analysis Record (EAR) and a post-lease Environmental Analysis (EA). An application for a Permit to Drill must be obtained from the USGS and a Plan of Operation is submitted for surface or well work. Much delay and expense is involved in these requirements where the BLM and/or USGS has been slow to complete these requirements, resulting in more time lost and a potential increase in costs to the operator. Equipment and labor must be scheduled to conduct the work, making the streamlining of permitting requirements vital to development. 
Figure 6. Flow Chart of Critical Path in Geothermal Exploration.

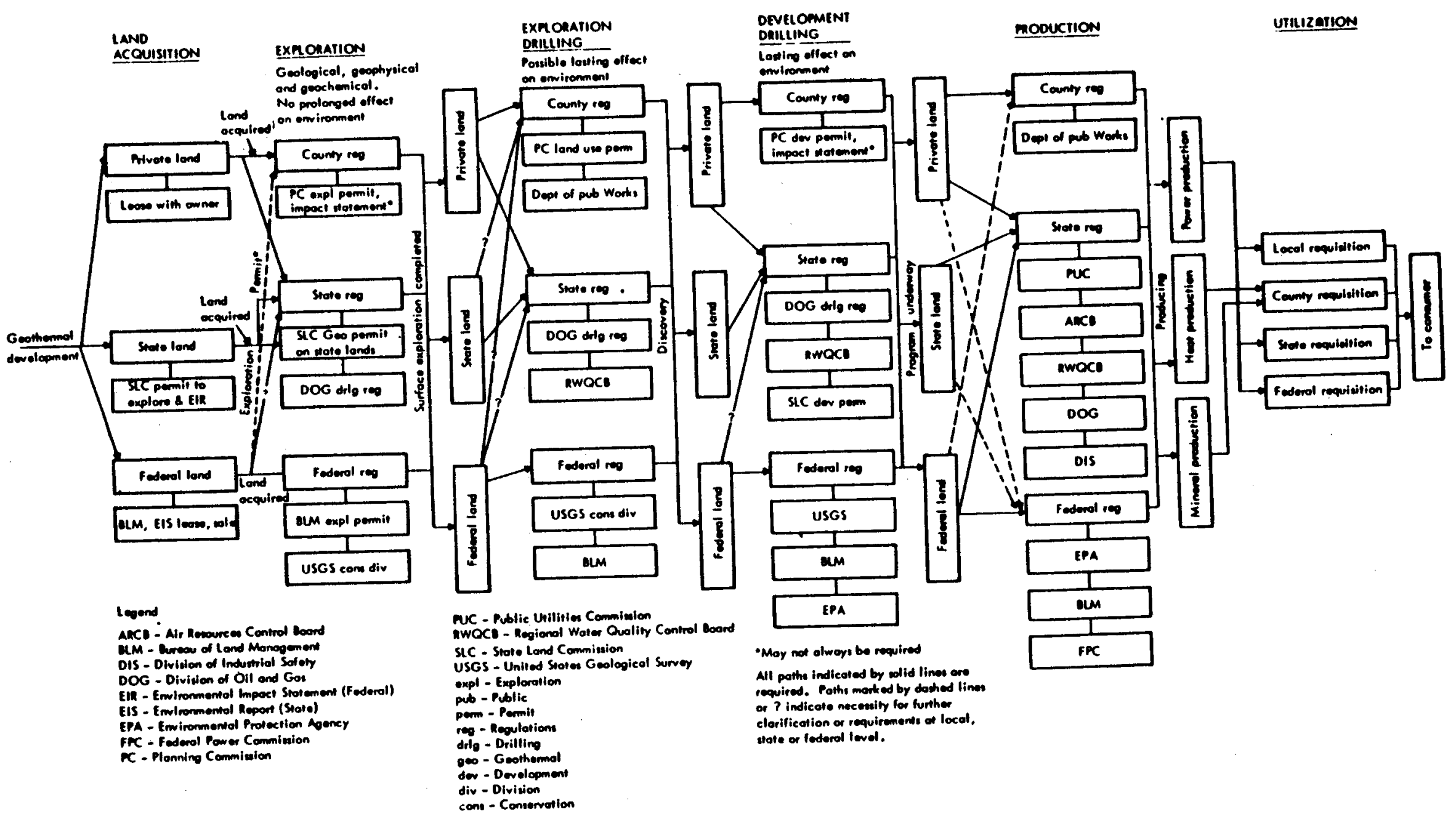

Source: Howard, J.H., editor, Present Status and Future Prospects for Nonelectrical Uses of Geothermal Resources, 1975, p. 101. 


\begin{abstract}
"The lack of both environmental data and standards slows the environmental approval process. Moreover, the approval process is further slowed by lengthy, complex and often apparently inconsistent rules, laws, and regulations at federal, state, and local levels. The overlay of jurisdiction of the responsible agencies further compounds the process, and has caused much unnecessary duplication of industrial effort in preparation of environmental statements. The uncertainty of ultimate approval and the time involved in obtaining approval have been cited by the industry as major deterrents to geothermal investment." (ERDA Vol. 2: Program Implementation).
\end{abstract}

In some geographic localities the number of permits required ranges from 40 to 70 ; a staggering amount of time and money is devoted to this. The applicants and potential applicants for a loan guaranty most often cite the environmental reporting requirements as the major problem area. Table 15, Federal Regulations Applicable to Geothermal Resource Development Projects, is a list of eight federal laws involving environmental, leasing, and various other regulations. It is hoped this list will impress the reader with the magnitude and complexity of the issue.

Demonstration Program

The Geothermal Demonstration Program is possibly affecting the GLGP by creating competition for applications. The demonstration program is possibly being used at the expense of the GLGP. 
Table 15

Federal Regulations Applicable to Geothermal Resource Development Projects

1) Geothermal Steam Act of 1970 (Public Law 91-581, 84 Stat. 1566).

2) Clean Air Act of 1970 (Public Law 91-604, 42 USC 1857 et seq.)

3) Federal Water Pollution Control Act Amendement of 1972 (Public Law 92-500, 86 Stat. 861).

4) Norse Control Act of 1972 (Public Law 92-574, 86 stat. 1234).

5) Coastal Zone Management Act of 1972 (Public Law 92-583).

6) Endangered Species Act of 1973 (Public Law 93-205, 87 Stat. 884).

7) Geothermal Energy Research, Development, and Demonstration Act of 1974 (Public Law 93-410, 88 stat. 1079).

8) Federal Nonnuclear Energy Research and Development Act of 1974 (Public Law 93-557, 88 Stat. 1878).

Source: Guidelines to the Preparation of Environmental Reports for Geothermal Development Projects, February 1977.

These two programs are aiming toward the same goals using different means; and it may be that one is preferable for developing the resource. The loan guaranty program will have longer and further reaching impact than the demonstration program in that it develops the financial communities knowledge of the resource and the capital requirements. The Demonstration Program may make possible an otherwise uneconomic project but this does not necessarily encourage 
additional power plants. If the project is uneconomic without federal subsidy, it will not be undertaken without these funds. If the project is economic without these funds but the obstacle is capital acquisition, the GLGP can be used in its place. The author doubts very much that any firm would use borrowed money when it can obtain 30 to 50 percent of the costs without having to pay them back. Unless power plants are economic, they will not be built no matter how many demonstration plants exist.

Several of the arguments in favor of the demonstration program over the GLGP for power plant construction are erroneous. The proported delay of a "decade or two," if the demonstration program was abandoned, has no substance and will not be the case.

The same holds true for the view that the GLGP "...will have little applicability as a financial vehicle for constructing power plants..." This was based on the thinking that only utility companies would be building power plants and did not need the guaranty to raise capital. It is now demonstrated that several small firms, in cooperation with the larger firms are applying for loan guaranties to construct power plants.

No loan guaranties have been granted as yet for this type of project but the prospect of this occuring is encouraging. If the government has enough faith in the 
viability of such a project to give away tens of millions of dollars, one would think the government should risk at least the same amount for a loan guaranty where there exists an opportunity for repayment.

The Geothermal Loan Guaranty Program has had to function and co-exist with these various "externalities." The impact of these factors needs to be recognized. The situation must be corrected if we expect the program to have any impact on developing geothermal resources. Much has been devoted to the more obvious and conventional barriers in the literature. The ERDA-DOE transition, low priority among DOE staff, and demonstration program are less known factors, whose impact is as great or greater in damaging the performance of the program. 
EVALUATING THE GEOTHERMAL LOAN GUARANTY PROGRAM: ATTITUDES AND PERSPECTIVES

The perspective of industry, lending institutions, and the utilities of the GLGP are vital to its success and implementation of any change in the operation or requirements. Views generally held by these groups are presented here. With each geographic location, within each company, depending on the resource and the utility, views of the GLGP differ. Some see it as a tool for exploration and others believe its only viable use will be in the construction of power plants. Others feel that exploration and wildcatting should not be a part of the program, citing its high risk and the availability of capital for exploration through other means.

Discussed here are the perspectives of the industry first, which are separated into two main groups: large integrated firms including major oil companies, and smaller independent firms. These two groups vary in their analysis of the program. 
Secondly, utility companies are discussed, whose views vary depending on their need and size. Thirdly, lending institutions, who generally are in agreement about the program. Finally, the author will evaluate the program from an outsider's vantage point having been exposed to all of the above mentioned groups.

\section{Industry Evaluation}

It is generally agreed that not much has happened in the development of geothermal energy. The industry believes that intangibles and depletion write-offs and better federal leasing practices will stimulate development of geothermal resources. Geothermal drilling funds compete with oil and gas funds, where favorable tax writeoffs exist. However, legislation is pending to allow for IDC's.

The U.S. House of Representatitives, Sub-committee on Energy Research, Development, and Demonstration held hearings and solicited comments from the industry regarding the Loan Guaranty Program. The general consensus of opinion was favorable and enthusiastic with respect to the need for the program.

The larger firms never saw it as a viable tool for themselves, they cite the following reasons for this: the 25 percent equity requirement is unappealing, political 
climate and fear of defaulting being bad public relations. The large firms are prime rate borrowers which represents cheaper capital than the Loan Guaranty Program could offer.

To the smaller firm, the Loan Guaranty Program may offer cheaper money, permits retention of full control and ownership of interests. This may also have a positive effect on the firms' rate of return. Many feel that without the GLGP they would not be able to go ahead with projects. The high leverage, long-term loans are attractive to these firms. The larger firms are becoming involved in the GLGP, through contracts to supply the resource and/or by agreeing to be the operator, while the smaller firms make the applications for a loan guaranty. This arrangement has not yet been worked out in a loan guaranty but the industry is hopeful that DOE will approve. The large firms do not care for building and operating a power plant and have little desire to become involved in the "utility business." The following remain obstacles for this type of arrangement: price of electricity, price of steam, transmitting tre electricity, utility involvement and possibly purchase. Enthusiasm in no way resolves these problems.

According to the industry representatives and lenders contacted, the guidelines are clearly written and easy to understand. No one had any difficulty with these, but found that the newest edition was an improvement over the previous ones. 
One of the problems in getting people to respond to inquiries regarding the program is that they have not thoroughly familiarized themselves with the program. only the applicants have been able to respond directly to these aspects of the program. Much of the industry is becoming familiarized with the program through the efforts of lenders in promoting the program. Many firms are not yet at a point where they feel advantage can be taken of the program.

There exists a diversion of opinion on what is the best use for loan guaranties. The law provides that all phases of development, including lease acquisition, exploration, field development, and power plant construction can qualify for a loan guaranty. Some believe its best use is for capital intensive construction and not exploration, while others feel it is most useful in exploration. Those who believe the GLGP should be used for wildcatting, usually smaller firms holding leases, are not pleased with priorities the regulations have set.

High risk and high drilling costs are associated with exploration ventures. One view is that, due to high risk and the incurred costs, no loan guaranties should be made for this purpose; it would end up subsidizing the industry because of the little possibility for repayment. The other view is that this is exactly what the program's function should be. 
The high risk and costs are exatly what is inhibiting new discoveries and without discovery, the exploitation of geothermal resource potential is impossible. Developing proven resources is less risky and will be undertaken by resource firms if there is a purchaser for the resource. Guarantying exploration activity will probably mean greater probability of default; but that this should be the purpose of the program. They feel that if the government is not willing to accept the risks, then the program will fail. Possibly a limited dollar amount should be placed on guaranties for exploration but these activities need to be guaranteed.

This divergence of opinion and philosophy surrounding the use of loan guaranties also exists between SAN and HQ. Section 201 (d) of P.L. 93-410 requires that there exists "reasonable assurance of repayment of the loan." Repayment may be from projectassets or other collateral, or funds generated from cash flows associated with the project. The "reasonable assurance of repayment" presents another variance in interpretation between SAN and HQ. SAN believes the GLGP is to assume greater risk than normally undertaken in business ventures while HQ has a more conservative interpretation of the allowable risk for granting loan guaranties.

Basically, it is agreed that the GLGP will assist the smaller firms and not the larger integrated firms who have little or no financial problems. 
Applicants agree that the government and GLGP staff have learned a lot in a short time but are not yet proficient in handling the various types of projects and financial arrangements. The GLGP is inefficient compared to inhouse financing by a firm and the cost is greater. However, the GLGP lowers the risk substantially to the borrower and this has great appeal.

Problems associated with the GLGP from the applicants' point of view are:

1. Cost of preparing an application

2. Reviewing time

3. Environmental requirements

4. 25 percent equity (for some)

5. Consultants may be incompetent and possibly delay review The need to shorten the time in reviewing an application is vital. The cost of an application, $\$ 40,000-\$ 100,000$ and more, is too high. Information and environmental reports ordinarily not needed add to the high costs. As the process is streamlined and requirements defined and understood, this cost will likely be reduced. But, even with the high cost, all agree they will use the GLGP again.

In summary, the industry generally believes that the GLGP will be used by smaller firms which have trouble raising capital. 
Utility Evaluation

The utility industry has its specific considerations when evaluating the GLGP. The utility business is a regulated industry and the rate structure and capital availability does not allow for participation in the GLGP. Utilities are not interested in using the Loan Guaranty Program as they have not committed themselves to geothermal energy. Lack of confidence in the reservoir, capital allocated for conventional fossil-fueled plants, high risk, all contribute to the policies of the utility industry. They are, however, interested in making contractual agreement for purchasing electricity with possibly purchasing the power plant after it has been proven.

Some utilities prefer to finance projects entirely with sale of revenue bonds and maintain a low debt/equity ratio. However, several municipal utilities have shown interest in the GLGP (Susanville, Burbank, and NCPA). Their interest in the GLGP arise because of the lower risk and high leverage but are not interested in making a profit, only in supplying customers with a cheaper source of power. NCPA believes it can offer a lower price when generating its own electricity.

The utility industry is also divided into two camps. Depending on demand, location, alternative energy sources and economics each utility considers the GLGP. Of those 
spoken to, none except the three municipal utilities of Burbank, Susanville, and NCPA is likely to use the program.

Lending Institutions

Commercial banks and brokerage firms are very interested in lending with the GLGP. Figure 7 is a breakdown of types of institutions and their interest in loan guaranty programs. Commercial banks do not like to engage in long-term (greater than 10 years) debt financing. Projects such as power plant construction will have to be financed with a long-term debt. Therefore, the secondary capital market, security brokers, are interested in purchasing this long-term debt from the banks and selling them on the open market as a government security.

The GLGP is very attractive to the financial community and feel the greatest problems are in the time consuming and delaying negotiations and review processes.

The GLGP is looked upon as any other type of finance and investment arrangement would be and the loan is analyzed using the same criteria as those without a government guaranty. Financial institutions assess the project as they would any other investment in terms of risk and meeting necessary goals for project success. None were willing to finance a geothermal project without the guaranty. Lenders agree that the GLGP is a tool for the smaller firms. The banks are fully aware 
Figure 7. Lending Institutions and Their Interest in ERDA's Loan Guaranty Programs.

\begin{tabular}{|c|c|c|c|c|}
\hline & $\begin{array}{l}\text { Primory } \\
\text { Lenders }\end{array}$ & $\begin{array}{l}\text { Concuit to } \\
\text { Secondory } \\
\text { Market }\end{array}$ & $\begin{array}{l}\text { Secondary } \\
\text { Market } \\
\text { Purchosers }\end{array}$ & $\begin{array}{c}\text { No } \\
\text { Interest }\end{array}$ \\
\hline Commercial Bonks & $x$ & & & \\
\hline Sovings \& Loon Associations & & & $x$ & \\
\hline Mutual Sovings Banks & & & $x$ & \\
\hline Credit Unions & & & $x$ & \\
\hline Life Insurance Companies & $x$ & & $x$ & \\
\hline Privote Pension Funds & & & $x$ & \\
\hline $\begin{array}{l}\text { State \& Local Government } \\
\text { Employee Retirement Funds }\end{array}$ & & & $x$ & \\
\hline Other Insurance Companies & $x$ & & & \\
\hline Finance Companies & & & & $x$ \\
\hline Real Estote Investment Trusts & & & & $x$ \\
\hline Open-end Investment Componies. & & & & $x$ \\
\hline Money Market Funds & & & & $x$ \\
\hline Security Brokers and Dealers & $x$ & $x$ & & \\
\hline individuals & & & $x$ & \\
\hline
\end{tabular}

Source: Smith, Russell, et al, Financial Incentives Research and Lending Market Impact Analysis, 1977 , p. 3-9. 
that they risk little or nothing in terms of dollars. They feel responsible and would not lend on a project they knew was going to default; but there is nothing to stop them from doing this under the GLGP.

Author's Evaluation

The program has not met its original expectations, nor has it met the objectives for which it was instituted. There remains about six more years but if the slow start and poor preparation are indications of what will be for the remainder of the GLGP, the industry will not respond.

The GLGP may make an unprofitable project profitable because of the high leverage and retention of full interest. The program is useful for those types of projects and also for a smaller firm that cannot raise the needed capital internally. It can be especially significant for field development and power plant construction where large sums of money are needed.

The financial community will not make a loan on these projects without the guaranty. The market for the GLGP is excellent and several banks are very interested in promoting the program.

The program has a number of enormous problems which must be alleviated before there will be an increase in the number of applicants. 
The lack of response to the program may be attributed to elements directly related to it: a) operating procedures, b) rules and regulations, c) application requirements, d) cost in dollars and time in preparing an application, e) processing and reviewing procedures, f) lack of well-defined criteria for obtaining a guaranty, and g) different interpretations and philosophies among DOE divisions. More significant are the external factors that have hindered the development of the geothermal industry, regardless of the availability of loan guaranties: legal, institutional, technical, economic, and political barriers. The uncertainties associated with the resource due to lack of historical experience and the problems in developing a new industry have affected, to some degree, the utilization of the loan guaranty program. The environmental regulations and reporting requirements do not prevent or limit the use of the program but impedes efficiency, is time consuming, and constrain geothermal resource exploration and development regardless of available financing. If these procedures are not streamlined and made more efficient, the industry will neither realize its potential nor meet the goals the federal government has set. The loan guaranty program is impeded by the general lack of activity in the industry due to these obstacles and not necessarily by the lack of desire or need to use such a program. 
The processing and reviewing of loan guaranty applications has been a major problem for the program. There is a great need to establish a process of reviewing and approving applications. The reviewing has been a time-consuming effort and no procedure has been implemented to expect an improvement will be forthcoming. SAN and HQ are not in agreement of what each other's role should be in the program. It has not yet been determined which divisions of DOE will have responsibilities for loan guaranties. Some personnel at HQ believe that they need to review the applications because the SAN review is inadequate. They feel that the applications sent to HQ do not supply sufficient data and many questions need to be answered before they can make any recommendations. Although the applications are reviewed at HQ, it has not yet been established whether or not their concurrence with the recommendation from SAN is necessary for approval. It is also necessary to establish the authority who has final approval and whether non-concurrence by another party can be overruled. Since only three applications have undergone this review, it is difficult to be conclusive in making a determination on the adequacy of SAN's review. Two applications were put into one review package, CUI and GFP, and apparently these were rushed in order to finish the process before the ERDADOE transition. Therefore, the quality of the senior staff review may have suffered. 
The SAN staff had to look at new issues not previously encountered. The legal review staff had no previous dealings with title search, leasing practices, environmental legalities, corporate issues, etc. The staff was geared to procurement and government contracts and not the workings of a loan guaranty program. This seems to be a problem at all levels. It is a new type of program and has never been used before the GLGP. Procedures defining the purpose and scope of the review had not been drafted. Preparation for the review of loan guaranty applications was either minimal or non existent. Time lost here has also added to the overall ineffectiveness of the program.

The quality of the applications and the information submitted have been a big problem. This can account for some of the lost time in reviewing applications. The applicants, not always familiar with geothermal resources, come from different industries. They do not always have expertise available for the technical or resource information and therefore do not always know what is required. Many of the applicants are not engineers or scientists, nor are they competent in the finance and banking aspects. Applicants may try to submit less than is required. The GLGP represents, for some, an easy way to make money, and are trying to put together deals to take advantage of the program. This is 
a problem for the program and unless applications for legitimate projects are submitted by responsible parties, the program will have little impact or credibility. The applicant may not understand what is needed or may wish to hold back information. For this reason, the quality of applications is highly variable.

There is also a need for a policy on the stage of exploration at which an application should be submitted. The applicants should be aware of what type of exploration is acceptable for obtaining a loan guaranty.

The USGS staff works very closely with SAN and has had no contact with $\mathrm{HQ}$. In discrepancies concerning resource assessment between the applicant and USGS, the USGS assessment is honored. Professional disagreement among geologists, geophysicists, etc., is not uncommon and this problem has not been resolved with respect to the GLGP. Consideration is being given for using private industry for this job. There exists feeling in government and industry that the USGS is not the most efficient means of handling the evaluation and that they do not deal with risk and business decisions much needed in the evaluation.

Time constraints have also posed a problem for USGS. The workload at the USGS is heavy and it does not allow enough time for the GLGP to be completed in the time SAN would like, 
three weeks; when leasing schedules come up time is more constrained according to the USGS.

Several issues evolve around the use of consultants. The consultants had to demonstrate their capabilities, but it is not clear which of them will be used. The information required for submission to the consultants and what was expected in return seems to have been a problem. The possibility of using private industry to do all of the reviewing is being contemplated. A policy must be established on possible conflicts of interest in this regard.

Because priority is given to small firms, according to the U.S. Department of Commerce's publication of government procurements (February 1978), "\$2l million in guaranties is reserved exclusively for small companies," but not limited to this amount. This raises the issue of who will be the benefactor of the loan guaranty program. The question of whether the small independent firm or the large integrated firm acquiring loan guaranties is most efficient and necessary. The implications of each are different as is their impact on the development of the geothermal industry. The question of if the program increases competition by lowering the barriers to entry is outside the scope of this paper, but must be considered by government agencies, especially in light of other guaranty programs. The GLGP program has not 
been in operation long enough to see where it will be most used and by whom.

Problems and ensuing delays have affected the Dry Creek, GeoCal, Burbank, Diablo, and NCPA applications. The author has drawns some conclusions about the fate of these applications based on personal contact with some of the parties and the author's own analysis of the situation. It is doubtful that the GeoCal, Diablo or NCPA/RFL applications will be completed. Long delays for Dry Creek and Burbank are eminent. In summary, considering the status of these applications and the length of time they have been at SAN, none seem very promising.

Problems of the GLGP

Numerous issues concerning the GLGP and therefore its ability to have an impact on geothermal development are listed below:

1. Mismanagement of the program, lack of financial and legal expertise.

2. Promotion, education, and, in general, public relations for increasing interest need to be further exploited.

3. Differences of opinion between consultants.

4. Differences of opinion between HQ and SAN.

5. Lack of communication between HQ and SAN. 
6. Friction and areas of conflict between SAN and HQ.

7. High cost of application $(\$ 40,000-\$ 100,000$ and higher).

8. Time in reviewing applications.

9. Lack of established and standardized procedures for reviewing applications.

10. Equity: What qualifies and determination of value of property (leases) and other assets.

11. Quality of applications.

12. Changing staff.

13. Long concurrence chain.

14. Industry concern about proprietary information and loan being non-recourse, associated only with the assets of the projects.

Where are the Applicants?

Some feel that it is only a matter of time before the GLGP "takes off," while others think this program is not what is needed because the firms who have the capital and expertise to develop the resource will not use the GLGP.

The following are cited as reasons for the lack of response to the program:

1. equity is difficult to raise for some applicants,

2. reluctance to get involved with federal government,

3. high cost of applications, 
4. waiting to see response to applications pending, and 5. concern about nonrecourse ard proprietary data.

The author feels these arguments lack substance. The well-established resource companies have enough capital sunk into leases to constitute the equity requirement. Response to cost-shared programs is far greater and this involves disclosure of proprietary data. It seems if money is free, the incentive is greater.

There exist many situations external to the program itself that are obstacles to its impact. The potential for such a program seems greater than its actual performance, although these problems may not have received the amount of deserved attention until such a need arose. Possibly the GLGP has had an impact on some of these "external" factors and thereby will promote development of geothermal resources. The GLGP is a subsidy for the industry. The government is helping to promote private industry by committing themselves to repay loans in default. It is extremely attractive economically and financially. The firm does not have to use its own funds for a project financed in this way. This allows capital flow into other projects and also reduces the risk to the firm. The program has not brought about any developments or projects that would not have been financed by other means, although the GLGP may have speeded up the process. 


\section{CONCLUSIONS AND RECOMMENDATIONS}

The Geothermal Loan Guaranty Program has not had an impact on developing geothermal resources in the short term, although it could potentially stimulate development of geothermal energy. The impact could be more than the addition of electricity, it could mean increased awareness of the potential and utilization of the resource, improvements in technical areas, and the lessening of the reliance on fossil-fuels, especially petroleum.

With only three loan guaranties approved and an additional six, of which five have been at SAN for over a year, the impact and activity are minimal. The program was off to a bad start from the beginning and problems have continued hindering its performance. The staff had little or no prior exposure to geothermal resources and the GLGP was the first loan guaranty program for energy resources. The preparation for implementing the program was not sufficient. Government officials claims this was due to the newness of the program, needed flexibility, and unknowns concerning applicants, projects, and needs. 
The use of this type of support is increasing and needs to be examined for its potential success and impact on the development of energy resources and technologies. External factors, operation and management of these programs will determine their ability to meet the expected objectives and goals.

The Geothermal Loan Guaranty Program has not met the expected $\$ 200$ million per year in loan guaranties or 20 applications per year expected to be received by the san Francisco Operations office in Oakland, California administering the program. Table 12, Geothermal Loan Guaranty Applications, was used for budgetary purposes and is very optimistic. Some of the applications may never be submitted; applicants have many prerequisites prior to submission of the application. If the applications are submitted, it does not insure a loan guaranty will be granted or that the project is feasible. A false, optimistic impression of the use of the program may be gotten from this list.

The GLGP is plagued by the general state of the industry, the lack of activity, and the many legal, institutional, and technical barriers.

The GLGP may have negative impact on geothermal development. The GLGP may delay the normal process of exploration 
and development by offering more attractive financing arrangement. If a firm can use borrowed money with a lower risk, possibly they would delay a project until such time that they could obtain a federal loan guaranty.

The GLGP may also make it more difficult to obtain capital by conventional means. If lenders can make loans with federal guaranties, they may be reluctant to make them without the guaranty. The author understands that at this time lenders have stated they will not make loans for geothermal projects but possibly the GLGP would delay the establishing of lending without guaranties. This could be of significance especially if the program is extended beyond 1984 .

The introduction of other loan guaranty programs, with greater budget appropriations, may increase the competition to obtain loans under the GLGP.

The GLGP may be having an indirect impact on geothermal development. By its very existence, it is generating greater interest and industry may be taking a closer look at the resource than before. The GLGP may also lower the barriers to entry and increase competition by increasing the number of firms in the geothermal industry.

The low priority afforded geothermal resources and the GLGP in government and private sectors contributes to the 
lack of response to the program. A need for promotion and education of the GLGP exists. Apparently SAN did not conduct a mass mailing of the newer guidelines, as some industry representatives did not receive them. A mass mailing of the guidelines would be an effective way to educate the industry and promote the program. This need is often demonstrated by the misconceptions held about the GLGP. These include: a) uncertainty that this is a non-recourse loan, one associated only with the assets of a particular project, b) concern about maintaining proprietary information confidential, and c) belief that only leases with deep wells will be considered for a loan guaranty.

If the latter is correct, it is in complete noncompliance with the law (P.L. 93-410) which specifically states lease acquisition and exploration, including thermal gradient and geophysical surveys, are allowable under the GLGP. The GLGP rules and regulations are not consistent with the purpose outlined in the legislation (P.L. 93-410). This act did not assign priorities and clearly stated the GLGP was to be used for lease acquisition and wildcatting. The author believes these will not be approved for loan guaranties by HQ.

The Geothermal Loan Guaranty Program differs from the demonstration program in that the capital subsidy is free 
for a demonstration and not for a loan guaranty. The loan guaranty is directed at capital markets in trying to bring about a normal environment for lending in geothermal utilization. The objectives of the GLGP and the demonstration program is similar in that they are both directed at stimulating the industry but it remains as seen and is debatable which will prove more effective. There also exist differences between the two which are suppoed to serve different objectives. The proponents of the demonstration plant believe it will be a prelude to the GLGP, as it is believed the Reservoir Case History Program will also function.

It is the opinion of the author that if the construction of power plants using geothermal resources is profitable, private industry will build them; and if it proves to be unprofitable, they will not. The demonstration program does little to improve the economics and also accomplishes little toward resolving the legal, political, and institutional problems that plague the industry. It also does not obliterate barriers to capital formation in this industry. Even if technical and reservoir uncertainties are laid to rest, many issues must be resolved before we will see large scale use of geothermal resources. The author proposes that given the abatement of the institutional barriers, the granting of tax subsidies, the streamlining of environmental 
requirements and leasing procedures, the industry would stand on its own without the direct subsidy a demonstration plant represents.

If projects economics are more attractive and competition increases for capital--if management can get a higher rate of return from coal leases and still exploit their geothermal leases with lower risk and little of their own money--firms will begin to use to GLGP. Once one firm uses it and thereby gain a competitive advantage, others will follow.

The impact of the GLGP on geothermal exploration and development has been negligible so far. In order to evaluate the impact of the GLGP, it should be determined whether or not projects financed with a federal loan guaranty would have been undertaken without the guaranty. It must also be determined what is meant by impact and the significance of any change in status. It may be that any additional use of geothermal energy with the use of the GLGP constitutes an impact. The author is of the opinion that most of the projects undertaken with a GLGP would have, at some later time, been done without a federal loan guaranty. Beside speeding up the small amount of activity in the industry, the GLGP has had a positive impact on lenders. The GLGP has made the financial community aware of the 
potential market for capital in geothermal and become familiar with the resource and its unique qualities.

The impact of the GLGP on geothermal exploration and development will continue to be negligible until the problems surrounding the program and the resource are aleviated.

\section{Conclusions}

It is this author's opinion that if the government really wants to promote geothermal development, it should stop creating new programs until either improvements or termination of the ones already existing occur. The federal government, through the Department of Energy, should cease subsidizing the industry. If the legal and institutional barriers were lowered, capital flow into geothermal would be evident. Capital availability would be in the more conventional manner and not through government programs. Government intervention has made it uneconomic for firms to dare invest their own equity in a venture when their competition is being subsidized.

Government activity in geothermal should be limited to research and development for exploration methods, drilling technology, data management and dissemination, leasing, streamlining regulations, and promoting formulation of state and local legislation. Business and government do not operate with the same objectives and constraints. Government 
actions can be attributed to political ambitions, national interest, and social benefit; this is not to say that industry disregards these facts but more often seeks larger market shares, integration, increased profits, prestige, and more often deals with real risk situations and real dollars.

Let government support research aggressively, especially on unconventional sources of energy. But the government should "keep out of the development and production phases of energy supply."

\section{Recommendations}

The author has attempted to make recommendations believed to be helpful in making the GLGP a better program and attracting applicants. The author proposes these be implemented for the remaining life of the program and that it not be extended beyond september 3, 1984. Several issues must be resolved and policies formulated. These issues are presented herewith in order to stimulate discussion hopefully leading to their resolution.

1. Promotion, public relations, and education need to be further exploited.

SAN conducted seminars for potential borrowers and lenders almost two years ago, during the summer of 1976 ; possibly this should be repeated. Emphasis at conferences, 
seminars, etc., should be on how an applicant can meet the criteria, what the requirements are, and problems, not simply a general overview. Specifics must be addressed. There should be a mass mailing of promotional material and application guidelines. Misconceptions could be eliminated through this means.

2. A schedule of events should be outlined by which SAN will have increased authority and also reduces the number of people reviewing the applications. Review conducted by SAN staff and outside consultants, and then only by the office of the Controller and possibly General counsel at HQ would reduce review time substantially. The proximity of the reviewers would also facilitate the process.

3. A policy should be formulated determining what stages of geothermal development the GLGP will be used for: lease acquisition, exploratory drilling, development drilling, or power plant construction. A percentage of available dollars of budgetary authority should be allocated to each category in order to reach an optimal solution that will generate the greatest benefit for the given level of cost. Alternative non-electric utilization could possibly be part of an application if temperatures prove to be insufficient for electric generation. 
4. There is too little communication between SAN and HQ. SAN should be advised of all policy decisions and discussion concerning the GIGP. Areas of conflict and the friction and competitive attitude between the two over this program must be eliminated. This has slowed down any progress toward resolving the problems the program has.

5. Policy issues must be decided in the following areas:

a. Multiple site applications: do these have to be related projects or dependent?

b. Will market value or cost of leases and other assets qualify as the equity share?

6. Establish procedures and guidelines for reviewing at HQ. The same staff should see all applications; they should not be "farmed out" to different staffs with each application.

7. Concurrence and final approval authority must be assigned. This authority should be given to the Deputy Secretary or some other staff who would be able to overrule a nonconcurrence of the Assistant secretaries. The author does not believe all parties need to concur with a recommendation in order to reach a final decision on a project.

8. The Division of Geothermal Energy should disassociate itself from the GLGP. Only those divisions who were given 
authority under DOE organization can work to change and improve the program and therefore should be the only ones involved in this process.

9. The Institutional Barriers Panel of the Geothermal Advisory Council should concern itself with the larger problems of legal issues, leasing policies, legislation, and environmental regulations which would also impact the GLGP. There is little or nothing they can or should do with the GLGP. Too many issues need resolving before major institutional changes can occur.

10. A policy decision on the resolution of differences of opinion between SAN, HQ, applicants, and consultants is needed. If a project is rejected on the basis of a poor evaluation of the project in any one area (i.e., management, economics, technical, reservoir temperature, etc), a third evaluation should be made by an outside party, not by the government's or applicant's consultants.

11. A policy on conflict of interests with respect to applicants and consultants. For example, if a private firm is enlisted to evaluate an application and an employee or client has interests or the firm applying for a loan guaranty, another consultant should be sought.

12. Consultants to be used for evaluating applications must be chosen and be consistent with each one. Private firms may be engaged for this rather than the USGS and ORNL. 
The use of the USGS seems questionable considering their time and workload constraints within which they work. It is also suggested that private industry be engaged because they have better access to information and deal with risk and investment as an everyday occurrence. Private industry deals and thinks in terms of real dollars and government has less tendency toward this.

The Geothermal Loan Guaranty Program has until September, 1984, about five and one-half years, to get organized and have an impact on geothermal exploration and development. If change in policy and review procedures and the organizing of DOE do not take place soon, the GLGP will never "take off." The author does not foresee an increase in the number of applications or loan guaranties in the next year or two. This is due to the fact that organization and implementation take a long time in the federal government and preparation of applications is also a time consuming endeavor.

Loan guaranties are a new form of government support in the energy field and many issues warrant further investigation: the impact on capital markets and investments, the effect on allocation and development of resources, interest rates, and competition. 


\section{REFERENCES}

Aidlin, Joseph W., United States law as it affects geothermal development, Proceedings: Second United Nations Symposium on Development and Use of Geothermal Resources, May 1975.

Barnea, Joseph, Multipurpose geothermal resource development-an overview, Proceedings: Second U.N. Symposium on Development and Use of Geothermal Resources, May 1975.

Barr, Ronald C., Geothermal energy and electrical power generation, Proceedings: Second U.N. Symposium on Development and Use of Geothermal Resources, May 1975.

Barrager, Stephen M., and Daniel J. Quinn, Economic analyses of geothermal energy development in California, stanford Research Institute, Vol. 2. Cost/Benefit Analysis of Government Program Alternatives Regarding Hot Water Geothermal Power, US DOE Contract NO EY-76-C-03-0115-108, CA, May 1977.

Bierman, Sheldon, and Gaillard T. Hunt, ERDA leaves it lay, The Nation, November 12, 1977, pg. 487-489.

Bierman, Sheldon, Geothermal energy and the bulk electric power and petroleum industries, Draft, Volumes I, II, III, IV, NSF Grant No. Apr 75-18321-A02, February 1977.

Bierman, Sheldon, Innovation versus monopoly: geothermal energy in the west, Final Report, US ERDA, Division of Geothermal Energy, July 1977.

Birsic, Rudolph J., More about geothermal steam or the hottest energy prospect ever, Fullerton, CA, Oct. 1976.

California State Division of Conservation, Draft report of the state geothermal task force, Sacramento, CA, Nov. 2 , 1977.

Eaton, William W., Geothermal energy, U.S. ERDA, Washington, D.C.

Friedman, E., and S. Pond, Legal and institutional impediments to geothermal energy resource development, a bibliography, Mitre Corporation for ERDA-DGE/2268-1, McLean, VA, March 1977. 
Geothermal Resources Council, Proceedings: direct utilization of geothermal energy: a symposium, San Diego, CA, Jan. 31-Feb. 2, 1978 .

Geothermal Resources Council, Proceedings: special short course No. 4, Denver, CO, April 8-9, 1976.

Geothermal Resources Council, Proceedings: geothermal resources: survey of an emergency industry, Houston, TX, Dec.12-13, 1977.

Greider, Robert, Status of economics and financing of geothermal energy power production, Proceedings: Second U.N. Symposium on Development and Use of Geothermal Resources, May 1975.

Greider, Robert, Economic considerations for geothermal exploration in the western United States, Proceedings: symposium on geothermal energy and colorado, Colorado Geological Survey, 1974, pgs. 45-60.

Howard, J.H., Editor, Present status and future prospects for nonelectrical uses of geothermal resources, Lawrence Livermore Laboratory, Univ. of California/Livermore, CA, Oct. 3, 1975 (NATO CCMS Report No. 40, Prepared for ERDA).

Kitchen, Gerald J., Geothermal leasing practices, Proceedings: Geothermal Resources. Development Institute, Salt Lake City, UT, January 27-28, 1977.

Knutsen, Corey A., Benefits of stimulating geothermal energy development with tax and research subsidies, Pacific Northwest Laboratories, ERDA Contract E(45-1)-1830, August 1976.

Koenig, James B., Anderson, David N., and Huttrer, Gerald W., Exploration and development of geothermal resources in the United States, Proceedings: Second U.N. Symposium on Development and Use of Geothermal Resources, May 1975.

Mahoney, Denis J. and A. Charles Bargert, Economic impact of geothermal development, Sonoma \& Lake Counties, CA, Spring 1977.

Massachusetts Institute of Technology, Government support for the commercialization of new energy technologies, MIT Energy Laboratory, Policy Study Group, Cambridge, MA, Nov. 1976 . 
McCabe, B.C., Aidlin, J.W., and Falk, Harry W. Jr., Practical aspects of a viable geothermal energy program, Proceedings: Second U.N. Symposium on Development and Use of Geothermal Resources, May 1975.

McNamara, Jack, Horizontal divestiture and the geothermal industry: a case of mistaken identity, mimeographed.

Morrison, Richard, A comparative study of selected federal government guarantee programs, Presidential Interchange Executive, Office of Commercialization, ERDA, December, 1976.

Olson, Harry J. and William M. Dolan, Geothermal energy--an industry appraisal, Mining Congress Journal, March 1976 , pg. $18-21$.

Palmer, J.D., Howard, J.H., and D.P. Lande, editors, Geothermal development of the Salton Trough, California and Mexico, Lawrence Livermore Laboratory, Univ. of California, Livermore, CA, April 1, 1975.

Post, Lee, Preliminary Boise geothermal energy systems plan, City of Boise Energy Task Force, Boise, ID, April 1977.

Ramachandran, G., Economic analyses of geothermal energy development in California, Stanford Research Institute, Vol. 1, Menlo Park, CA, (US DOE Contract No. EY-76-C-030115-108), May 1977.

Rocky Mountain Mineral Law Foundation, Proceedings: Geothermal Resources Development Institute, Salt Lake City, UT, January 27-28, 1977.

Sacarto, Douglas M., State policies for geothermal development, National Conference of State Legislatures, Denver, Colorado, 1976.

San Diego Gas and Electric, Heber geothermal demonstration plant fact sheet, San Diego, CA, January 3, 1978.

Schlauch, Paul J., Geothermal resources joint ventures, Proceedings: Geothermal Resources Development Institute, Salt Lake City, UT, Jan 27-28, 1977. 
Smith, J.L., C.F. Isselhardt, and J.S. Matlick, Summary of 1976 geothermal drilling--western United States, Geothermal Energy Magazine, Vol. 5, No. 5, May 1977, pg. 8-17.

Smith, Russell F., Bryant, Patricia S., Conr, Edward E., and Paul C. Kouchoukos, Financial incentives research and lending market impact analysis, Bradford National Corporation, Prepared for ERDA, N.Y., N.Y., August 1977.

Stone, Christopher, and MCNamara, John, Geothermal energy and the law, Vol. II: A Preliminary Analysis of Federal Tax Reform on Geothermal Energy Development in the United States, Draft Report, Univ. of Southern California Law Center, Los Angeles, CA 1975.

Tarlock, Dan A., and Walter, Richard I., An environmental overview of geothermal resources development, Proceedings Geothermal Resources Development Institute, Salt Lake City, UT, Jan 27-28, 1977.

Trower, E. Dale, An overview of the California permitting process, Proceedings: Geothermal Resources Development Institute, Salt Lake City, UT, Jan. 27-28, 1977.

U.S. Congress, Public Law 95-91, Department of Energy Organization Act, August 4, 1977.

U.S. Congress, Public Law 91-581, 9lst Congress, S. 368, Geothermal Steam Act of 1970, December 24, 1970.

U.S. Congress, House of Representatives, Loan guaranties for new energy technologies - capital formation, Committee on Science and Technology, No. 94-1170, May 16, 1976.

U.S. Congress, House of Representatives, Geothermal energy research, development, and demonstration act of 1974, Oversight Heating-Loan Guaranties Hearing before the Subcommittee on Energy Research, Development, and Demonstration of the Commitee on Science and Technology, Ninety-fourth Congress, First session, Oct. $1,6,1975$.

U.S. Congress, House of Representatives, Energy from geothermal resources, Report prepared by the congressional Research Service, Science and Astronautics Subcommittee on Energy, 93rd Congress, 2nd Session, 1974. 
U.S. Congress, House of Representatives, Loan guarantees for demonstration of new energy technologies, Report No. $94-1170$, May 16, 1976.

U.S. Congress, House of Representatives, Hearing before the Subcommittee on energy research, development, and demonstration of the committee on science and technology, Oversight Hearings on Public Law 93-410, January 20, 1976 .

U.S. Congress, United States Senate, Petroleum industry involvement in alternative sources of ènergy, Committee on Energy and Natural Resources, Subcommittee on Energy Research and Development, Publication No. 95-54, September 1977 .

U.S. Congress, United States Senate, Loan guarantees and the federal budget, Committee on the Budget, Staff Working Paper, Draft, November 23, 1976.

U.S. Congress, United States Senate, Geothermal energy act, Hearing before the Subcommittee on Water and Power Resources of the Committee on Interior and Insular Affairs on S.2465, November 7, 1973 .

U.S. Congress, United States Senate, The potential for energy production from geothermal resources, Subcommittee on Water and Power Resources, 93rd Congress, lst Session. 1974.

U.S. Congress, United States Senate, Geothermal energy development, Hearing before the subcommittee on Energy Research and Water Resources of the Committee on Interior and Insular Affairs, Idaho Falls, ID, October $17,1975$.

U.S. Congress, General Accounting office, Problems in identifying, developing, and using geothermal resources, RED-75-30, March 6, 1975 .

U.S. Dept. of Energy, Interim Management Directive, DOE Organization, Serial No. 27, IMD No. 0102, september 30 , 1977 .

U.S. Department of Energy, Interim Management Directive, Authority delegations, and order of secretarial succession in the department of energy, Serial No. 33, IMD No. 0204, October 3, 1977. 
U.S. Department of Energy, Budgetary implications of the President's energy policy, overview, and perspective, April 20, 1977 .

U.S. Department of Energy, Loan guaranty programs: energy applications, prepared by Harbridge House, Inc., 1976.

U.S. Department of Energy, Approval procedure for department of energy loan guaranties, Interim Management Directive, 1977.

U.S. Department of Energy, Institutional barriers to geothermal energy development, A report by the Institutional Barrier Panel of the Geothermal Advisory Council, June $30,1976$.

U.S. Department of Energy, Institutional barriers to geothermal energy development, second report of the Institutional Barrier Panel of the Geothermal Advisory Council, Dec. 21, 1976.

U.S. Department of Energy, Executive Office of the President, Energy policy and planning, DOE Activation Task Force, Organizational Integration Working Group, September 13, 1977 .

U.S. Department of Energy Research and Development Administration, Division of Geothermal Energy, Definition report, Geothermal Research, Development, and Demonstration Program, Washington, D.C., October 1975.

U.S. Department of Energy Research and Development Administration, Division of Geothermal Energy, Guidelines to the preparation of environmental reports for geothermal development, February 1977.

U.S. Department of Energy Research and Development Administration, Geothermal loan guaranty application guidelines, San Francisco Operations office, Oakland, CA, December 1976 .

U.S. Energy Research and Development, Division of Geothermal Energy, First annual report, ERDA 77-9, April 1977.

U.S. Energy Research and Development Administration, A national plan for energy research, development, and demonstration: creating energy choices for the future, Volume 2: Program Implementation, ERDA 76-1, 1976. 
U.S. Energy Research and Development Administration, Minutes, Advisory Committee on Geothermal Energy, Open Meeting, Washington, D.C., Jan. 10, 1977.

U.S. Energy Research and Development Administration, Minutes, Advisory Committee on Geothermal Energy, Open Meeting, Southern California Energy Program office, Los Angeles, CA, Sept. 16, 1976 .

U.S. Department of the Interior, Geological Survey, USGS assistance on the ERDA geothermal loan guaranty program, Interagency agreement, Reston, VA, Aug. 1977.

U.S. Department of the Interior, U.S. Fish and Wildlife Service, Geothermal handbook, Geothermal Project, Office of Biological Services, NP-21172, June 1976.

Ward, Robert P., Financial and marketing requirements for geothermal development, MBA Thesis, U.C., Berkeley, June 1977.

Weinstein, David, Gordon, Theodore, J., Maslan, Frank, Legal aspects of geothermal energy development, Proceedings: Second U.N. Symposium on Development and Use of Geothermal Resources, May 1975.

White, D.E. and Williams, D.L., Editors, Assessment of geothermal resources of the United States, Dept. of the Interior, Geological Survey, Circular 726, 1975 .

Woods, John, Financing the geothermal industry under the geothermal loan guaranty program, Bank of Montreal, 1977 (mimeographed). 


\section{BIBLIOGRAPHICAL INFORMATION}

* Abbott, Robert, 1977, Earth Energy, Inc., San Francisco, California.

Barnes, Burton, 1977, DOE, Division of Geothermal Energy, Washington, D.C.

Barr, Ronald, 1977, Earth Power Corporation, Tulsa, oklahoma.

Bernard, Peter, 1977, DOE, San Francisco Operations Office, Oakland, California.

* Bloom, Larry, 1977, Federal Financing Bank, Treasury Department, Washington, D.C.

Boren, Ken, 1977, GeoCal, Geo Products Corporation, Oakland, California.

* Bowen, Richard, 1977, RLK and Company, Portland, Oregon.

Brechtal, Susan, 1977, DOE, San Francisco operations office, Oakland, California.

Bresee, James, 1977, DOE, Division of Geothermal Energy Washington, D.C.

Bromberg, Kenneth, 1977, DOE, San Francisco Operations Office, GLGP, Oakland, California.

Brubaker, Gerald, 1977, Council on Environmental Quality Washington, D.C.

Butler, David, 1977, Chevron Resources Company, San Francisco, California.

Castellanos, Peter, 1977, Diablo Exploration, Oakland, California.

Chew, Laurie, 1977, Bank of America, Los Angeles, California.

*Corman, Dale, 1978, O'Brien Resources, Kentfield, California.

Crane, David, 1977, DOE, Office of the Controller, Washington, D.C.

Crosby, Gary 1978, Phillips Petroleum, Del Mar, California.

Cullen, Joe, 1977, DOE, San Francisco operations office, GLGP, Oakland, California.

* Telephone communication. 
* Dieckman, John, 1978, Getty Oil Company, Bakersfield, California.

Dolan, William, 1978, Amax Exploration, Inc., Denver, Colorado.

* Falcone, Dominic, 1977, Geothermal Resources International, Inc., Marina del Ray, California.

Falick, Larry, 1977, DOE, Commercial Applications, Washington, D.C.

* Floyd, Acy, 1977, Southern California Public Energy Corporation, Burbank, California.

Forsberg, Kristine, 1977, DOE, Division of Geothermal Energy, Washington, D.C.

Fri, Robert, 1977, Attorney-at-Law, Washington, D.C.

Garson, Henry, 1977, DOE, Washington, D.C.

Greider, Robert, 1977, Thermex, Intercontinental Energy Corporation, Denver, Colorado.

* Harvego, Lloyd, 1978, California Department of Water Resources, Sacramento, California.

Heinzelman, Claire Carlson, 1977, Thermal Power Company, San Francisco, California.

Howell, David, 1978, Republic Geothermal, Inc., Santa Fe Springs, California.

Ingraham, Norman, 1977, Northern California Power Agency, Santa Clara, California.

Isherwood, William, 1977, U.S. Geological Survey, Palo Alto, California.

Isselhardt, Courtney, 1978, Republic Geothermal, Inc., Santa Fe Springs, California.

* Jenkins, Claude, 1978, Aminoil, Santa Rosa, California.

Kuhn, Edwin (AI), 1977, DOE, Office of Conservation and Solar Application, Washington, D.C.

LeGrown, Joe, 1977, DOE, San Francisco Operations Office, Oakland, California.

* Telephone communication. 
Long, William, 1977, Amax Exploration, Denver, Colorado .

* Lyon, Ken, 1978, Morrison-Knutsen, Boise, Idaho.

* Martinez, Art, 1978, Public Service Company of New Mexico, Albuquer.que, New Mexico.

* McNamara, John, 1977, Univ. of Southern California, Los Angeles, California.

Myerson, Edward, 1977, DOE, Commercial Applications, Washington, D.C.

* Nash, Ray, 1978, Geothermal Food Processors, Inc., Turlock, California.

Nash, Ed, 1978, U.S. General Accounting Office, Los Angeles, California.

Nastich, Diane, 1977, DOE, San Francisco Operations office, GLGP, Oakland, California.

* Newton, Christopher (Kit), 1977, Pacific Gas and Electric, San Francisco, California.

O'Donnell, Mike, 1978, Geothermal Kinetics Inc., Phoenix, Arizona.

Otte, Carel, 1978, Union Oil Company, Los Angeles, California.

* Perry, Bernard, 1978, Southern California Edison, Rosemead, California.

Ponder, Stephen, 1978, Thermogenics, Inc., San Francisco, California.

* Porter, Keith, 1978, Sierra Pacific Power Company, Reno, Nevada

Randall, Walter, 1978, Geothermal Resources International, Inc. Marina del Ray, California.

* Richards, Dick, 1978, Sierra Pacific Power Company, Reno, Nevada.

* Rodzianko,Paul, 1978, Geothermal Energy Corporation, New York, New York.

* Telephone communication. 
Rogers, Herbert Jr., 1978, Rogers Engineering, San Francisco, California.

Root, Thomas, 1977, O'Connor and Miller, Denver, Colorado. Rudisill, Jacob, 1977, Thermal Power Company, San Francisco, California.

Russell, Rollin, 1978, McCulloch Geothermal Corporation, Los Angeles, California.

Salisbury, John, 1978, DOE, Division of Geothermal Energy, Washington, D.C.

Silverman, Mark, 1977, DOE, San Francisco Operations Office, GLGP, Oakland, California.

* Singer, David, 1977, Deuterium, Inc., White Plains, New York. Stone, Reid, 1977, U.S. Geological Survey, Palo Alto, California.

* Thomas, Craig, 1978, Merrill Lynch, San Francisco, California. Toms, Ron, 1977, DOE, Division of Geothermal Energy, Washington, D.C.

* Twogood, Donald, 1978, Imperial Valley Irrigation District, Imperial, California.

* Valeo, Jim, 1978, Salomon Brothers, San Francisco, California. Vickers, Edward, 1977, Bank of America, San Francisco, California. Weaver, J.P., 1978, ZIA Corporłtion, Long Beach, California.

Woods, John, 1977, Bank of Montreal, San Francisco, California.

* Telephone communication. 


\section{IIST OF APPENDICES}

$\underline{\text { Page }}$

A. GAO Questionnaire 128

B. Designated KGRA's 136

C. Lease Sales as of December 31, 1977 141

D. Drilling in the western United States 1975-77

E. Firms Invovled in Geothermal Development

F. ERDA Budget for FY 76-78, 159

G. Geothermal Energy Research and Development, and Demonstration Act of 1974 (P.C. 93-410)-- 162

H. Geothermal Loan Guaranty Program Rules and Regulations-- 174

I. Amendments to the Geothermal Research, Development, and Demonstration Act

J. Geothermal Resources Development Fund Budget for Fiscal Year 1979

K. Loan Guaranty Application Form 191

L. Loan Guaranty Agreement 195 
APPENDIX A

GAO QUESTIONNAIRE 
1. Do you belleve the development of geothermal resources in the U. S. Is proceeding at a rensonable rate?

1. IT Yes

2. II :10

3. IT i!o opinion

If no.

$$
\begin{aligned}
& I T \text { Too slow } \\
& I T \text { soo fast }
\end{aligned}
$$

2. Through legislation in 1:74 and 1975, E:DA was assinged the responstbility for accelerating the development of geotherual resources in the U. S. To what degree has EDA andived tils goal? IT To a great extent T To a moderate extent IT To a slight extent I No progress IT ERra really can't accelerate develogment IT No opinion

3. That "should be" the Eederal Government's primary role in Lavaicuing geothermal energy? (Select the one which best represents jour thoughts)
a. I have primary responstuility for demonetration, technology More concern being givan to national energy needs than to econonic feasibility. development, and connercialization of geothermal resources.
b. IT be a partner in geotheralal devalopnent with other levels of Governuent and private iriustry. Sharing in the responstbillty for demcrstration, technology develmopinent and comerciallzation of geothemal resources.


c. IT hire a supportive position. Assisting private industry upon request or when the need for assistance is ident1fied. Having an active role in geotherial developnent prinarily by providing an environment conducive to commerclalization by making regulatory changes and providing certain financial incentives.

d. IT have nnly a resulatory role. Establishinj $\approx$ well-defined franework within which private industry must operate. Leaving all other asfiects of development to the private sector.

e. IT not become involved in geothermal development. I.e: private industry develop seotlecmul resources on its orm.

E. IT M opinton

4. Responsibility for geotheral resurce assessmert in the United States resides w1th the U. S. Geological Survey (USGS). How effective has USGS resource essess?ent work been?

$$
\begin{aligned}
& \text { IT Very effective } \\
& \text { IT loderately effectlve } \\
& \text { IT slightily effective } \\
& \text { IT Hot afiectiva } \\
& \text { IT Shouldn't ja uses responsibility } \\
& \text { IT Ho opirion }
\end{aligned}
$$

5. If you have had prior experlenses with oil and zas rescruce development, hois would you compre or rate USGs' assessment work in tiese ares. with its geothermal assess'jerts?

II Superior to oll and gas effort

$I T$ Same as oil and gas efforts

$I$ Inferior ti ofl and gas efforts

IT No opinion 
6. ERDA has_projected 3,000 megawatts of electric power production from geothermal resources by 1985 . What is your opinion of the potential for electric power production from geothernal by 1985 and 2000?

$$
\begin{aligned}
& 1985 \\
& 2000 \\
& \text { П } 0-1000 \mathrm{MW} \\
& \text { I } 0-1000 \text { SW } \\
& \text { I7 1,001-2000 MW } \\
& \text { IT 1,001-3,000 1.W } \\
& \text { I } 2,001-4,000 \mathrm{MW} \\
& \text { IT } 3,001-6,000 \mathrm{BN} \\
& \text { IT 4,001-6,000 MW } \\
& \text { IT } 6,001-10,000 \mathrm{MH} \\
& \text { I! } 6,001-10,000 \mathrm{MW} \\
& \text { IT } 10,001-100,000 \mathrm{IW} \\
& \text { IT 10,001 I nore INW } \\
& \text { II } 100,001-200,000 \mathrm{MW} \\
& \text { IT No opinion } \\
& \text { II 200,001 or more MT } \\
& \text { IT No optrion }
\end{aligned}
$$

7. What do you anticipate the contribution from your leases will be to this electric power production by 1985 iviN, and by 2000 MN?

8. Below are listed sone of the najor problens identified by varlous studles as 1ssues delaying the development of geothermal rescurces Please ind1cate how these issues impact on your development of geothermal resources.

\section{Issue}

Land leasing (acreage linitation, unftization,etc.) Permitting problems (drilling)

Environmental (reporting, environmental techology) Technical barriers (hardware for power conversion, scaling, etc.)

Tax laws (intangtble drilling costs, depletion) Financlal uncertainty \& risk (capital, bank loans) Resource uncertainty (reservoir life, etc.) Exploration (finding the resource) Electric utilities (reluctancy to develop or support)

Water use (obtaining water and pollution problems) Econonics (geothermal not competitive with other energy sources)

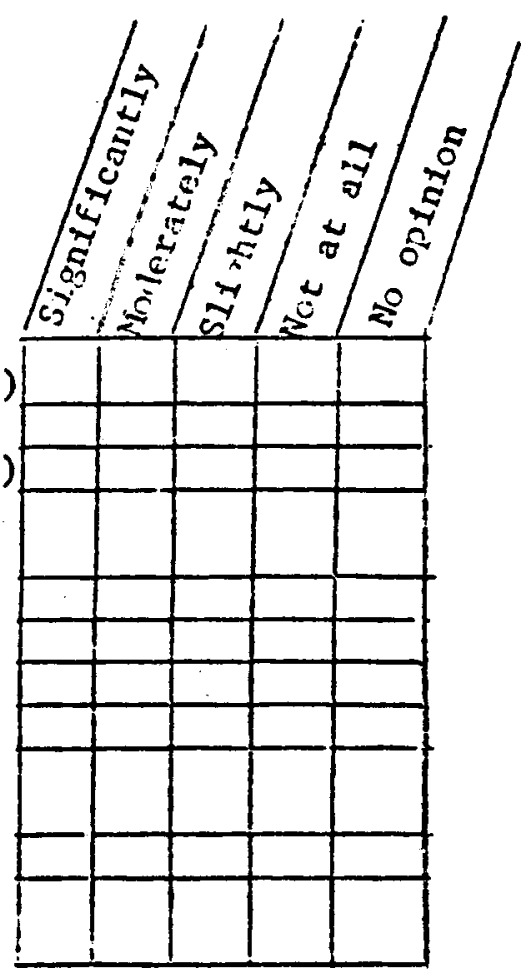


9. Tho (what) do you use as your prinary source of Information to keep abreast of current geothermal developments and advancements?
a IT ERDA
b. IT JGGS
c. IT State Agency (spectfy)
d. IT Research Institution (specify)
e. IT Generated in-house (orn resaarch)
f. I Member of private Industry (speciriy)
g. IT other (specify)

1). Do you belleve there is a need for increased information dissemtnation by the Federal Government on new technologies and what the Federal Government is doing to advance gæothermal?

T Considerable, hardly any tnformation currently avallable

$I$ Some, sufficient trade fournals, etc., Evallahle

$I$ Not at all - eno:igh is availabie

$I$ No opinion

11. What was the prinary reason you or your conpiny leared geothertual lands?

a. IT development - electric gower production

3. IT developient - nonelectric epplications

c. $T$ Investment

d. IT to explore and then lease to a developer

e. IT other (spectfy) 
12. Which types of geothernal resources are you leasing?

(Check more than one if necessary)
a. IT iry stean
b. IT hot water
c. IT hot dry rock
4. IT zeopressured
e. IT nagms
f. IT other (specify)
S. IT don't know

13. Please list how any acres of land your company has for reothermai developnent and approrinately what percentage of these lands are within known geotherial rasource areas (KGRA).

Federal
State
Private
Other (specify)
Total

\begin{tabular}{|l|l|}
\hline Acranre & $\%$ within KGEi 's \\
\hline & \\
\hline & \\
\hline & \\
\hline & \\
\hline
\end{tabular}


14. Approxinately how nuch money have you or ycur coapany spent for geothermal development (excluding lease paynents) in 1975, 1975 , and $1977 ?$

\begin{tabular}{|c|c|c|c|}
\hline Anount & 1975 & 1976 & 1977 \\
\hline Nothing & & & 17 \\
\hline Less than $\$ 10,0$ ? & & & \\
\hline$\$ 10,030$ to $\$ 93,999$ & & & \\
\hline$\$ 100,000$ to $\$ 299,939$ & & & \\
\hline$\$ 37,,(\})$ to $\$ 499,500$ & & & \\
\hline$\$ 50 r_{0}, 032$ to $\$ 350,899$ & 1 & & 1 \\
\hline$\$ 1$ alllion to $\$ 3$ alilicn & 1 & & 1 \\
\hline
\end{tabular}

15. Approxinately how wuch aney has been bur?etad for 19?3 !exaludin: lazse payments)?

II Nothiag

$I$ Less than $\$ 10,000$

II $\$ 109,609-\$ 299,290$

II \$300,000 - \$490,299

IT $\$ 500,720-\$ 909,939$

IT Wore than $\$ 3$ million 
16. DC you think there lo a nepf for FRTA's geuthermal loan guarantee program?

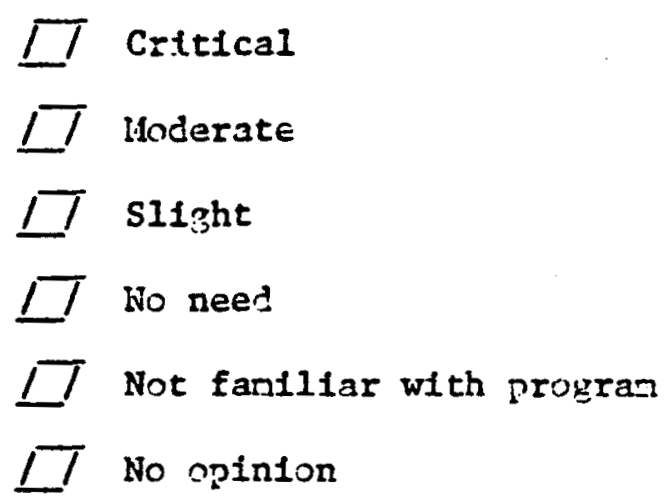

17. Are you or your company unable to raise capital to finance developrent of jeothermal resources?

$$
I T \text { Yes }
$$

18. Are you or your company planning to apply for a loan gunrantee?

$$
\begin{aligned}
& I T \text { Yes } \\
& I T \text { Uncertain }
\end{aligned}
$$

19. Federal regulations allow lessees to pool their resources, referred to as unitization, for geothermal resource developiant. Do you plan to pursue unitization with other lessees to devejop your geothermal leases?

$$
\begin{aligned}
& I T \text { Yes } \\
& I T \text { No } \\
& I T \text { Not needed }
\end{aligned}
$$


20. Below are listed the various states of gectheruel resiurce ? ment. Since you are a lessee of geotheraal lands, you have na-in it through the initial stage of developrent. Flease indicate the stare of developont you've reached on the safortty of your land in each category by placing, a check in the appropriate space.

Type of Geotherwa? Iand Farieral stare Private 0:lies

a. Land held with no aditional development

b. Geological, geophysical, and geocherical testing beins: conducted s. acconolished.

c. Exploratcry drilling usjerway or completed

d. Preparing or completed environnental reports and processin?

e. Production wells bein?, drilled or cospleted

f. Eower plants ui:derway or conpleted

8. Nonelectric uses underway or cospleted

21. How many exploratory wells have you drilled cr all your leases?

$$
\begin{aligned}
& \text { II?-2 } \\
& \text { IT } 3-5 \\
& \text { I } 5 \text { - } 7 \\
& \text { IT } 7 \text { - } 9 \\
& \text { IT } 15 \text { or over }
\end{aligned}
$$


22. Do you think there is a need for ERDA to demonstrate the commercial viability of geothernal energy through selected demonstration prcjects?

$$
\begin{aligned}
& \text { IT critical need } \\
& \text { IT Moderate need } \\
& \text { IT slight need } \\
& \text { IT No need } \\
& \text { II No opinion }
\end{aligned}
$$

We realize that this questionnafre cannot provide finformation in the ispth as that obtained from a personal interview or through narrative responses. Therefore, if you feel that there are issues raised in this questionnalre which need further clarification or if you have any add:tional coments you feel would be of interest to the Congress or any of the items within the questionnalre or related tonics not covered, please feel free to express them. Any further information you can give us will ie sreatly appreciated.

Thank you. 


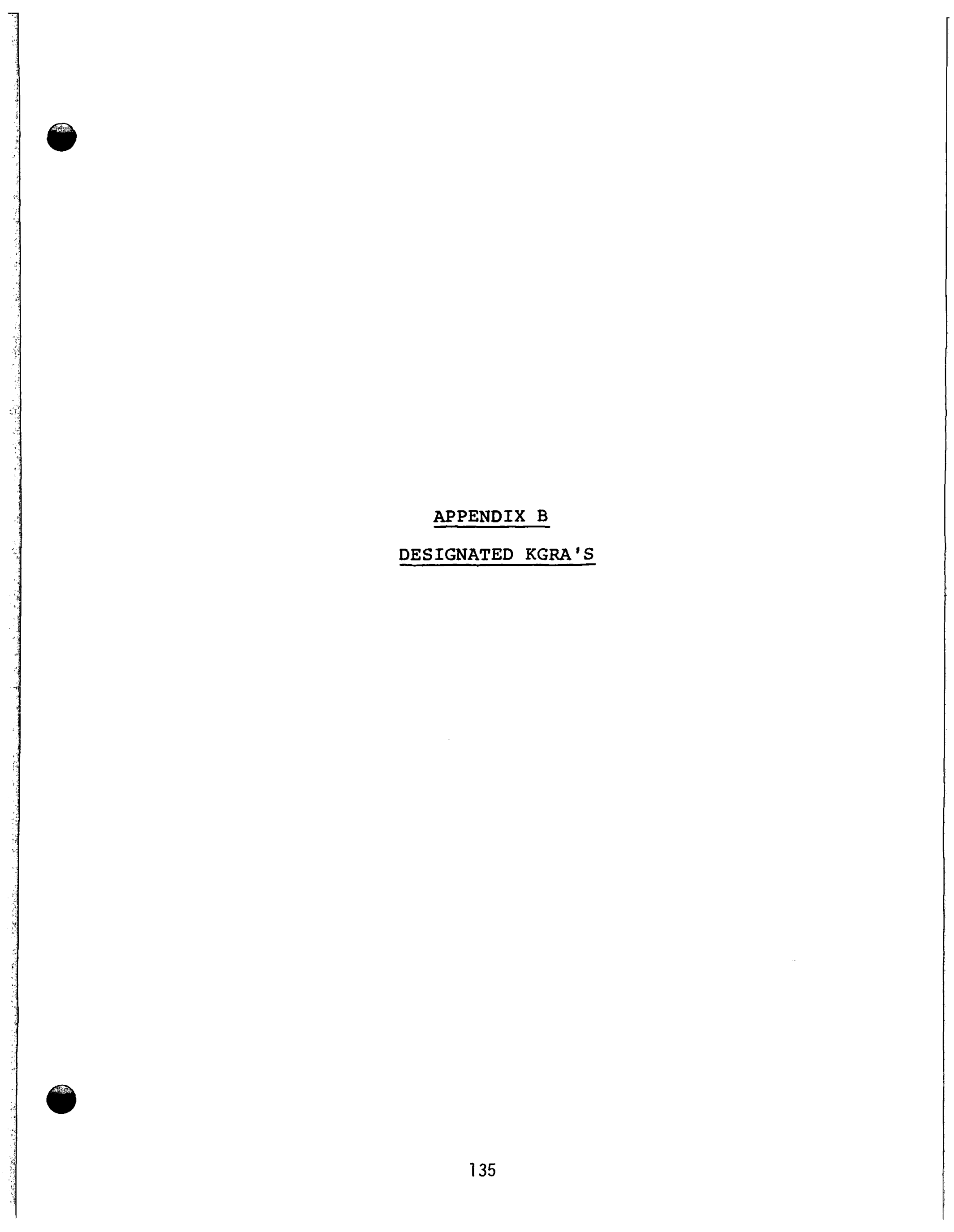


WOWN GEOTYERMAL RESOURCES AREAS (KGRA'S)

AS CLASSIFIED BY THE IIJICATED AREA GEOLOGISTS

WESTERN AND CENTRAI REGIONS

WESTERN REGION

Alaska Area Geologist, Anchorage, Alaska

Alaska

No. of Acres

1.. Geyser Spring Basin

2. Okmok Caldera

20,960

44,800

3. Pilgrim Springs

$\frac{22,400}{88,160}$

Pacific Area Geologist, Menlo Park, California

Arizona

1. Clifton

2. Gillard Hot Springs

$\frac{2,920}{3.700}$

\section{California}

1. Beckwourth Peak

2558

2. Bodie

3. Brawley

4. Coso Hot Springs

5. Dunes

6. East Mesa

7. Ford Dry Lake

8. Gèsers-Calistoga

9. Glamis

10. Glass Mountain

11. Heber

12. Knoxville

13. Lake City-Surprise Valley

14. Lassen

15. Iittle Horse Mountain

16. Love Lady Ridge

17. Mono-Iong Valley

18. Randsburg

19. Saline Valley

20. Salton Sea

21. Sespe Hot Springs

22. Wendel-Amedee

23. Witter Springs

$\begin{array}{r}2558 \\ 640 \\ 28,886 \\ 56,880 \\ 7,680 \\ 38,365 \\ 7,687 \\ 374,910 \\ 25,505 \\ 33,287 \\ 58,568 \\ 14,702 \\ 72,940 \\ 78,642 \\ 1,196 \\ 6,239 \\ 460,256 \\ 12,880 \\ 3,200 \\ 95,824 \\ 7,034 \\ 17,932 \\ 18,152 \\ \hline 1,423,963\end{array}$


Idaho

1. Bruneau

2. Castle Creek

3. Crane Creek

4. Island Park

5. Mountain Home

6. Raft River

7. Vulcan

8. Yellowstone
No. of Acres

5,120

79,722

4,342

28,539

9,520

30,209

3,836

14,164

175,452

Nevada

1. Baltazor

5,617

2. Beowawe

33,224

3. Brady-Hazen

$98,508.22$

640

4. Colado

5. Dixie valley

6. Darrough Hot Springs

$38,347.71$

$8,363.18$

7. Double Hot Springs

29,326

8. Elko Hot Springs

8,960

9. Fly Ranch

10. Fly Ranch Northease

11. Gerlach

12. Gerlach Northease

13. Hot Springs Point

14. Kyle Hot Springs

15. Leach Hot Springs

16. Moana Springs

17. Monte Neva

18. Pinto Hot Springs

19. Ruby Valley

20. Rye Patch

21. Salt Wells Basin

22. San Emidio Desert

23. Silver Peak

24. Soldier Meadow

25. Steamboat Springs

26. Stillwater-Soda Lake

$20,758.66$

7,680

26,326

7,971

8,549

2,561

$12,846.21$

5,120

10,302

8,015

5,743

801

19,232

7,678

5,117

5,966

$8,911.12$

27. Trego

28. Wabuska

29. Warm Springs

30. Wilson Hot Springs

225,260

7,013

11,520

3,812

1,294

$635,462.10$ 
Oregön

130. of Acres

1. Alvord

176,835

2. Belknap-Foley Hot Springs

5,066

3. Breitenbush Hot Springs

13,445

4. Burns Butte

640

5. Carey Hot Springs

7,579

6. Crump Geyser

85,663

7. Klamath Falls

50,300

8. Iakeview

9.. MoCredie Hot Springs

12,165

3,659

8,671

31,284

11. Newberry Crater

22,998

12. Vale Hot Springs

$\frac{13,631}{431,936}$

Washington

1. Kennedy Hot Springs

3,311

2. Mount St. Helens

29,754

3. Indian Heaven

$\frac{2,547}{35,612}$

\section{CENTRAL REGION}

Central Rocky Mountain Area Geologist, Denver, Colorado

Colorado

1. Alamosa County

2. Mineral Hot Springs

3. Poncha

4. Valley view Hot Springs
6.761

5,765

3,200

$\frac{5,099}{20,825}$

utah

1. Cove Fort-Sulphurdale

24,874

2. Crater Springs

3. Lund

4. Monroe-Joseph

5. Navajo Lake.

6. New Castle

7. Roosevelt Hot Springs

8. Thermo Hot Springs
17,321

3,840

16,364

2,522

2,636

29,791

$\frac{26,019}{123,367}$ 
Worthern Rocky Mountain Area Geologist, Casper, Wyoming

Montana

1. Boulder Hot Springs KGRA

No. of Mcres

2. Corwin Springs

$.6,343$

3. Marysville

20.349

4. Yellowst one

19.200

12,763

$\frac{12,763}{58,655}$

Southern Rocky Mountain Area Geologist, Roswell, New Mexico

New Mexico

1. Baca Location No. 1

2. Gila Hot Springs

168,761

3.202

3. Kilbourne Hole

25,134

4. Lightning Dock

23,552

5. Lower Erisco Hot Springs

5.760

6. San Ysidro

7. Socorro Peak

1,915

8. Radium Springs

89.715 .81

$\frac{9,813}{327,852.81}$

GRAND TOTAL

$3,324,984.91$

NOMBER OF KGRA'S

106 


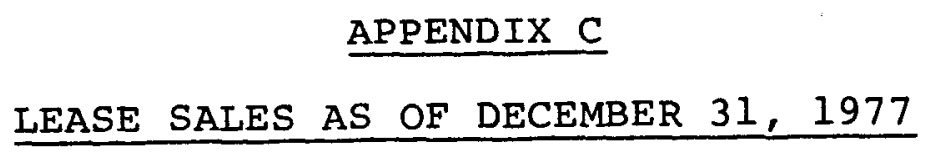




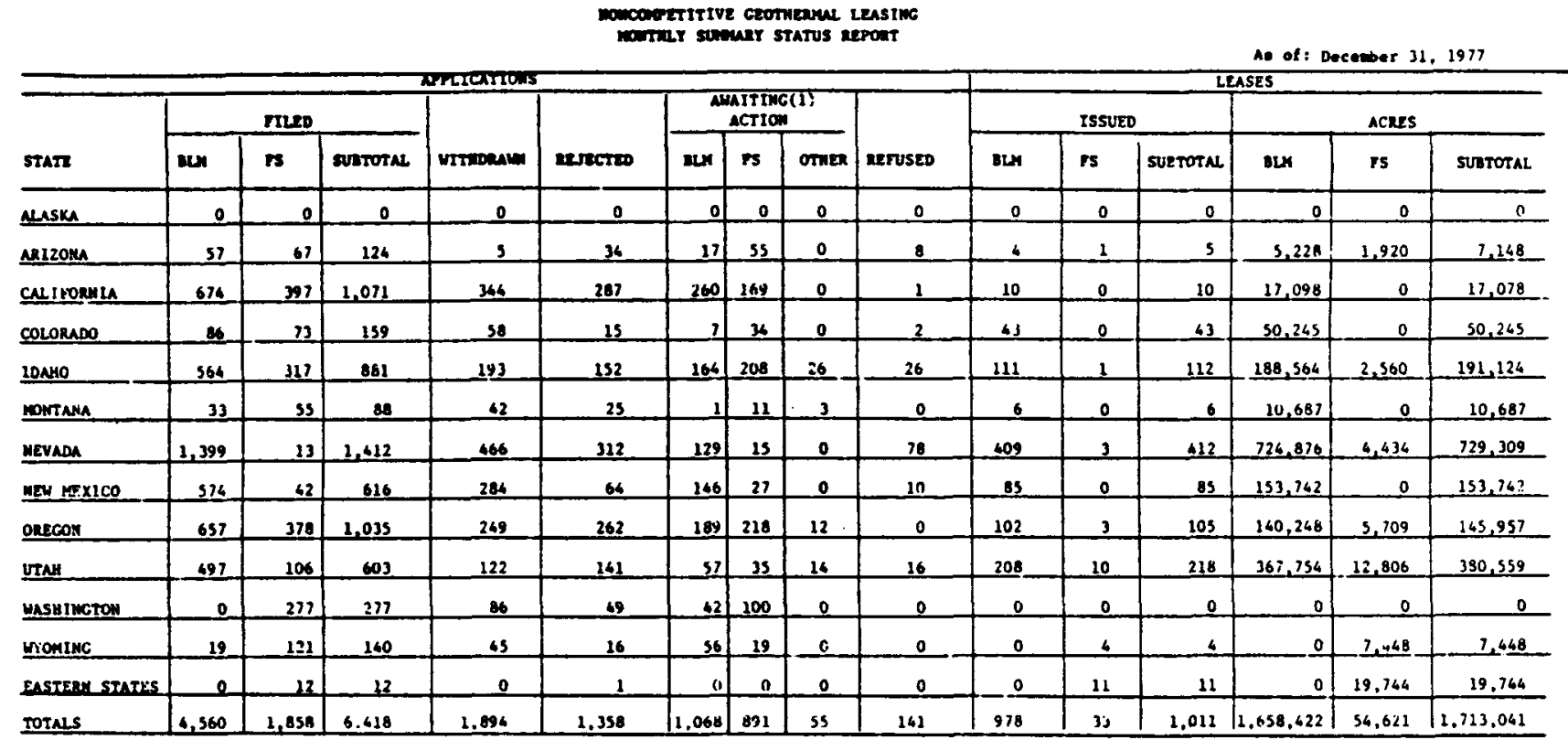

(1) Appllentione maitiog action for the tollowing reacone:

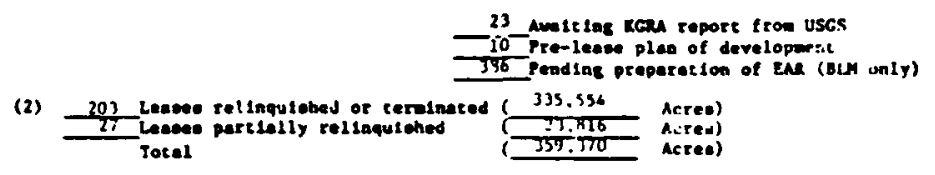

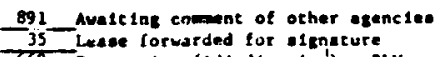

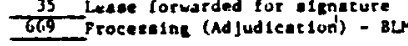
Totel

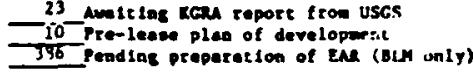




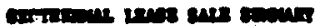

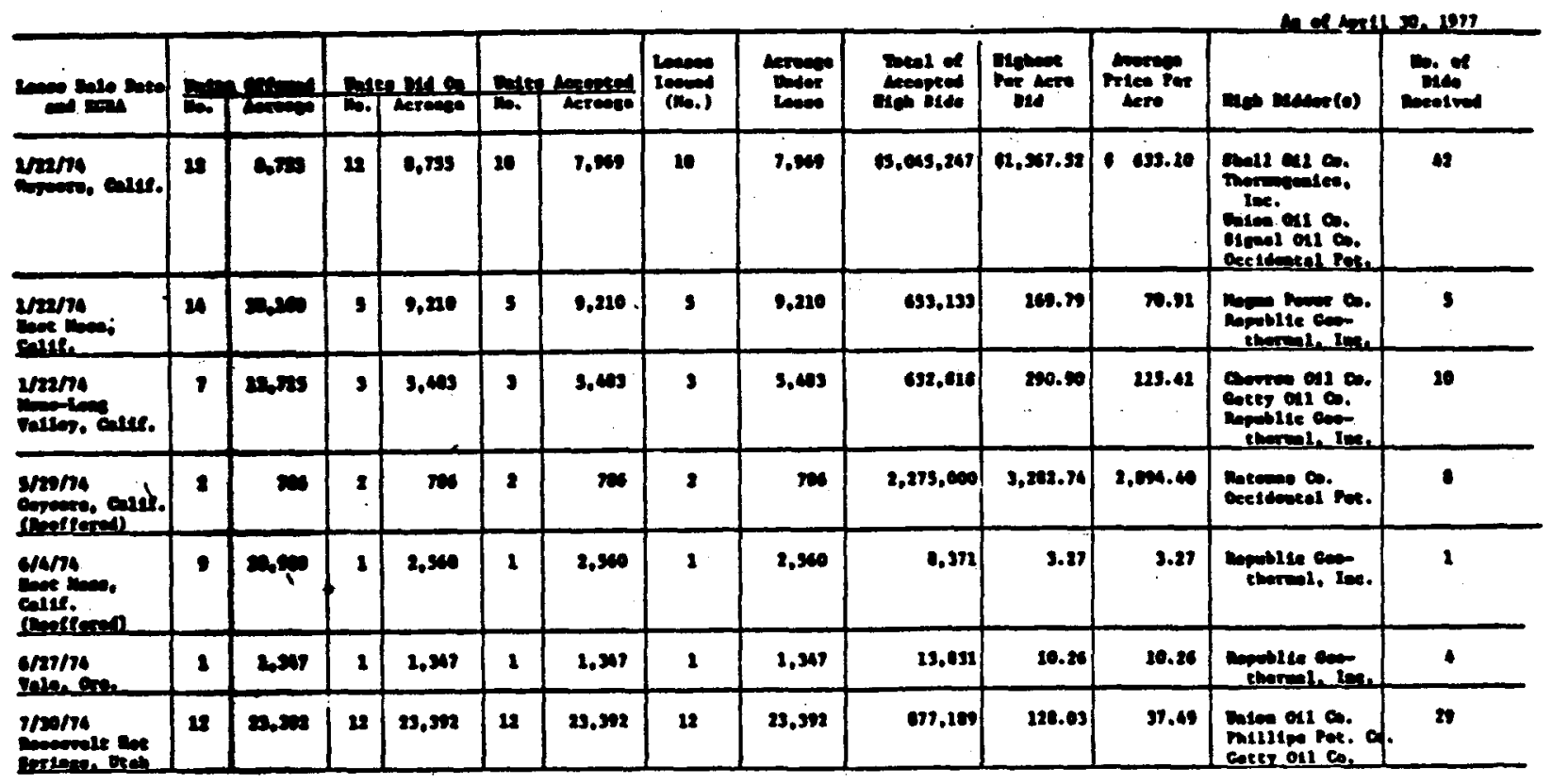

1

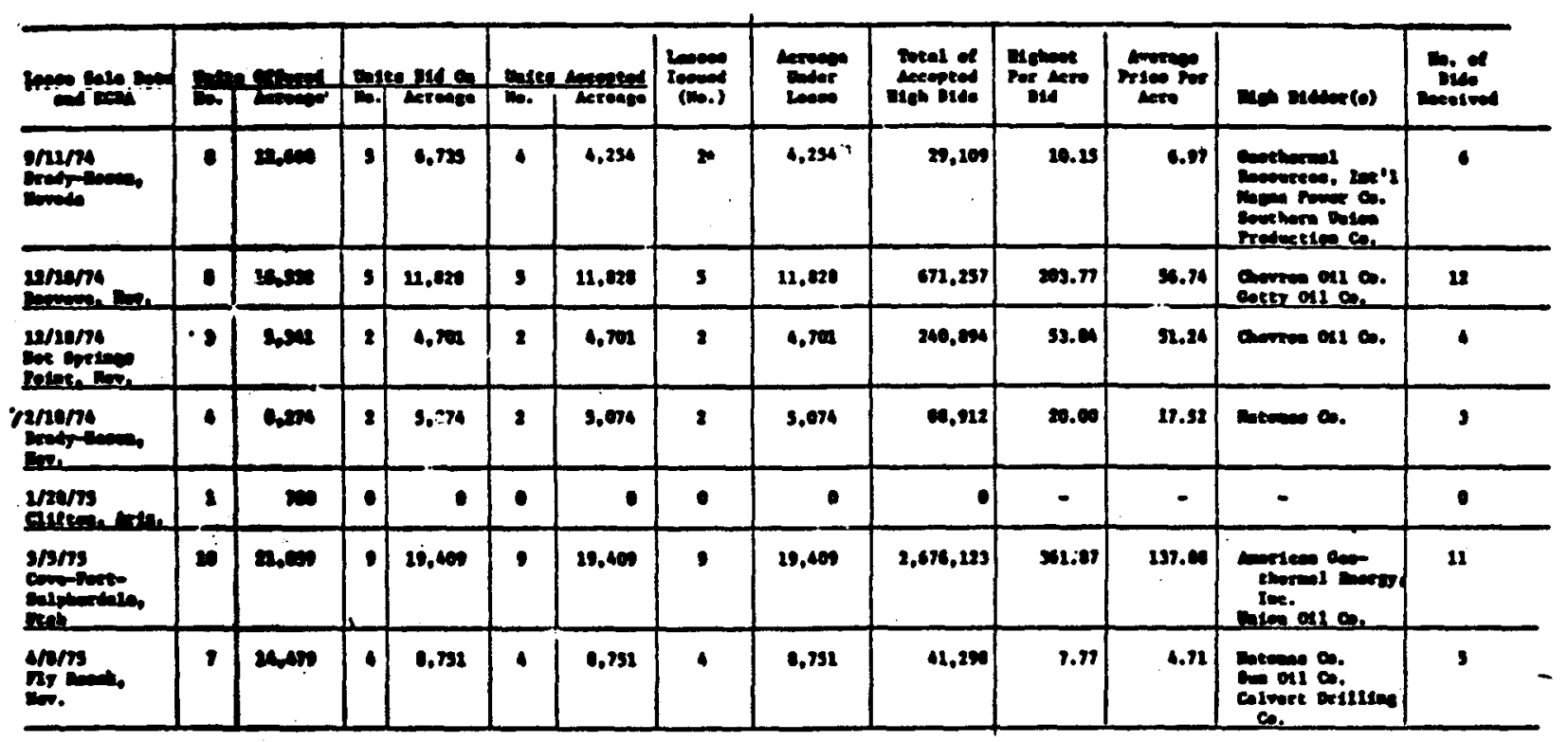

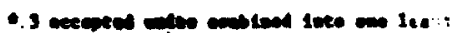




\begin{tabular}{|c|c|c|c|c|c|c|c|c|c|c|c|c|c|}
\hline 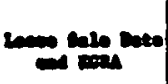 & $\frac{51}{15}$ & $\frac{\text { ceenes }}{\text { teracts }}$ & ts. & $\frac{\cos 6}{\text { terese }}$ & Ext & 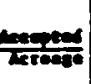 & $\lim _{(10 .)}$ & iner & 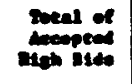 & 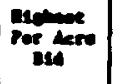 & $\underset{n+e}{n+m}$ & 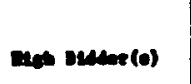 & Desede \\
\hline snsms & $\mathbf{2 2}$ & 24,270 & $\bullet$ & $20,4 n$ & $\bullet$ & $\boldsymbol{u}, \boldsymbol{4 n}$ & $\cdot \bullet$ & $10,4 n$ & - 399,603 & 13.24 & .19 .47 & Federtesen os. & $\mathbf{2 1}$ \\
\hline $3 / 20 / 7 s$ & $\bullet$ & $3,2 n$ & 3 & s.ens & 3 & 3,0 s. & 3 & 9,030 & 13,377 & 3.17 & $2 . \pi$ & Essiev Pet. o. & 3 \\
\hline 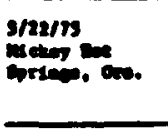 & 24 & 30.34 & 6 & $m, m$ & 3 & 1,800 & 3 & 1,529 & 4,213 & 20.28 & 3.6 & 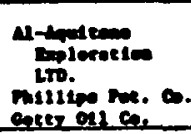 & 1s \\
\hline 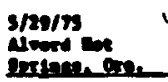 & 24 & 26.030 & $\bullet$ & 22,448 & 6 & 28,048 & - & 12.043 & $\omega, n$ & 17.5 & 7.21 & 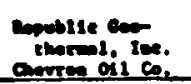 & $\bullet$ \\
\hline tis/rs & 20 & $38 . \mathrm{css}$ & - & 17,00 & $s$ & 11,029 & 3 & 21, 019 & 4,670 & 29.50 & 6.05 & 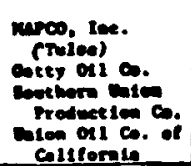 & $\mathbf{x}$ \\
\hline
\end{tabular}

\begin{tabular}{|c|c|c|c|c|c|c|c|c|c|c|c|c|c|}
\hline 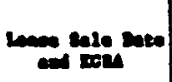 & $\frac{101}{10}$ & $\frac{\text { offeced }}{\text { Aeroese }}$ & Eate & $\frac{140}{x+100}$ & Ent & mented & 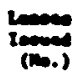 & Heven & 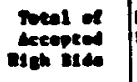 & $\begin{array}{l}\text { Pex } \\
\text { Pex }\end{array}$ & $\underset{\text { Here }}{\text { fries Poe }}$ & Nect numer) & nexpered \\
\hline 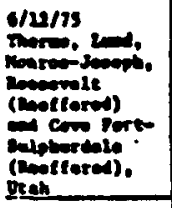 & 16 & $\boldsymbol{s , s e s}$ & 3 & 6,762 & 3 & 6.762 & s & 6,762 & 29.453 & 29.12 & 4.38 & 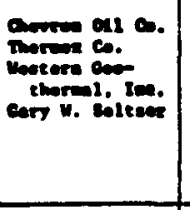 & - \\
\hline Gratrs & $\mathbf{s}$ & 1.616 & 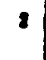 & 8,600 & 2 & 2,6 & 2 & 2,600 & 5,530 & 2.23 & 2.23 & 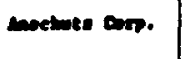 & 8 \\
\hline 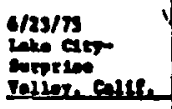 & $x$ & $34,3 x$ & 9 & 16,924 & 3 & 10.594 & s & 20,924 & [34.93] & 22.53 & 22.71 & 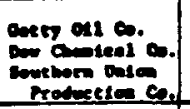 & 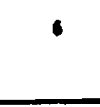 \\
\hline 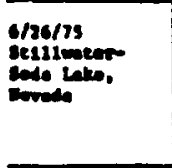 & $\mathbf{n}$ & $47,13 t$ & 6 & 13,299 & - & 13.299 & $\bullet$ & 23.264 & 242.711 & 45.22 & 10.23 & 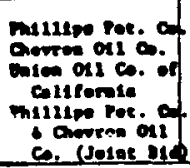 & 1 \\
\hline
\end{tabular}




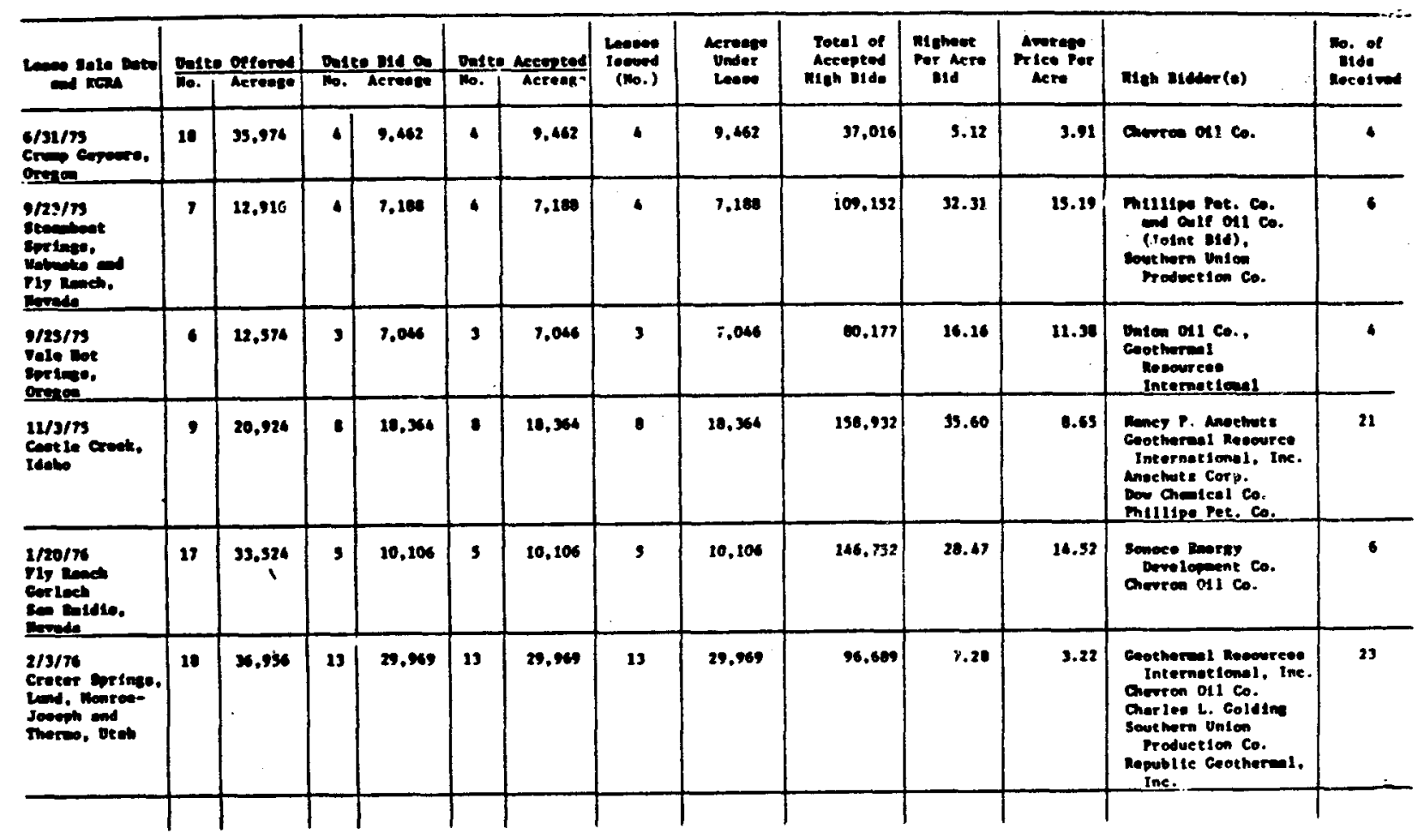

\begin{tabular}{|c|c|c|c|c|c|c|c|c|c|c|c|c|c|}
\hline \multirow{2}{*}{ 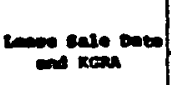 } & \multicolumn{2}{|c|}{ Onte ofform } & \multicolumn{2}{|c|}{ Onste 010 on } & \multicolumn{2}{|c|}{ Oniten nonten } & \multirow{2}{*}{ 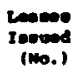 } & \multirow{2}{*}{ 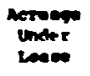 } & \multirow{2}{*}{$\begin{array}{l}\text { Totel of } \\
\text { Accepted } \\
\text { nigh olda }\end{array}$} & \multirow{2}{*}{ 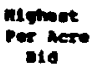 } & \multirow{2}{*}{ 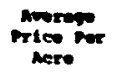 } & \multirow[b]{2}{*}{ mish elecor (n) } & \multirow{2}{*}{ meice } \\
\hline & क. & Acrosp & no. & Acreaso & No. & Acrobege & & & & & & & \\
\hline 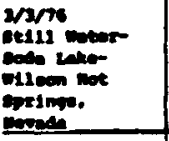 & 26 & 35.192 & 1 & 1,234 & 1 & 1,204 & 1 & $1, \pi 94$ & 4,776 & 3.69 & 3.69 & chercen oll $\infty$. & 1 \\
\hline 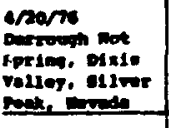 & 29 & 45,642 & $\bullet$ & 17,300 & - & 17,300 & - & 27,300 & 174,312 & 20.6 & 10.05 & 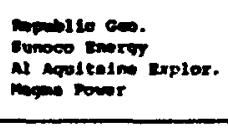 & 11 \\
\hline $\begin{array}{l}\text { sherr } \\
\text { hipheales } \\
\end{array}$ & - & 13.37 & $\bullet$ & 9.023 & 4 & 9.023 & 4 & 9,023 & 41.350 & 0.12 & 4.60 & $\begin{array}{l}\text { minlor.. Ine. } \\
\text { millipe pot. co. } \\
\text { Eren poupe os. }\end{array}$ & 1 \\
\hline 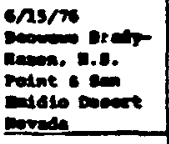 & 27 & $\begin{array}{c}52.000 \\
.1\end{array}$ & 7 & 13.690 & 7 & 13.60 & 7 & 13,690 & 92,345 & 12.91 & 6.73 & 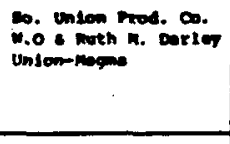 & 7 \\
\hline 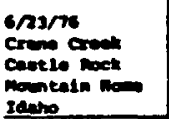 & 3 & 9.003 & 2 & $3.5 \times 1$ & 2 & 3,941 & 1 & 1.301 & 27.006 & 27.20 & 6.05 & $\begin{array}{l}\text { Luere s. Spanpler } \\
\text { so. Union Prod. Co. }\end{array}$ & 2 \\
\hline
\end{tabular}




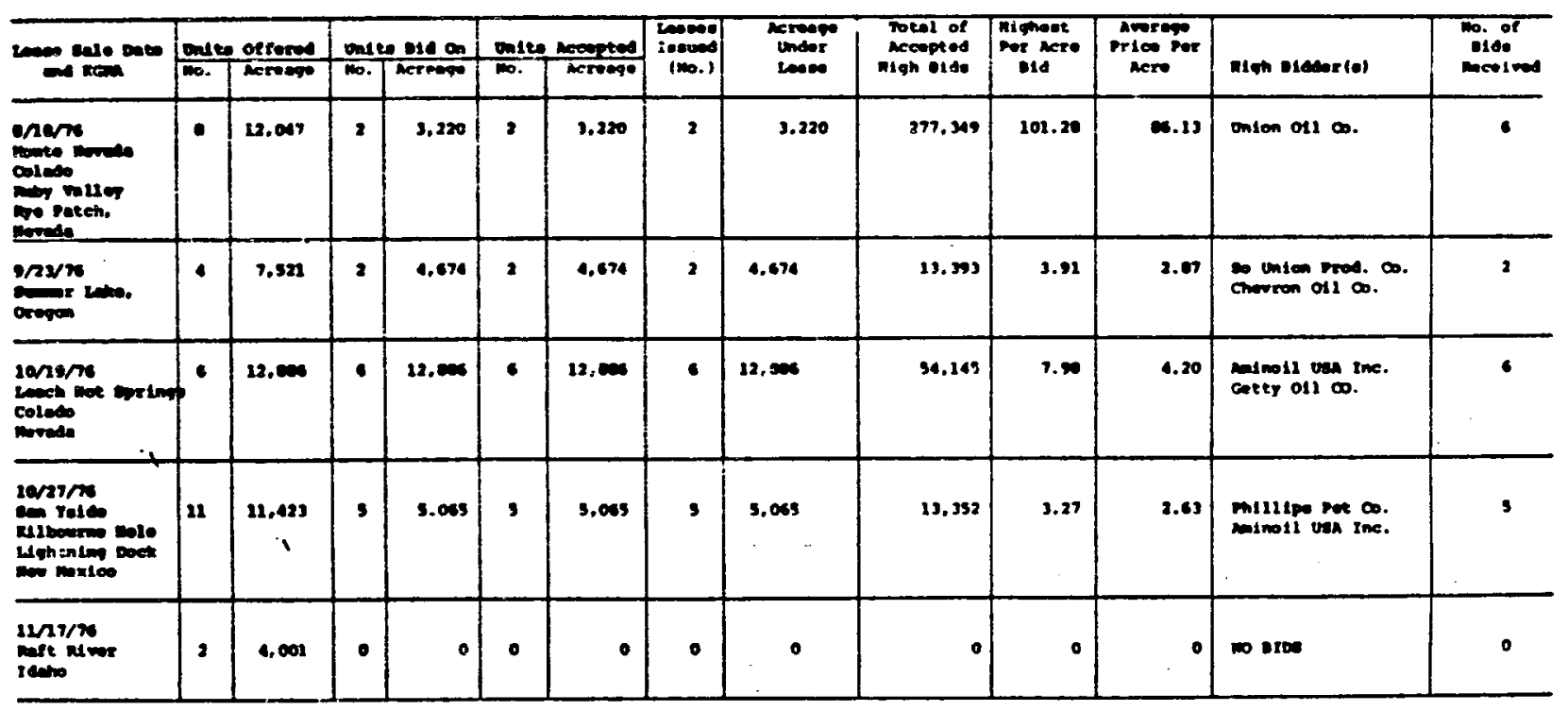

\begin{tabular}{|c|c|c|c|c|c|c|c|c|c|c|c|c|c|}
\hline & & & & & & & & & & & & Ao of Decenbe & er $31, .197$ \\
\hline $\begin{array}{l}\text { Leene Sole Date } \\
\text { anden }\end{array}$ & $\frac{\text { Unice }}{\text { n. }}$ & $\frac{\text { Offered }}{\text { Aereate }}$ & $\frac{\text { Unte }}{x_{0}}$ & $\frac{\text { Ald on }}{\text { Acrenge }}$ & $\frac{\text { Unded }}{\text { No. }}$ & $\frac{\text { Accepted }}{\text { Acrease }}$ & $\begin{array}{l}\text { iecues } \\
\text { Ionued } \\
\text { (No.) }\end{array}$ & $\begin{array}{l}\text { Ac:eage } \\
\text { Under } \\
\text { Lease }\end{array}$ & $\begin{array}{l}\text { To:el of } \\
\text { Accepted } \\
\text { gigh Bide }\end{array}$ & $\begin{array}{l}\text { Higheot } \\
\text { Pet Acre } \\
\text { B1d }\end{array}$ & $\begin{array}{l}\text { Avernge } \\
\text { Price Per } \\
\text { Acre }\end{array}$ & High Itddor (o) & $\begin{array}{l}\text { No. of } \\
\text { Bid } \\
\text { Recelved }\end{array}$ \\
\hline $\begin{array}{l}12 / 16 / 76 \\
\text { Kyle, Nevade }\end{array}$ & 4 & 0.204 & 1 & 2,400 & 1 & 2,400 & 1 & 2,400 & 3.114 & 3.38 & 3.38 & Chevron os1 co. & 1 \\
\hline $\begin{array}{l}\text { 1/18/m, } \\
\text { Boulder, } \\
\text { Moncena }\end{array}$ & 2 & 1,608 & 0 & 0 & 0 & 0 & 0 & 0 & 0 & 0 & 0 & 10 sios & 0 \\
\hline $\begin{array}{l}\text { W/1s/i7 } \\
\text { Alswoos County } \\
\text { Minerel Hot } \\
\text { Springs. Valley } \\
\text { viev, Coloredo }\end{array}$ & 5 & 6.235 & 0 & 0 & 0 & 0 & 0 & 0 & 0 & 0 & 0 & No BIDS & 0 \\
\hline $\begin{array}{l}5 / 17 / 77 \\
\text { Plnto Hot Spen.. } \\
\text { Here 5pes. Nev. }\end{array}$ & 5 & 9.287 & 1 & 1,312 & 1 & 2,312 & 1 & 1,312 & 11,282 & 8.60 & .60 & Getty 011 Co. & 1 \\
\hline $\begin{array}{l}5 / 25 / 77 \\
\text { Bece No. } 1 \\
\text { New Mexico }\end{array}$ & 17 & 29.375 & 11 & 18.050 & 21 & 18.050 & 11 & 18.050 & 574,425 & 133.76 & 31.82 & $\begin{array}{l}\text { Max Exp. tne. } \\
\text { Phillipe Pat. Co. } \\
\text { AnIno11 USA }\end{array}$ & 22 \\
\hline $\begin{array}{l}\text { 6/9/77 } \\
\text { Burns bucte, } \\
\text { Oresen }\end{array}$ & 1 & 640 & 0 & 0 & 0 & 0 & 0 & 0 & 0 & 0 & 0 & No BIDS & 0 \\
\hline $\begin{array}{l}\text { I/19/T) } \\
\text { dolte zar and } \\
\text { Dixie Yalley } \\
\text { RGRA, Nevade }\end{array}$ & 13 & 21,235 & 10 & 14,254 & 10 & 16.234 & 10. & 16.256 & 240,031 & 40.67 & 16.84 & $\begin{array}{l}\text { Earth Power } \\
\text { Republic Geo. } \\
\text { M1llicen O1I }\end{array}$ & 17 \\
\hline $\begin{array}{l}\text { 9/14/77 } \\
\text { Geyoers } \\
\text { Callstoge } \\
\text { xGRA's } \\
\text { Callfornla }\end{array}$ & 3 & 2,937 & 2 & 2,457 & 2 & 2,857 & 2 & 2,957 & 780,451 & 603.00 & 273.28 & Shell $011 \mathrm{co}$.' & 5 \\
\hline
\end{tabular}




\begin{tabular}{|c|c|c|c|c|c|c|c|c|c|c|c|c|c|}
\hline $\begin{array}{l}\text { Lean sole Dace } \\
\text { ond } \mathrm{KCen}\end{array}$ & Inse & $\begin{array}{l}\text { Offered } \\
\text { Acreage }\end{array}$ & Hors. & Acrease & $\begin{array}{l}\text { thece } \\
\text { No. }\end{array}$ & $\begin{array}{l}\text { Acesaced } \\
\text { Acreage }\end{array}$ & $\begin{array}{l}\text { Learien } \\
\text { Issued } \\
\text { (No.) }\end{array}$ & $\begin{array}{l}\text { Acreage } \\
\text { Under } \\
\text { Lease }\end{array}$ & $\begin{array}{l}\text { Total of } \\
\text { Acrepted } \\
\text { H1gh Bide }\end{array}$ & $\begin{array}{l}\text { Higheat } \\
\text { Pro Adre } \\
\text { Bid }\end{array}$ & $\begin{array}{l}\text { Average } \\
\text { Prtce Per } \\
\text { Acre }\end{array}$ & High Bidder (1) & $\begin{array}{l}\text { Mo. of } \\
\text { Mids } \\
\text { Recelved }\end{array}$ \\
\hline 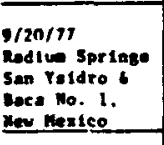 & 12 & 17,960 & s & 11,197 & 8 & 11,197 & : & 11,197 & 233,618 & 37.51 & 20.86 & $\begin{array}{l}\text { Chevron USA. Inc. } \\
\text { Texaco, inc. } \\
\text { Mainoli USA, Ine } \\
\text { Aasex Expl.. Inc. }\end{array}$ & 15 \\
\hline 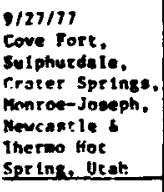 & 9 & 16.300 & 7 & 12.788 & 7 & 12.788 & 6 & $11,13 n$ & 668,826 & 136.35 & 52.30 & $\begin{array}{l}\text { Union } 011 \text { co. } \\
\text { W. H. Hunt } \\
\text { Aminoll USA. Ine. }\end{array}$ & 25 \\
\hline 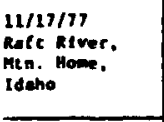 & 11 & 21.020 & 4 & 6,986 & - & 6,986 & 3 & 3,103 & 30,453 & 5.10 & 4.36 & $\begin{array}{l}\text { Union o11 co. of } \\
\text { Calif. } \\
\text { Magm Enerzy, Ind } \\
\text { kaft Rivar Eiec. } \\
\text { Coop. }\end{array}$ & 4 \\
\hline 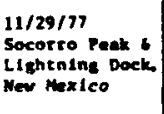 & 19 & 34.654 & 10 & 18,820 & 10 & 18,820 & 0 & 0 & 281,171 & 60.05 & 16.96 & $\begin{array}{l}\text { Hoover H. Wrighe } \\
\text { Aalno11 USA } \\
\text { Sunoco Enerey } \\
\text { Dev. Corp. } \\
\text { Anex Expl. Inc. }\end{array}$ & 18 \\
\hline
\end{tabular}

\begin{tabular}{|c|c|c|c|c|c|c|c|c|c|c|c|c|c|}
\hline $\begin{array}{l}\text { Lease sale dace } \\
\text { end Kofu }\end{array}$ & $\frac{\operatorname{mon} 1 t}{n .1}$ & $\frac{\text { Offered }}{\text { Acrease }}$ & & $\frac{1 \text { te sid on }}{\text { Arreange }}$ & $\frac{\text { Unde }}{\text { No. }}$ & $\frac{\text { Accepted }}{\text { Acteanse }}$ & 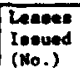 & $\begin{array}{c}\text { Acreesese } \\
\text { Under } \\
\text { Lease }\end{array}$ & $\begin{array}{l}\text { Totol of } \\
\text { Aceepted } \\
\text { Migh Bids }\end{array}$ & $\begin{array}{l}\text { Tisheat } \\
\text { Per Acre } \\
\text { Bid }\end{array}$ & $\begin{array}{l}\text { Avertate } \\
\text { Price Per } \\
\text { nere }\end{array}$ & a1gh Brdener(o) & $\begin{array}{l}\text { No. of } \\
\text { Bide } \\
\text { Recelved }\end{array}$ \\
\hline 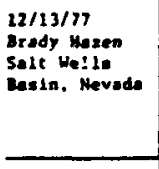 & 22 & 49,316 & , & 14,117 & 7 & 14.117 & 0 & 0 & 200.671 & 32.66 & 14.21 & 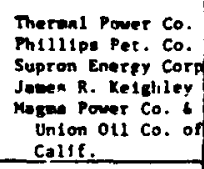 & 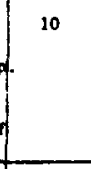 \\
\hline mor.s & s:3 & $1,001,305$ & 248 & 466.257 & 239 & 648.721 & 218 & 412.231 & $18.573,512$ & $n / A$ & 41.39 & $w / A$ & 409 \\
\hline
\end{tabular}




\section{APPENDIX D}

DRILLING IN THE WESTERN UNITED STATES 1975-77 
Summary by States, 1975 Geothermal Drilling, Western U.S.

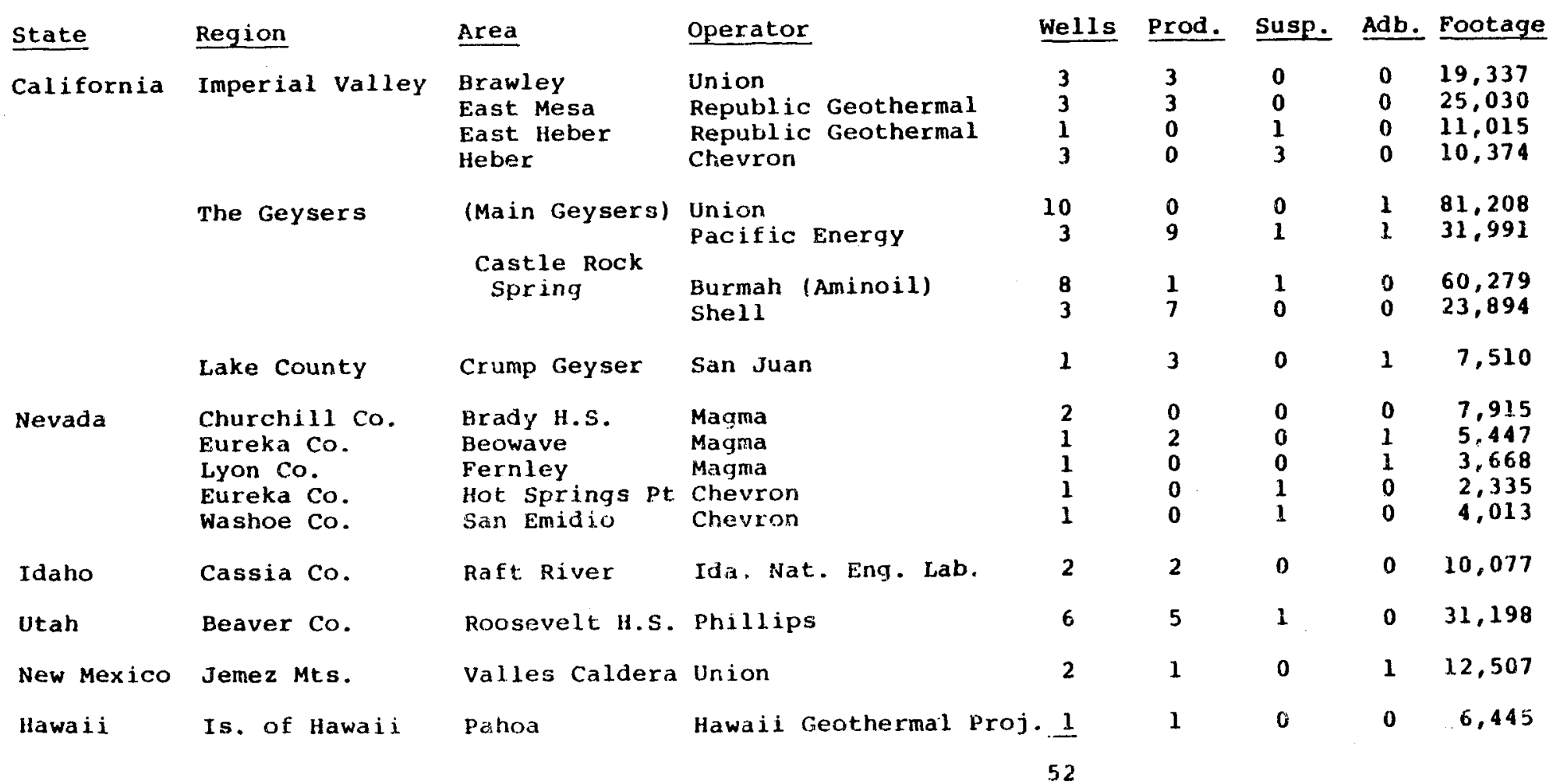

Source: Geothermal Energy Magazine, June 1976. 
Summary by operator, 1975 Geothermal Drilling, western U.S.

\begin{tabular}{|c|c|c|c|c|c|c|}
\hline Operator & $\begin{array}{c}\text { Wells } \\
\text { Drilled } \\
\end{array}$ & Producible & Suspended & Abandoned & Observation & $\begin{array}{l}\text { Total } \\
\text { Footage } \\
\text { Drilled }\end{array}$ \\
\hline Union & 15 & 13 & 0 & 2 & & 113,052 \\
\hline Burmah (Aminoil) & 8 & 7 & 1 & 0 & & 60,279 \\
\hline Republic Geothermal & 4 & 3 & 1 & 0 & & 36,045 \\
\hline Pacific Energy & 3 & 1 & 0 & 2 & & 31,991 \\
\hline Phillips & 6 & 5 & 1 & 0 & & 31,198 \\
\hline Shell & 3 & 3 & 0 & $\mathbf{0}$ & & $23,8.94$ \\
\hline Magma & 4 & 2 & 0 & 2 & & 17,030 \\
\hline Chevron & 5 & 0 & 0 & 0 & 5 & $(16,722)$ \\
\hline Ida Natl. Eng. Lab. & 2 & 2 & 0 & $\mathbf{0}$ & & 10,977 \\
\hline San Juan & 1 & 0 & 0 & 1 & & 7,510 \\
\hline Hawaii Geothermal Pr & j. $\underline{1}$ & $1(?)$ & $\underline{0}$ & $\underline{\mathbf{0}}$ & & 6,445 \\
\hline Totals & 46 & 37 & 2 & 7 & & 338,421 \\
\hline \multicolumn{3}{|l|}{ 1/ Observations holes } & (7) & & & $(355,143)$ \\
\hline
\end{tabular}

Source: Geothermal Energy Magazine, June 1976. 

Summary by Operator, 1976 Geothermal Drilling, Western U.S.

\begin{tabular}{|c|c|c|c|c|c|c|}
\hline Operator & $\begin{array}{c}\text { Wells } \\
\text { Drilled }\end{array}$ & $\begin{array}{l}\text { Produ- } \\
\text { cible } \\
\end{array}$ & $\begin{array}{r}\text { Sus- } \\
\text { pended }\end{array}$ & $\begin{array}{l}\text { Aban- } \\
\text { doned }\end{array}$ & $\begin{array}{l}\text { Obser- } \\
\text { vation }\end{array}$ & $\begin{array}{c}\text { Total } \\
\text { Footage } \\
\text { Drilled }\end{array}$ \\
\hline Union & 25 & 18 & $\mathbf{0}$ & 1 & 6 & 181,524 \\
\hline Aminoil & 6 & 3 & 3 & 0 & $\mathbf{0}$ & 54,491 \\
\hline Republic Geothermal & 7 & 6 & 1 & 0 & 0 & 47,836 \\
\hline McCulloch & 3 & 1 & 1 & 1 & $\mathbf{0}$ & 28,074 \\
\hline Shell & 3 & 1 & 0 & 2 & $\mathbf{0}$ & 24,307 \\
\hline Chevron & 3 & $\mathbf{0}$ & 2 & 0 & 1 & 22,001 \\
\hline Magma & 3 & 2 & 1 & $\mathbf{0}$ & $\mathbf{0}$ & 21,511 \\
\hline Phillips & 3 & 3 & 0 & $\mathbf{0}$ & 0 & 14,855 \\
\hline Thermal Power & 3 & 2 & 0 & 1 & 0 & 13,204 \\
\hline Idaho Nat. Eng. Lab. & 4 & 2 & 0 & $\mathbf{0}$ & 2 & 12,179 \\
\hline Pacific Energy & 1 & 1 & 0 & $\mathbf{0}$ & 0 & 10,550 \\
\hline Amax & 3 & 0 & 0 & 0 & 3 & 5,868 \\
\hline Battelle Pac. NW Lab & 1 & $\underline{0}$ & $\underline{0}$ & $\underline{\mathbf{0}}$ & $\underline{1}$ & 1,352 \\
\hline Total & 65 & 39 & 8 & 5 & 13 & 437.752 \\
\hline
\end{tabular}

Source: Geothermal Energy Magazine, May 1977. 
Summary by states, 1977 Geothemral

Drilling, Western U.S.

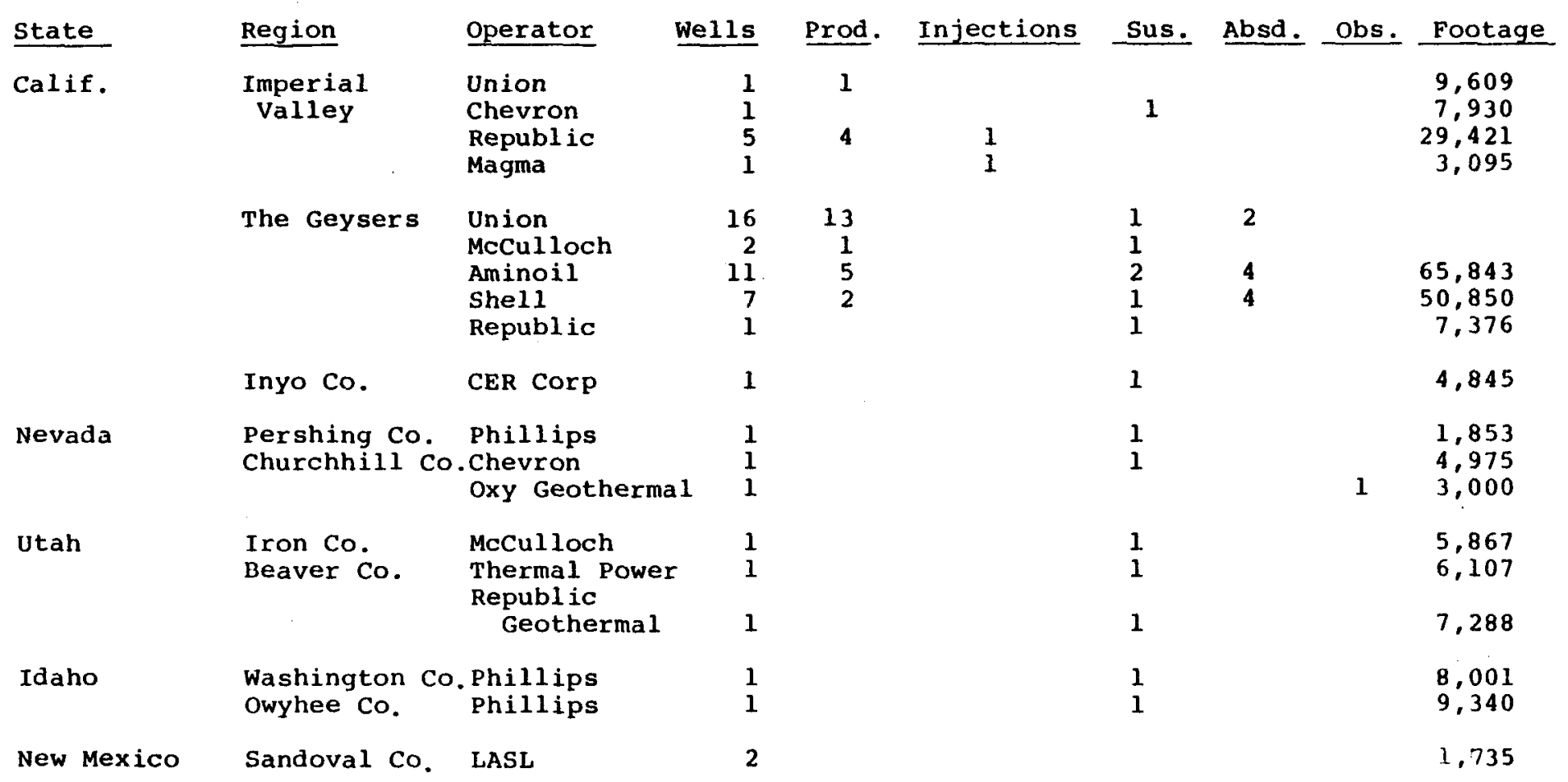

Source: Courtney Isselhardt, Republic Geothermal, Inc., (draft) 1978. 
Summary by Operator, 1977 Geothermal Drilling, Western U.S.

\begin{tabular}{|c|c|c|c|c|c|c|c|}
\hline Operator & $\begin{array}{l}\text { Wells } \\
\text { Drilled }\end{array}$ & Produce & Suspended & Abandoned & Observation & Total Footage & Drilled \\
\hline Union & 18 & 14 & 1 & 3 & 0 & 139,010 & \\
\hline McCulloch & 3 & 1 & 2 & 0 & 0 & 18,880 & \\
\hline Navy (CER Corp) & 1 & 0 & 1 & 0 & 0 & 4.845 & \\
\hline Phillips & 3 & 0 & 3 & 0 & 0 & 19,194 & \\
\hline Chevron & 2 & 0 & 2 & 0 & 0 & 12,905 & \\
\hline OXY Geothermal & 1 & 0 & 0 & 0 & 1 & 3,000 & \\
\hline Thermal & 1 & 0 & 1 & 0 & 0 & 6,107 & \\
\hline Aminoil & 11 & 5 & 2 & 4 & 0 & 65,843 & \\
\hline Shell & 7 & 2 & 1 & 4 & & 50,850 & \\
\hline Republic & 7 & 4 & 2 & 0 & & 44,085 & \\
\hline Magma & 1 & 0 & 0 & 0 & 0 & 3,085 & \\
\hline LASL & (?) 2 & $\ldots$ & 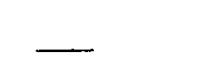 & $\underline{1}$ & - & 1,735 & \\
\hline Totals & 57 & 26 & 15 & 12 & 1 & $(369,549)$ & \\
\hline
\end{tabular}

Source: Courtney Isselhardt, Republic Geothermal, Inc., (draft) 1978 . 
APPENDIX E

FIRMS INVOLVED IN GEOTHERMAL DEVELOPMENT 
Oil Companies: majors and independents

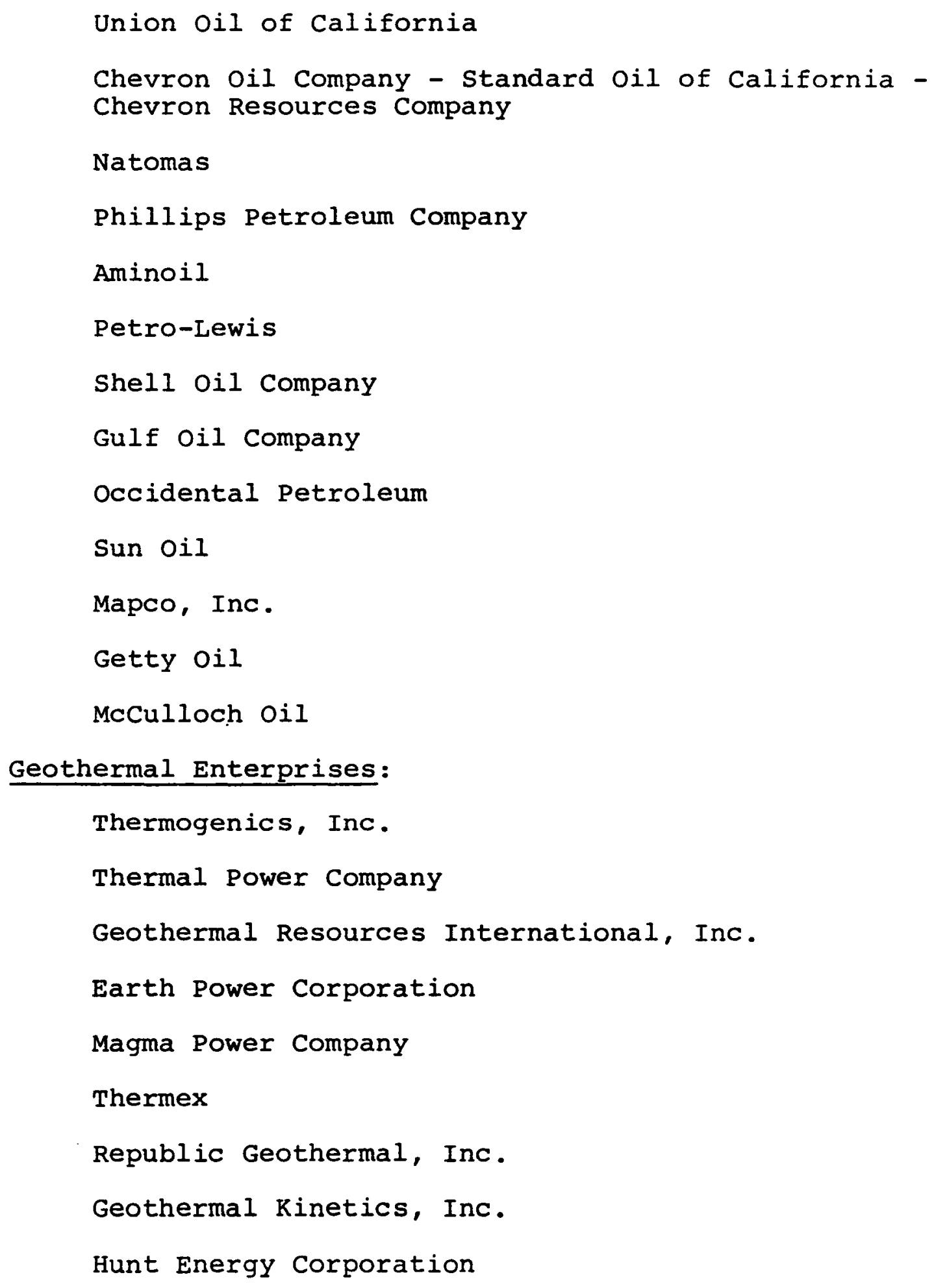


Geothermal Enterprises continued

Thermal Resources, Inc.

Diablo Exploration

California Energy Co., Inc.

Others: Large Integrated Firms

Anadarko Production Co.

Amax Exploration, Inc.

Anschutz Corp.

Dow Chemical Co.

Morton-Norwich Products

Utah International, Inc.

Municipalities:

Burbank

Susanville

Northern California Power Agency

Engineering Firms:

Ben Holt Co.

Bechtel Corporation

Morrison-Knudsen

Rogers Engineering

VTN Consolidated

Utilities

Pacific Gas and Electric, San Francisco, California.

Pacific Power and Light, Portland, Oregon.

Sierra Pacific, Reno, Nevada. 
Utah Power and Light

San Diego Gas and Electric, San Diego, California.

Public Service of New Mexico, Albuquerque, New Mexico.

Southern California Edison, Rosemead, California.

California State Department of Water Resources, Sacremento, California.

Imperial Irrigation District, Imperial, California.

Arizona Public Service, Phoenix, Arizona. 


\section{APPENDIX F \\ ERDA BUDGET FOR FY 76-78}




\section{ENERGY RFSEARCII AND DEVEL.OPMENT ADMINISTRATION}

\section{FY 1978 BUDGET REQUEST}

\begin{tabular}{lllll}
\multicolumn{4}{c}{ BUDGET AUTHORITY (IN MILLIONS) } \\
\hline \multirow{2}{*}{1976} & 1977 & January & February & Apr11 \\
\hline
\end{tabular}

I. Energy Research, Development \& Demonstration

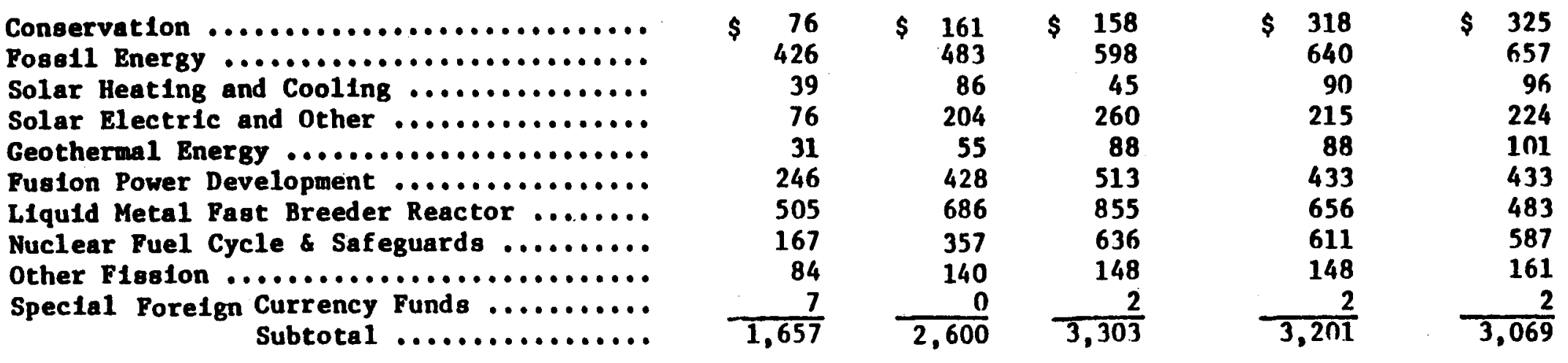

II. Supporting Research

Environmental and Blomedical Research .... Basic Energy Sciences

Subtotal .............

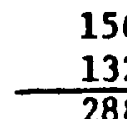

156

288

$\begin{array}{r}210 \\ 175 \\ \hline 385\end{array}$

$\begin{array}{r}215 \\ 175 \\ \hline 390\end{array}$

III. FInanctal Incentive Act Ivttles

Geothermal Resources Development Fund .... A1ternative Fuels Demonstration Program .. Subtotal...............
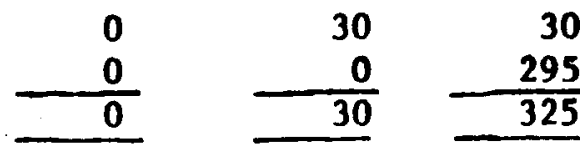

$\begin{array}{r}30 \\ 300 \\ \hline 330 \\ \hline\end{array}$

30

330

Total Energy Research, Devel. Demo. Prog.

$\underline{\$ 1,945}$

$\$ 2,975 \quad \$ 4,013$

$\$ 3,921$

юே

Source: Budgetary Implications of the President's Energy Policy, April 20, 1977, Overview and Perspective. 


\section{APPENDIX G \\ GEOTHERMAL ENERGY RESEARCH, DEVELOPMENT, \\ AND DEMONSTRATION ACT OF 1974 (P.L. 93-410)}


Public Law 93-410

93 rd Congress, H. R. 14920

September 3, 1974

\section{An Act}

To further the conduct of resenrch, development. and demointrutions in geotiermal energy technologies, to extablish a Geothermal bnerky Courdi. untion and Innagement l'roject, to jrovide for the carrying ont of reaserch and develojument in centhermul energy tochnolngx, to cirry out a program of demonstrations in technologics for the utilization of geothermal resonrces. to establigh a Ionn guarants program for the financing of geothermal energx derelopment, and for ot her purposes.

Be it enasted by the Senatc and House of Representatives of the Uniled States of Amcrica in Congress ussembled.

silorr TITL:

Section 1. This Act may be cited as the "Geothermal Fuergy Resenrch, Development, and I)emonst ration Act of 1974".

\section{madivos}

Src. 2. The Congress hereby finds that-

(1) the Nition is currently suffering n critical shortnge of environment ally acceptable forms of energy;

(2) the inalequate organizational structures and levels of funding for encrgy researdi hive limited the Xation's current and future options for mreting energy seeds;

(3) electric energy is a clemin and convenient form of energy at the location of its use and is the only practicable form of energy in some modern applimations, lut the demand for electric energy in every region of the ["nitel states is taxing all of the alternative energy snuress presently available and is projected to increase: some of the sources available for clectric power gencration are already in short supply, and the development and use of other sources presently involie undesirable environmental impacts:

(4) the Aition's critical energy problems cun be solved only if a national commitment is made to dediente the necessary financial resources, and enlist the cooperation of the private and public sectors, in developing geothurmal resources and other nonconventional sunce's of energy:

(5) the conventional geothermal resources which are presently being used have limited tolal potential : but geothermal resoureces which are different from those presently heing used, and which have extreinely large energy. content, are known to cxist;

(6) some genthrimal resources contain energy in forms other than heat; examples are methone and extremely high pressures available mon release as kinet ic energy;

(7) some geothermal reseureses contitin valuable byproducts such as potahle water and mincral compounds which should bo processect and recovered as national resourres:

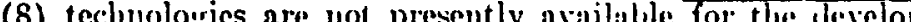

inent of mosit of these areothermal resonrers, but trechmologies for the generation of electric cnergy from grothermal resources are potentially ecoromical and enviromentally desirable, and the development of geothermal resourees otfers possibilities of process energy and other nonclect ric: applications;

(9) much of the known genthermal resoures exist on the public lands;

\author{
Geothe mal \\ Energy Research, \\ Development, \\ and Demonstra- \\ tion Act or \\ 2974. \\ 30 USC 1101 \\ note.
}

30 USC 1101. 
Pub. Law 93-410 - 2- September 3,1974

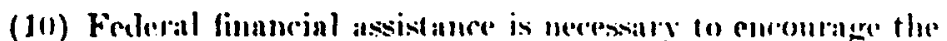
extensive explomation, research. and derelopmint in greothermal resomeres which will bring these trehomolngies to the point of amimerrial application:

(11) the advancement of techunligy with the comperation of privale industry for the production if useful forms of energy from geothermal resources is important with respect to the fied. eral responsibility for the general welfare. to facilitate commeres. to encourage productive harmony bet werll man and his environment, and to protect the public interest : and

(12) the Fedeml Goremment should incourage and assist privute indust ry through Federal assistance for the development and denuonstration of practicable means to produce useful enerey from geothermal resources with environmentally acceptable processes.

DEFINITIONX

30 USC 1102. Src. 3. For the purposes of this Act-

(1) the term "geothernal iesources" mouns (A) all products of geothermal precesses. embracing indigrnous steam, hot water, and brines, (B) steam and other gasc's, hot water and hot brines. resulting from water, gas, or other fluids artificially introduced into geothermal formations. and (C) any byproduct derived fro: " them;

(2) the term "byproduct" menns any mineral or minerals which are foumd in solution or in association with geothermal resources and which have a value of less than 75 percent of the value of the genthermal steam and associated genthermul resources or are not, because of quantity. quality, or technical diffuculties in extraction and production. of sufficient value to varrant extraction and production by themselies:

(3) "pilot plant" means an experimntal unit of small size used for early evaluation and devclopment of new or improved processes and to obtain technical. enginecring, and cost data;

(t) "demonst ration plant" menus : a complete facility which produces electricity. heat energy or use ful byproducts foi conmercial disposal from geothermal resouress and which will make a sienificant contribution to thr knowledge of full-size techuolngy, plant operation. and process economics:

(5) the term "Project" means tho (ieothermal binergy Conrdi:" nation and Management Project establislied by section i01 (a) :

(6) the teruu "fuml" means the (ieothermat liesources Inevelop)mont Fund established by section $2(4)(n)$ : and

(i) the term "(hatimun" means the ('hairman of the Project.

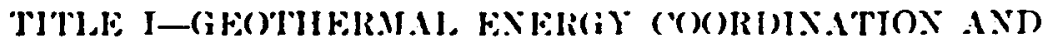

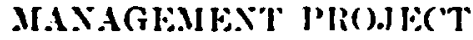

\section{FST.IBL.ISIIMIF:AT}

30 usc 1121. Sire. 101. (a) There is hereby establishod the (reothermal Energy conrdination and Mauarement Project.

Nembersh1p. a) ris. 1000 (b) (1) Tlir Project shall lo composed of six menhleers as follows: (A) one "lpmesinterl by the P'msident :

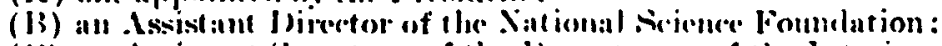

(C) an Assistant Sereretary of the leeprertment of the laterior:

(I) "n Assoriate Administrator of the Nitional Aernonuti and Space Adnuinistmition: 
September 3, $1974 \quad-3-\quad$ Pub. Law 93-410 and

(E) the Gencral Matnager of the Alomie binery ('ommission;

(F) an Issistant Administrutor of the Federal Energy Administration.

(2) The President shall designate one member of the Project to serve as ('hairman of the l'roject.

(3) If the individual appointer under patragraph $(1)(A)$ is an officer or employere of the lederal (iovernment. he shatl rerecive no additional pay on account of his service as it memlxor of the project. If such indivilual is not an oflicer or cmplovere of the Federal (ioversment, he shall be entitled to recejor the daily mpuivalent of the anmual rate of hasic pay in elfect for level 15 of the Exerntive sidhedule (5 U.S.C. 5315) for "ach day (including tratrelt ime) during which he is engaged in the acethil performance of luties vested in the l'oject.

(c) The Project shall have orerall responsilility for the provision of offective nallagement and coordination with respect to a national gcothermal encrgy research, development, and demonstration program. Such progriam shall include-

(1) the determination and evaluation of the resource base;

(2) research and development with respect to exploration, extraction, and utilizat jon techmologies;

(3) the demonstration of appropriate teclunologies; and

(4) the Joan guaranty program under title 11 .

(d)(1) The Project shall carry out its responsibilities under this section acting through the following Federal atgencies:

(A) the Department of the Interior. the responsibilities of which shall include evaluation und assessment of the resource base, including development of exploration technologies;

(B) the National Aeronauties and Space Administration, the responsibilities of which shall include the provision of cunt ract manngement capability, craluation and assessment of the resource base and the decelopment of technologies pursuant to section 102 (b) ;

(c) the Atomic Fnergy Commission, the responsibilities of which slmall include the development of technologies: and

(D) the Sational Science Foumdation, the responsibilities of which shall include basic and applied insearch.

(2) Upon request of the Project, the hiead of any such agency is authorized to detail or assign. on a reimbursable basis or otherwise, nny of the personnel of sucl ayeney to the Project to assist it in carrying out jts responsibilities under this Act.

(e) The Project shall have explusive anthority with respenct to the establishment or approval of prourrams or projects initiat ed under

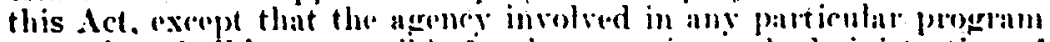
or projert shatl be responsible for the operation and administ ration of such program or project.

\section{PREMHA HFFIXITIIX}

Ste: 102. (a) (1) The Chairman. acting throush the Administ rator of the Nat ional Leronatities and Spare . Alministmation. is nuthorized and directed to prepare a comprehensive prongram detint ion of an integrated effort and commitment for effertively doveloping greothermal

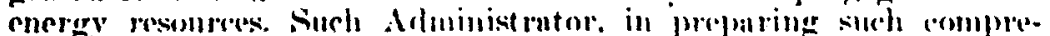
hensive program definition, is anthorized to comsinlt with other fordoral agencies and non-Federal intities. 
88 STAT. 1082

Transmittal to President and Coniress. Interim reports.

Inventory schedule and objectives, transmittal to President and Congress.

Pub. Law 93-410

$-4-$

September 3, 1974

(2) Whe (hairman slaall tiansmit such comprehonsive prorram definition to the l'resident and to ancl, Ilouse of the Congress. Interim reports sluall le transmitted not later than Novemier 30, 19it, and not later than .Jammary 31, 1975. Such comprelrensive program definition shall le transmitted as sonn as possible therenfter, but in any case not later than A ugust 31. 197\%.

(3) As part of the comprehensive program definition required by paragruph (1), the Chairman, acting through the Feological survey. shall transmit to the l'resident and to each Jlouse of the Congress a schedule and oljectives for the inventorying of geothermal resources.

(b) The National Arronanties and Space Administration is anthorized to undertake and enrry out those programs assigned to it by the Project.

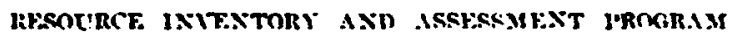

30 USC 1123.

Six. 103. (a) The Chairman shall initiate a resource inventory and ussessment pirgeram with the objective of making regional and untional appraisals of all types of geothermal resources. including iclentifiention of promising target a reas for indust rial exploration and clevelopment. The specific goals sluall include-

(1) the improwement of geophysical, freohemical, geological, und hydrologrcal techniques necessiry for locating and evaluatin': grothermal risonrces;

(2) the development of better nothods for predicting the pow potential and longerity of geothermal reserioirs;

(3) the determination and assessment of the nature and power potential of the decper unexplored parts of high temperature geothermal convection sistems; and

(4) the surver and assessment of regrional and national geothermal resources of all types.

(b) The Chaimun, acting through the Geological Survey and other "punoprinte nurencirs. shall-

(1) derelop and carry out a general plan for the orderly inrentorying of all forms of geothermal resources of the Federal lands and, where consistent with property riglits and determined by the Chairman to be in the national interest, of non-Federal lunds;

(2) condurt regrional survers, based upon such a general plan. using innovative geological, geophysical, geochemical. and st rata. arraphic drilling technigues. which will lead to a national inven cory of geothermal resources in the Cinited States;

(3) publish and make availalile maps, reports, and other locuments developel from such survers to encouragre and facilitate the commercial development of gerithemmal resoures for beneficinl use and consistent. with the nat ional int crest;

(4) make such recommendations for legislation as may from time to time appenr to be necessary to make Fecheral leasing policy for geothermal resources consistent with known inventories of various resource types, with the current state of technologies for geothermal enerer development, aud with current evaluations of the environmental impacts of such development; and

(5) participate with, approprinte Foderal agencies and nonFederal entities in research to develop, innprove, und test technolngies for the discovery and evaluation of all forms of geothermal resources, and conduct rescarch into the principles cont rolling the location, occurrence, size, tenperature. (nergy content, producibility, and exonomic lifetimes of geothermil reservoirs. 


\section{September 3,1974 - 5 - Pub. Law 93-410 \\ RESEARCH AND WFEMATMENT

Src. 104. (a) The (hairman. acting through the uppropriate Ferl- 30 usc 1124. eral agencies and in comperation with nom-Federal entities, shall initiate a research aud develnpment program for the purpose of resolving all major fochnieal problems inlithiting the fullest possible conmmeteial utilization of geothermal resources in the United Sitates. The specific poals of such programs shall inelude-

(1) the development of effective and efficient drilling methorls to operute at high temperatures in formations of geothermal interest :

(2) the development of reliable predictive methods and control techniques for the production of geotlicrmal resources from reservoirs;

(3) the exploitation of new concopts for fracturing rock to permit recovery of contained hent reserves:

(t) the improrement of equipment and techmology for the extraction of genthermal resources from reservoirs:

(5) the development of improved methods for converting geothemal resources and byproducts to useful forms:

(6) the levelopment of improved methods for cont rolling emissions and wastes from greothermal utilization facilities. including new monitoring methods to any extent neressary:

(7) the development and evaluation of iraste disposal control techmologies and the eraluation of surface and subsurtace envirommental effocts of geothermal derelopment :

(8) the improvensent of the techuical capability to predict environnental impacts resulting from the de velopment of geothermal resoures, the prejumation of envirummental impact statements. and the assuring of compliance with applicalle stindards and criteria ;

(9) the identification of social, legal, and economic problems associated with geothermal development (boih local!y and regionally) for the purpose of (ieveloping policy and providing a framework of policy alternatives for the commercial wtilization of geothermal resonrces;

(10) the provision for an adequate supply of scientists to perform required geothermal research and development activities; and

(11) the establishment of a propram to enrominge States to establish and maintain greothermal resources clearinghouses, which shall serve to $(\boldsymbol{A})$ provide grothermal resonrees dovelopers with information with respect to applicallo local. State, and Federal laws, rules. and regulations. (13) coordinate the proressing of permit applications, impact statements, and othey information which groothermal resoneres developers are required to provide. (C) encoumage nuformity with respect to local and State laws, rules, and reculations with resiect to geothermal resources developmicut, and (I) encourage establishment of land use plans. which would incluche zoning for greothermal resomrees develop. ment and which would assure that geothermal resources devel. opers will be able to carry out development programs to the production stange.

(b) The (haiman, artinge through the appropriate fedemal agen-

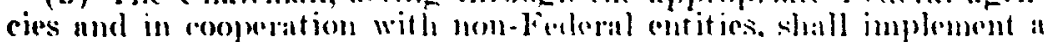
cosolinated program of researeh and derelopment in moley to demonrafe the terhnieal means for the axtaction and utilization of the source buse, including any byproducts of such base, and in order to 
accomplish the anols istublished by subsection (a). Research authorized by this Act laving potential applientions in matters other than geothermal energy muy lie pursued to the cxtent that the findines of such rescarch can be published in a form for utilization by others.

\section{Drasonstratiux}

x USC 1125 .

Sirc: 105. (a) The Chairman. acting through the appropriate Federal agencies and in conperation with non-Frderal entitis. shall initinte a program to design and construct gentliemal denoustration plnnts. 'The sperific goils of such prosram shall include-

(1) the development of enonomical geothermal insources production systems and components which nect enitionuental standards;

(2) the desion of plants to produce electric power and, where uppropriate. the large-scale production and utilization of any use. ful byprodurts;

(3) the involvement of engincers. analysts, technicinns, an managers from industry field and powerplant developunent, which shall fend to the early industrial exploitation of adranced gen: thermal resources:

(4) the provision for an adequate supply of trained geotherma! engincers and rechnicians;

(i) the provision of experimental test beds for enmponent tes ing an evaluation by labolatories nperated by the IFederal Govermment, industry, oi inst it utions of higher edication:

(6) the const riction and operation of pilot plants: and

(7) the construction and operation of demonstration plants.

(b) In carrying nut his responsibilities und re this section. the Chair. man. ncting thmugh the appropriate lederal atencies. and in conperation with non-Federal cutities. may provide for the establishment of onc or more demonstration projects utilizing each gonfinemal resourer hase involved, which shall inchude. as appropriate. all of the (xp)lorntion. siting. drillingr. pilot plant comstrurtion and operation. demonstration plant construction and operation. and oflucr facilities and activities wluirh nay he necessary for the generation of elcetric cnerge and the utilization of geothernial resource mproducts.

(c) The Chaimm, acting through the apnropriate Federal agen-

Coope rat Ive agreerients. cies, is authorized to investigate and enter into agreements for tho cooperative development of ficilities in domonstrate the production e? eneray from genthermal resources. 'The responsible Federal agenry may considict-

(1) conperative agrecments with utilitins and non-Federal govermmental entitirs for ennst ruction of facilitics to produce encrey. for comonereisl disposition : and

(2) conperutite agreenents with nther Federal ngencies for the consturtion and operation of facilitios to produce energy for direct Federal consumption.

(d) The irsponsihl. Fecleral agnney is authorized to investigate the fensibility of, consiruct, nnd operate. deminust ration projerets irithout entering juto conperation nemerments with respect to such projects. if the Clonirmme finds thint-

(1) the nuture of the resnurer. the gengraphical Inention. the sente and enginerering design of the facilities. the terinnienues of pmduction. or any oflier signifient factor nf the proposal offers opportunities to muke important contributions to the gener:! 
September 3,1974 - 7- Pub. Law 93-410 88 STA'?. 10 S

knowledge of geothemmal resources, the techuiques of its development, or public confidenco in tho technology ; nnd

(2) there is no opportunity for cooperative ugreements with any utility or non-Federal rovemmental entity willing and able to comperate in the demonstration project under subsection (c) (1), and there is no opportunity for cooperative agrements with other Federal agcncies under subsection (c) (2).

(e) Before favorahly considering proposals under subsection (c). the responsible Federni nerncy must fund that -

(1) the nature of the resource. the gengraphical location. the senle and engineering design of the facilities. the techniques of production, or any other signifient factor of the proposal oflers opportunities to make importint contributions to the genernl knowledge of genthermal resources, the techniques of its develop. ment, or public contidence in the technology;

(2) the developnent of the practical benefits as set forth in paragraph (1) are unlikely to be acconiplished without such cooperative development : and

(3) Where non-Feleral participants are involved, the proposal is not eligible for adegute Federal assistance under the loan guaranty provisions of tit le 11 of this Act.

(f) If the estimate of the Federal investment with respect to contruction and operation costs of any demonstration project proposed o be established under this section exceeds $\div 10,000,000$, no anount may be appropriated for such project except as specifically authorized by legislation herenfter enacted by the Congress.

$(g)$ (1) At the conclusion of the prosram under this section or us scon thercafter as may be practicable, the responsible Federal agencies shall, by sale, lense, or otherwise. dispose of all Federal property interests which they have acyuirol pursuant to this section (including mineral rights) in accordance with existing lat and the terms of the cooperntive agreements involved.

(2) The agency involved shall, under appropriate agrecuments or Projec: kyother arrangements, provide for the disposition of geothermal resource products, disbyproducts of the project administered by such agency.

Federai sroFerty interests, disposal.

SCIEXTJUT AND THCHNICAL EDECATION

Sec. 106. (n) It is the policy of the Congress to encourage the 30 isc 1126. development and maintenance of programs throngh which there may be provided the necessary trained personnel to perform required geothermal research, development, and demonstration activities under sections 10:3, 101, and 105.

(b) The Sational Science Foundation is authorized to support programs of edmention in the sciences and enginecring to carry out the policy of subsection (a). Such support may include fellowships, traineships, lechmical training programs, techuologist training pra. grams, nnd smmmrer inst it ute programs.

(c) The Tational Sciemer Fommlation is anthorized and directed to coordinute its actious: to the naximum extent procticable. with the Projert or any permanent fonleral orianization or agency having jurisdiction over the energy research and development functions of the Unital States, in lefermining the optimal seleretion of prograns of educution to carry out the policy of subsection $(n)$. 
88 STAT. 2086

Pub. Law 93-410

$-8-$

September 3, 1974

(d) The Nittional Scionce foumdation is authorized to encourage. to tho miximum extent pricticable international participation and cooperation in the development and maintenance of programs of edncation to carrying out the policy of sulisection (a).

\section{TITLE II-IOAN GT'ARANTIES}

\section{WSTABLISIMENT OF LOAX GTIRANTT PROGRAM}

30 USC 1141.

Terms and conditions.

Limitation.

"Qualifjed borrowe $r . "$
Src. 201. (a) It is the policy of the Congress to cncourage and assist in the commercial development of practicaule means to produce use ful energy from grothermal resouress with environmentally arceptahle processes. Acrordingly, it is the policy of the congress in facilitate such commerrial development by anthorizing the (Hiniman of the Projert to designate an appropriate Federal agency to gramranter loans for such purposes.

(b) In order to encourage the commercial production of energy: from weothermal resourres. the head of the designated agency if authorized to, in consultation with the Secretary of the Tieasirry. gun rantec, and to cuter into commitments to gun ranitec, Jenders ngainst loss of principal or interest on loans made ly such lenders to qualified borrowers for the purposes of -

(1) the detemination amb evaluation of the resource base;

(2) resarch and dorelopment with respect to extraction nu

utilization technologies:

(3) acquiring rights in geothermal resources; or

(4) developinent, comstrution. and operation of facilities for thr demonstration or commercial production of energy from geothemal resources.

(c) Any guaranty under this title shall apply only to so much of the principal amount of any loan as does not exreed is percent of the ngerregate cost of the project with respect to which the lom is made.

(d) Joan guaranties under this title slall be on such terms and conditions as the head of the designated ayency determines, except that a guaranty shall le made uncler this title only if-

(1) the loan bras interest at a rate not to exceed such annun per centum on the principal obligation outstanding as the head of the designated agency determines to he reasomable, taking into account the range of interest rates prevailing in the private sector, for similar loans ancl risks by the I nited States:

(2) the terms of such loan reumirn full repayment over a perion not to exceed lhirty years, or the useful life of any physical asset. to be financed by such loan, whicherer is less (as deternined by the head of the diesignated agency):

(3) in the judgment of the head of the designated agrency, the amount of the bo:n (whon combined with amounts arailabje to the qualified borrower from other sources) will be sufficient to carry out the project; and

(4) in the judginent of the head of the designated agency, there is reasonable assurance of repayment of the foan by the qualifed borrower of the gritarautecel indeliferduess.

(c) The : mount of the grnaranty for : any loan for a project shall not exced $\$ 25,0(10),(00)$, and the amouit of the guarnnty for any conbination of lo:uns for any single qualifiel Lorrowrer shall not exceed $\$ 50,000,000$.

(f) . Is ued in this tille, the term "qualified lomrower" means any public or private agency, institution, uscociation, partuershi, 
September 3,1974 -9- Pub. Law 93-410

corpmation, political suldivision, or other lecral entity which (as determined by the head of the designated agency) has presented sat isfactory evidence of an interst in geothermal resoures and is copable of performing research or completing the development nut production of energy in an acceptable manner.

\section{PA JMENT OF INTRKH:ST}

Sx: 202. (a) With respect to :my loan guaranted pursuant to this title, the head of the designated agener is anthorized to entre into a contract. to pay, and to pay, the lender for and on belualf of the borrower the interest charges which berome due and payable on the unpaid balance of any such loan if the heal of the designiated agency finds-

(1) that the borrower is umable to meet interest. charges, aml that it is in the public interest to permit the horrower to continue to pursue the purposes of his project. and that the probablin net cost to the Federal (tovernment in paying surh interest will $b_{x}$. less than that which would result in thic crent of a defant; and

(2) the anount of such incerest clanrges which the head of the designated agency is authorized to pay shall be no greater than the amount of interest which the lontrower is obligated to pay miler the lonn agreement.

(b) In the event of any default by a qualified borrower on a guaranterd loan. the head of the designated agency is authorized to make payment in accordance with the guaranty. and the Attorney (ieneral shall take such action as may be appropiriate to recover the amounts of such parmests (including any payment of interest under subsection (a) fromi such assets of the defaulting borrower as are associated with the project, or from any other surety included in the terms of the guaranty.

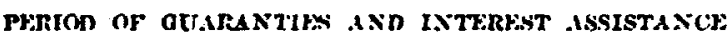

Src. 203. No lonn guaranties shall be made, or interest assistance contract entered into, jursuant to this title. after the expiration of the ten-calendar-year period following the date of enuctment of this Ast.

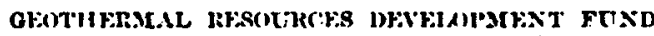

Sec. 20.4. (a) There is pstallislied in the Treasury of the United States a Geothermal Resources Derelopment Fund. which shall be available to the head of the designated agrency for carrying out the loan guarmy y and interest assist nnce progrnum authorized by this title, including the parment of administ rative expenses incurred in commection therewith. IIneys in the fund not needed for current operntions may, with the approval of the secretury of the Trensury. be invested in bonds or other obligations of, or gua ranteed by, the linited States.

(b) There slatll be paid into the fund the amounts appropriated pursuant to section 304 (c) and such amounts as may be returned to the Tinited State's pursuant to section 202 (b). and llie umounts in the fund shatl remenin availahls until expenderl. except that after the expiration of the ten-ycar period established by section 203, such monnts in the fund which are not required to secure outstanding

Contract authority. 30 USC 1142.

30 USC 2143. riment 30 I:SC 1144. 
88 STAT. 108 A

Financial reports, sulm mittal to Congress.

30 USC 1161.

Reports to President and Congress. 30 ISC 1162.

30 USC 1163.
Pub. Law 93-410

$$
-10-
$$

September 3, 1974

guaranty nhligations shall be paid into the general fund of the Treasurip.

(c) liusiness-type financial reports coveriner the operations of the fund shall be subinitted to the Congress by the hual of the designated agency anmunlly "pen the completion of an appropriate account ing periokt.

\section{TITLE III-GFNER.I, PROVISIONS}

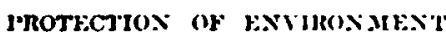

Sr:c. 301. In the conduct of its activities, the l'roject and any participating public or private persons or agencies shall place particulatr emplasis upon the objective of assuring that the curiromment and the safety of persons or property are effectively protected: and the prograni umber title I shall incluile such special reseurch and developunent is may be necessary for the achievement of that objective.

\section{REPORTING RKQTIIR:MY:NTS}

Src: 302. (a) The Claairman of the I'roject shall submit to the President and the Congress full and complete annual reports of the activities of the Project. including such projections and estimates as mny. be necessary to (evaluate the progress of the national geothermal ruer. resenrch, development, and demonstrat ion mogram and to provide 1. basis for as acrurate a judgment as is possible concerning the extent :which the olijectives of this Act will have leen arhieverl by June 30. 1980.

(b) Do later than one year after the termination of each denonstration project under section 10.5, the Chatiman of the Project shall submit to the l'resident and the Congress a final werort on the activitios of the Project related to cach project. including his reconmendations witl respert to any further legislative, administrative. and other actions which slonld be taken in support of the oljectives of this Act.

\section{TRANSFH: OF rexerions}

Sre. 303. (a) Within sixty days after the effective date of the law curating a permmuret Frderal organization or agency having jurisdis: tion nver the enerery resen reh and levelopment functions of the tinited States (or within sixty days after the date of the enactment of this Aet $j$ the effertive date of such law oreurs prior to the date of thi enactment of this Act), all of the rusearch. development. and demonstration functions (including the lo:un guan:unty program) rested in the Project under this Act, along with related records, documents. personnel. obligations, and other items to the extent necessary or appropriate, sha!l, in accordame wit! regulations prescriber by the

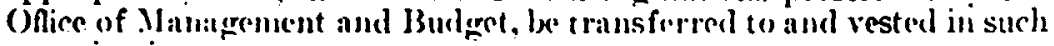
organization or agency.

(b) Upm the establishment of a permanent Federal organizntion or agency having jurisdiction over tice (nergy asearch and devolop)nent furctions of the United States, and when all researeh and dovelopment. (and ofther) functions of the Project are transferred, the members of the l'roject may provide advice and counsel to the head of such organization or agency, in accorlunce with arrangements made at that lime. 


\section{September 3,1974 - 11- Pub. Law 93-410 \\ AUTHORIZATIONS OF APrROPRATIONS

SEc. 304. (a) For the fiscal years ending June 30, 1976, and Septcin- 30 usc 1164 ber $30,1977,1978,1979$, and 1980, only such sums may be appropriated as the Congress may hereafter nuthorize by law.

(b) There are authorized to be approprinted to the National Aeronautics and Space Administration not to exceed $\$ 2.500,000$ for the fiscal year cnding June 30,1975 , for the purpose of preparing the program definition under section $102(\mathrm{a})$.

(c) In addition to sums anthorized to be appropriated br subsection (b), there are authorized to be uppropriated to the fund not to cxeced $\$ 50,000,000$ annually, such sums to carry out the provisions of the loan guaranty program by the Project under title Il.

Approved September 3, 1974.

LEGISLATIVE HISTORY:

HOUSF REPORTS: No. 93-1112 (Ccrm. on Solence and Astrerautics) and

No. 93-1301 (Comr. of Cerference).

SENATE REPORT No. 93-849 accorpanyine S. 2465 (Ccm. on Interior and Insular Affairs).

CONGRESSIOHAL RFCOR, VO1. 120 (1974):

July 10 , considered and passed House.

July 11, considered and passed Senate, anicnded, in lieu of S. 2465 .

Aug. 20, Senate agrted to conference report.

hug. 21, House agreed to conference renert. 


\section{APPENDIX H \\ GEOTHERMAL LOAN GUARANTY PROGRAM RULES \\ AND REGULATIONS}




\section{rules andrequidions}

This section of the FEOERAL REGISTER conteins regulatory documonts hoving general spplicability and legal effect most of whlch an heyed to and codified in the Code of Federal Regulations, which is published under 50 tilles pursusent to 44 U.S.C. 1510 .

The Code of Federel Reguletions to sold by the Superintendent of Documents. Prices of now books sre listed in the first FEDERAL REGISTER Issue of each month.

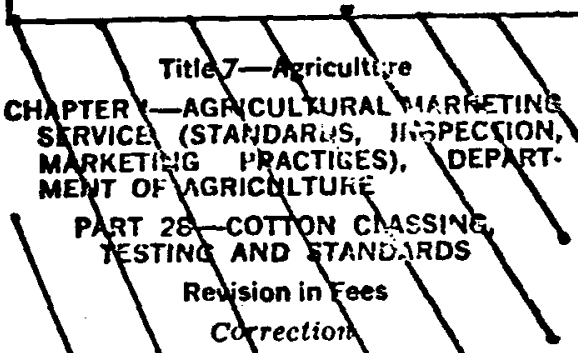

In FR Dod 70-14839 appdaring do page 20680 in the issue of Inurstay, Mhy 20. 1976, the follqwing chrrectioss should be Hade:

1. On Ange 20,382 in tie secont colum. in tem nt. 5 the third yine shotud reac. "mblhod for elther zeto or" apd the sevepth lint should read six spccimens fromb blenged".

2. dn page 20683. in iten no. 24 (d) in the thid coltmn the thirdine should repd. "100-gras spectmen". Title 10-Energy

CHAPTER HI-ENERGY PESEARCH AND DEVELOPMENT ADMIIJISTKATION

PART 790-GEOTHERMAL ENERGY RESEARCH, DEVELOPMEIIT, DEMONSTRATION AND PRODUCTION

Federal Guarantees on Loans

On October 28, 1975, the Energy Re search and Development Adrinistration (ERDA) published in tlie FEDsRaL FEGISIER (40 FR 50100) a proposed regulation concerned with enabiing leuders to obtain Federal guarantees on Juans to qualined borrowers for purposes related to the commercial development of practical means io produce ciectric poxer and other forins of useful criargy from geothermal resources in an chvironmentally acceptable manner.

Generaly, the proposed resulation provided priorities and crtteria whlch ERDA Intends to apply to the consideration of applications for, sind granting or denial of, Federal lonn fuarantccs. Further the regulation provlded illustrations of Information to be ceveloped by the borower and the lender, and to be sup plied to ERLDA, includis a detailed description of the profect for which the and guaranty are rcquircd and an athrmation by the lender simporting the nec essity for the Federnl suaranty.

In nddition, the restuation contained ulustrations of cost llcins whtch would be acceptable for Incluston in the computation of the coseregate cont of $n$ project.

Intercted persons and Federal agencles were neked to comment and a pertod extending from the date of pulslication of the proposed regulation to December 12. 1075, was allocated for such purpose. Ap- proximateiy sixty responses to the requcst for comments were recelved from the public and other Federal arencles. Genernlly, these coinments were directed to the subject of cligible loans and priorities; defuitions; loan guaranty cri teria; supporting information: projec costs illustrations; and, environmento considerations.

The comments, whlch were thoughtfu and provocative, were considered thoroughly and many of them are incornorated in this final regulation. Section 290.4(b) was amended to provide a pref erence for small publlc and private utilities and small independently owncd and operated businesses (as delined in s 790.5 (i) and (j) ), and $700.32(f)$ was inserted to permit the Administrator to allocrte a portion of the amounts avall able for guarantees to such borrowers. A new section, $\$ 790.46$, was inserted to pro vide for future coordination betrees ERDA and the Department of the Interor regarding matters involving the loan guaranty program and lcase admintstralion under the Genthermal Steam Act of 1970. Another section, 790.47 , was estab lishcd to providc bormoryers and lencers with an ability to appeal decisions of the Manager to ETSD's Board of Contract Appeals. The requirement at $\$ 790.20$ in the proposed regulation for lenders to have available during preltminary dis cussions with the Manager an asscssment of all aspects of the borrower's loan appilcation was amended to provide a \$ $790.21(a)(23)$ for the submission of such information torcther with other in formation submit:cd with the guaranty application. In addltion, a number o other changes have been made to im prove clarity.

Therefore, ERDA herewith publishes this Part 790 under which it will administer its geothermal Joan guaranty proEram. Part 790 is added to $10 \mathrm{CFR} \mathrm{Ch}$ III to read as follows:

\section{Subpart A-General Provistons}

790.1 Purpone.

790.2 Objectlves.

700.3 Enective dnte.

700.4 Elatble loans and prioritles.

790.6 Dofnitione.

i90.0 Loan guaranty criteria.

790.7 Interest ersibtance.

700.8 Default payment.

700.0 Perlod of guarantees and Intereat mosistance.

790.10 Information for Governors.

$$
\text { Subpart B-Applicatione }
$$

720.20 Fuing

ro21 Bupporting Information.

700.22 Project cost Jllustration.

Envtrununental conasderation.

700.21 Mandutory purchase of Dood ingurenco.
Subport C-Sorvicing and Closing Bec 790.30 Loan servicing by lender. 700.31 User charge.

790.32 Geothermal resources developmen. lund.

790.33 Prolect monitoring.

790.34 Ionn disbursements by lender.

790.35 Batisfactory documentary evidence 790.36 Withdrawal of guaranty.

780.37 Defnult and demand.

790.98 Preservation of rollatcral.

790.99 Trestment of payments.

790.40 Assigument and incoutestability.

79041 Survival of guaranty agrcemeni.

780.42 Sectirlty with respect to borrowt: Sectirity assets.

700.49 Other federal assistance.

700.44 Patent and proprietary rights.

700.45 Closire.

790.46 Suspension, termination, or cancella tion of operations or production on Federal land admintstered by th Becretary of the Interict.

700.47 Appeals.

AtTHORTT: Bec. 105 (a) of the Energy Re organtzation Act of 1074, Pub. L. 93-438; Tit $U$ of the Geothermal Energy Research. Ir velopment, and Demonstration Act of in: Pub. L. 93-410: E.O. 11834 dated Janunry 1: 1976.

\section{Subpart A-General Provisions}

\section{\& 790.1 Purpone.}

The purpose of this repulation is 1 set forth policies and procedures undc which lenders may nbtain a Federal pua: anty on loans related to the commerch: devclopment of practicable means to pro duce, with environmentaliy acceptab: processes, useful energy from gotherni? resources.

\subsection{Objcctives.}

The objectives of the Fcderal geothe:mal loan guaranty program sre: (a) $u$ encourage and ass!st the private and put lic scclors to accelerate devclopme-t $a$ geothermal resources with environmentally acccplable processes by enabling t: Adininistrator of the Fuerfy $R A$ search and Development Administratir: (ERDA), in the-exercise of reasona fudement, to ininimize a lender's financlal risk thint is associated with the in troduction of new geothermal resourci: and technology; and, (b) to develop nor mal borrower-lender relationships whict will in time encourage the flow of crea so as to assist in the development of renthermal resources without the need fo: Federal assistance.

8790.3 Efrective dutc.

This regulntion is effective June 25 1870

8790.4 Eligible lown and prioritles.

(B) The Administrator mny enter Int agreements to guaranty lenders againi: 
the loss of princlpal and accrued Interest on loans made by such lenders to gunilfed borrowers. Any such agrecmonts shall be made subject to the application of prlorities and preferential consideratons for euarantees as set forth in para. sraph (b) of this section and subject to critcris in 790.6. Buch akreements can be cutercd into only for the purposes of:

(1) Determination and evaluation of the coinmercial potential of geothermal resources:

(2) Research nnd development with respect to geathermal extraction and ut1lization technologies, including but not limited to the mitigation of adverse environmental effects;

(3) Acquisition of rights in geotherma resources; or,

(4) Development, construction, and operation of equipment or tacllitles for the demonstration or commercial production of enerey (e.g.. electric power. industrial or agricultural processes, or space heating) from geothermal resources.

(b) In complying with the objectives of the Federal geothermal loan Euaranty program, the Administrator will give first priority consideration to those applications for projects having a plan of operations which show promise of quickly resulting in the development of useful energy from geothermal resources. Second priority consideration will be given to those applications for profects designed to demonstrate or utllize new technolorical advances or engace in the production of advanced technology components. Third priority will be given to profects that will demonstrate or exploit the commcrcial potential of new geothermal resource areas. The Administrator will give lower consideration to applications involving projects that inttially propose geological and geophysica exploration, or the acquisition of land or leases. WIthin each catczory of priority as described herein, the Administrator will give preferential consideration to those applications in which the lender is providing a portion of the loan for which a guaranty is not requested. Additional preferential considerition with in cacls priorily category will be given to those applications involving. (1) projects from which the Federal povernment will recelve royalty payments, and (2) profects to be carrted out by' small publte and private utilities and $8 \mathrm{~ms} / 1$ independently owned and operaled businesses.

(c) A loan application which mects a lender's standard without a Fedcral guaranty will be regarded by the Administrator as not eligible for a loan muaranty under this regulation. No loan shall be Runranteed if the income from stich loan or the income from jbligations issued by the holder of such loan is excluded from gross income for the purposes of Chapter I of the Internal lievcnue Code of 1954. In indittion, a projert which is devoled ixclusively to the cxtraclion or production of pecothernul byproducts as defined in $\$ 780.5(b)$, or is devoted exclusirely to the desalination of geolhermal brines will bc regarded by the Administrator as not ellsible for a Fedcral loan guaranty under this regulation.

\subsection{Defindtione.}

For purpoeen of thle resulation:

(n) "Oeothermal resources" means (1) all products of ceothermal processes, embracing Indigenous steam, seopreskured fulds, hot water, and brincs, (2) sicam and other gases, hol water and hot brines resulting from water. Bas, or other nulds artinctally introduced into geothrrmal formations, and (3) any byproduct derived from them;

(b) "Brproduct" means any mincral or minerals or gascs which are found in solution or in associntion with geothermal or gcopressured resources and which have a value of less than 75 percent of the value of the geothermal stcam and assoclated geothermal resources or are not, becaluse of quantit.y, quallty, or technical difficulties in extraction and production, of suffictent value to warrant extraction and production by themselves:

(c) "Administrator" means the Administrator of the U.S. Energy Research and Development Administration (ERDA) or a representative authorized by the Administrator:

(d) "Manager" means the Mnnager of ERDA's Ban Francisco Operatlons Office. 1333 Broadway, Oakland, Callfornia Q4616. or a reprcsentatlve authorlsed by the Manager:

(e) "Lender" means any legal entity formed for the purpose of or engaged in the business of lending money and heving the capnbility of servicin: the loan. Examples of Ienders include, but are nct limited to, commercial banks. savines and loan institutions, Insurance companies, factoring companies, investment baniting organizations, institutional Investors, partnerships, venture capital investraent companies, trusts, individuals, or entities designated as trustecs acting on behalf of bondholders or other lenoers:

(1) "Quallied borrower" (herelnafter referred to as the Lorrower) means any public or private agency. Institution joint venture, linited partnershtp, as sociation. cocjerative, partnership, corparation, incividual, political subdivision, or other lezal entity havine authority to enter into a loan asreement. Examples of borrowers inclucie, but are not limiled to. leaseholders, landonners. public and private electric utilties. reservoir developers, drillers. suppliers, component and equipment manuracturers, research and development $n \mathrm{rms}$ engineers, viatent holders, and licensees:

(g) A "loan" is an obllgation involving a borrower and a lender, evidenced in writing. ms:king avallable to the borron'er money at a s,pecined rate of interest for a limited pcriod of time. The loan instrument may not be capable of conversion into an equity relationshlp with the borrower:

(h) "Project" means an undertaking by the borrower which when completen will result in an Identinable product. eystem. major component or stuity for whtch n ruarket potentially exists. Examples of a project include, but are not limited to. test and production well drilling, power plant construction, equipment manufacturing, zesenreh and devel- opment. construction of transmission unes from a ceothermal power plant, apd other ventures lo utilize geothermal hest to serve as an energy source for nonelec. tric applications, such as crop dring and greenhousing:

(1) A "small public or private electric utility, inchiding its affiliates". 1s, as provided in 13 CFR 121.3-10(d) (11), \& bustness concern primarily engaged in the generation, transmission and/or dtstribution of electric enerzy for sale whase total electric output for its precedinp fiscal year did not excecd four mlllion megaviatt-hours: and.

(j) A "small business, Including its amiliates", is, as provided it 13 CFR 121.3-11(B). a concern which is independently owned and operalcd. is not dominant in tts fleld of operation, doss not have assets exceeding $\$ 0$ million, does not have net worth in excess of 84 millIton, and does not have an average net income, after Federal Income taxes, for the preceding two yenrs in excess of $\$ 400,000$ (average net income to be computed without benefit of any carryover lass).

\section{\$ 790.6 Loan gumranty critcria.}

In addition to mecting the requirements for eligibllity set forth in 8790.4 (a), a gursanty may be marle only if the following conditions are met as determined by the Administrator upon the written recommendation by the Manager:

(a) The application is signed by an authorized official of the lender and the borrower:

(b) The Joan is to be made to a quallfied borrower;

(c) Except as provided in 8790.43 , the cuaranty as to princlpal shall apply oniy to so much of the principal amount of the loan as does not exceed 75 pereent of the estimated aggregrte cost of the profect with respect to which the loan is made. Flowever, there is no prohibition against the guaranty boin: equal to $100 \%$ of the loan to be made by the lender:

(d) The Iender has set forth reasons why the loan would not be made to the borroxier without a Federal loan guaranty:

(c) There is satisfactory evidence demonstrating that the lender is competent to administer lonn terms and conditions, and is competent to administer terms and conditions in the guaranty agrecment that are applicable to the lender:

(f) When the maximum permissiblo cuaranty is requested as provided in pararraph (c) of this scction, the lende: has set forth those reasons it is untilling to undertake a loan having less than the maximum permissible guaranty so as to permit the Aranager to cvnluate whether the preferential consideration provlded in $790.4(\mathrm{~b})$ is applicable;

(b) The loan bcars interest at a rato not to exceed an arnual percent on tho princlinal obligation outstandiug as tho Admunistrator detcrmines, in consultathom with the Secretary of the Treasury. to be reasonable, taktife into account tho range of Interest mies and lending pmctices prevalling in the private sector for 
Imilar loans and riste by the Onlted Btates. However, it is expsatid that the borover and leuder ptit $\mathrm{ri}_{\text {i }}$. pilate a mubully eccepialile lntarest rits tizat recombes the basefits to tho lerier from a Tederal suamnty:

(h) The terms of such loan require full repayment over a pertod of no more than thirty ycars, or no lonfer tran the expected aversge useful llie of any major physical asset to be fnanced by such loan, whlchever is less, as determined by the Administrator.

(I) The amount of the loen together Fth other funds avaliable to the borrower wlll be sufficient to carry out the project:

(j) There is reasonable mssurance of Dayment of interest and repayment of the suaranteed portion of the loan by the qualtied borrower, wuch as evidence that there exists or will exist a maricet for the profect's product or results that is sumclent to enable the borrower to repas the loan:

(k) The amount of a curranty for any loan for a project does not exceed \$25. 000,000 :

(i) The total dollar amount of guarntees made under this :erulation for ans comblizatinn of outstand!ng loans to any sinele rualifted boriower coes not exceed \&50,000,000

(m) The project is to be performed in the United States, Its terrilortes or possessions, or on property owned or leased by the United States ouliside the United Btates, Its territcries or porsesslons:

(n) The project is tecinntcally feesible and uses cnvironmental's acceptable processes;

(o) There is sufinclent evidence, such as is provided in a plen of operations. that the torrower will inltiate and complete the project in a tisnely and effcient manncr:

(p) Thare is a suffelency of cncouraging geophysical, geclorical, hy'drological and gcorhicinical cistu;

(a) The borrozer arrees to make svallable on a timely ra...s eny trihnical or econoinic informstion as upecifled in the guaranty akreencia, bud, subject to

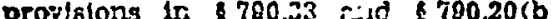
(ii). further agrees to tize use of such informalon for publle diseminntion purposes:

(r) There is satisfactory evidence of the borrower's intercat in scothermal resources:

(s) There is satisfnctory cvidence tinat the borrover is capable of completing the project in an accoptahle manner;

(t) Tlec project, Nhluther conducted on Federal, Slate-ouncd. of private land will be carried out wlth fill reprerd to the use of environments:lly acceptable processes in such a maluuer is to mitigate adverse civtronmental Inupact to the maximum extent prneticslide:

(u) The environmental risks of the profect have been evaluated in accordance viltis 790.23:

(v) The lerms and condilions set forth in the loan ngreement ure acceptable to the Admintstralor; ond.

(w) The borrower nnd any non-gunranteed kinder abroc in wriling that: (1) the termis and conctitions forth in a

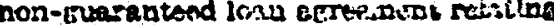
to the projest ahall bu naceplanie to che hominitoinator, and (a) his noil-kuarchtwol loan chall be eubcrilnats to the suranteed lona.

\subsection{Intcreat anciatumea.}

WIth respect to ans loan guaranteed pursungt to this regulation, the Hanafer may enter into en Interest assistunce contrect pitt. the torrower to pay, and to pay the lander for and on behalf of the borrower the interest charges which become due and payable on the unpaid balance of any such loan if the Manager finds:

(a) That the borrower is unable to mcet interest charges, and that it is in the public Interest to permit the borroner to continue to pursue the purposes of the project, and that the probable net cost to the Fecieral government in paying such interest will be less than thist vinlch would result in the event of a default:

(b) The amount of such interest charges which the Mankger is authorbed to pay is no greater than the amount of interest which lise borzower is obligated to pey under the loan agreement; and

(c) The borrower anrees to reparment of Interest charges paid by the Federal government including the payment of interest on such charges at an anuual rate to be set by the Xianager in consuitation with the Department of thic Treasury and stated in the interest assistance contract, aud to the payment of any deierred user charge provided in 790.31 (b)

\subsection{Default parment.}

In the event of any default by a borrower in making a payment in accordance with the loan agrcement pith respect to any loan sciaranteed plu'suant to this resulation, and except as provited in 790.7, the fiministrator will, as provided in 8990.37 , authorice the Manager to make nayment of principal and accrued interest in accordance with the Euaranty. Thareupon, the Attome Gencral of the Unllied States shall tree such action as may is approprlato to recover the amounis of sich payments (including any payment of interest under 750.7) from such rserets of the defaulting borrower as are nssociated with the project, (Including jatent and proprtetary rights resulting from the project as provided in 780.44 ) or from any other siurety or securlity bond by or inclueled in Whe terms of tixe fuarninty. Any recovely nchleved by the Allorncy General which exreeds the amount pald to the lender In accordance with the guaranty anteement or interest assistance conlract shall be returned to the borrower, unles: the guaranty agreement provides otherwise.

6790.9 Period of guarantece and intormet annistunce.

No lonn guaranty agrcements will bo made or interest assis tnoce contracts entered into after september 3, 1084. Guaranty arrecments in efroct at that the will continue untal the term of $t$ loan is corroleted or until tho euarant: portion of lise loen is repiald in full $\mathrm{x}$. accrued interest, whlchever occure ti. Interest asslstance contractz in ef. on septsmber 3, 1924, aill remato effect thereafter unth the contract ust explres or the contract is tarminsted :accordance with its provisions.

6790.10 Information for Governors.

The Administrator will, as appropr:ate meet with Governors of directis $\mathrm{B:}$ fected. States, regional assoclations c: Governors, or heads of State seenc. and commissions responsible for trer or environmental matters for the purpose of:

(a) Discussing the status of projec:guaranteed under this regulation:

(b) Identifying means to remove o: mitigate legal and regulatory barricrs to the accelcrated use of geothermal 1 sources: or

(c) Evaluating plens to encourace srow'th in the geothermal incustry.

$$
\text { Subpart B-Applieations }
$$

\section{\$90.20 Filing}

(a) An eppllcation for a loan sus:anty made undcr this regulation must signed by the prospective borrower $c$ lender or their authorized represez:tives and jointly submitled to the k:2. ager who is responsible for processithe application. Information regard: the filing of applications may be obtaini from the Mnuager.

(b) (1) Frior to recelpt of a guarar epplication, the lifanager is authorlieed conduct preliminary discussions prospective lcnders or borrowers WL: Ing to oblain information or advice rs saruing elidbllity for a loan cusera. and compliance with fling intructio:: including the submission of suppert? information as lllustrated in $\mathbf{7 9 0 . 2 1}$.

(2) Subject to requirements of i. and this recrulation, trade scerets, $\mathrm{Co}^{-}$:mercial and financial information, 5 : logical, gcophysical and geostaphlcal iformation and cats (duchudug mas: concerninf wells which the borrov: makes aveilntle to ERDA during the pre liminary cilscusston or at any other tir: throughout the duration of the prof. on a privtieged or confldential basts, wi be so trented by ERDA and will not publicly disclosed without the prior wr:: ten approvkl of the borrower. In order $\uparrow$ assist ERDA in carrying out this prov: sion. Information decmed by the bn: rower or lender to fall arthin one of $t:$ foregoing caterrorics sholl be ddentin and approprlately marked by the bc: rower or the jender.

(c) A suaranty application may $r$ submitted for a project that is divleic into stages or milestones whlch are ut: lized as the basis for assessing the prac ticabllity of procceding to a subseque: phase. However, in the event of fall to proceed to a subscruent phase, ti: Government's llabillty. under the gur.r enty afrecment, will extend only to $L$ amounts disbursed by the lender ar: 
approved by the inanager as provided in \$ 790.34 .

\subsection{Supportine Informelor.}

(a) The lender and bormorer bhrd provide information in sipport of the applicntion such as preseribed by the Manager. The following ltems lllustrate the range of Informalion whlch may be mecded, (dependent upon the type, complexity and cost of the projeet) so as to cnable the Managcr to prenare a recommendation for the Admintstrator's determination, as provided in $\mathbf{7 9 0 . 6}$

(1) Full description of the scape, nature. extent and location of the proposed project:

(2) A witten afirmation by the lender supporting the necessity for a Federal loan guarninty:

(3) Evidence of the borrower's prevous and curtent interest in exploitung the potentinl of geothermal resources;

(4) Evtdence supporting the borrower's ability to complete the project:

(5) Intercst rate to be charged by the lender:

(6) Perlod and amount of the loan and the percent of the project cost to be guaranteed:

(7) A detailed budget-type breakdown of both the cstimated ageregate cost of the project and the amount to be borrowed:

(8) Erddence shoring that the amourt of the loan toncther with equity or other finaucing will be sumcient to carry out the project:

(9) The borrower's plan to pay interest charges and repay the loan. including assuniptions regardiug marketabllity of the profect's results or product:

(10) The aggregate amount of Ruaranty corrmitments and/or Buaranteed loains outstanding made to the borrower under the provislons of this resul:atjon:

(11) Where relevant to the purpase of the loan guaranty. a cony of the borrower's title or lense agreement to the property, supported by title oljinton or other locally acceptable evidence of the borrower's intcrest. on which the project is to be corried out:

(12) Subject to 790.20 (b) (ii), technical informatton and reports, peophysical data, well loas and core data. fnanclal statements. milestone schedules, and maps and charts:

(13) Information coverinf the manarement expertence of cach officer or key person in the borrower's orfinization who is to be associated with the project:

(14) A description of the borrower's manarement concept and business plan. or plan of operations, to be employed in cairying out the project:

(15) A description of the project's technical and ceonomic a assibllity:

(16) A description of the intended sources and amount of capital and th form requity, lonns from principals. loans from the inder. outside nnancins, or (actoring) together with cwidence of a commitment from these sources and copy of ench such esreement, and evtdence of the fuanctal abtults of each cource to bonor jts commituent:
(17) A cops of the Iosn aptecment to bo executed bs the lander and borromer (18) A listing of af-ale arsocisted or to be rswoclated witin the profect. Including appromriate dats as to the useful ilfc of any phrsicnl asset, and any other escurit.y for the loan and kucmnty narmement:

(19) A description of other Federal $\Omega$ narclal assistance (e.g.p drect lnans, cuaranteed lanis, irnnts, contracts) avallable or expected to be made avall able to the borrower in connection with the project:

(20) A description of the processes and methods the borrower plans to utllize so as to comply with $890.23(c)$ :

(21) Coples of all applications when fled, and approvals when Issued by Federal. State and local government asencies, for permits and authoriantlons to conduct operations assoclated with the project:

(22) A descrivtion of the borrower's organization and a cong of the business certifcate, partncrship agrecment or corporate chartcr. by laws, and approprlate authoriaing resolutions:

(23) The lender's witten assessment of all aspects of the borrover's loan ap plicntion in sufncient detsil as nould be completed by any prudent lender consldering a lman without e guaranty. together with coples of Investigations from credlt bureaus, references, banis inquirIcs. and professional orfanizatloos:

(24) Written assurence from guaranteed and, when approprinte to the prosect. non-guaranteed lenders that the loan amounts as $\pi$ ell as terms and coniitions imposed by such Innders will not be altered in any sipniflcant respect without approval of the Administrator:

(25) A description of salaries (and other financlal reniuneration includijg profit shring and stock options) to be paid to offlcers and employess of the torroxer that are, or will be, dircetly as socinted with the pioject: and

(26) Irvitience of consultation conducted by the borrover with appropriate agcneles of any afieated state rezarding the proposed project.

(b) In rddition to supporting informaton lllustrated in (2) above, the Manager may inderendmuly obtain or nej require the Jender to Include with the cunranty application the flling of Insormatlon regarding the Jender as decmed necessary by the Minnager, Including but not $\mathrm{Hm}$ ited to

(1) Description of the lender's organization and a copy of the buslness cerIfleate, partnershlp agreement or corpornte charter, by-lnw's, and appropriute Buthorizing resolutious:

(2) Copies of unvestisations obtained from credit lurenus, refercnce nnd bank lnqulrjes. and profecs!onal assorlationg:

(3) Descriptions covering the manascmerit experience of each ofitcer or bey person in the lender's orgunbration alio is or nill be nssociated with the loan:

(4) A descrijution of the manasement cancept to be emjloyed by the Iender In survellance of the loan; and

(5) When approprtale to the profect. cvidence of the lender's expericnce in curveying the Inanclal aspects of complex technoiogical projects.

(c) Tr:o Jinzarer shall conslder the applicrition and other releiant information and shrll be responsllite for: (1) determining whether the unolication is in complisnce with this renulgtion: (1ii assessing and cvalunting the anancinl technical, covironmental, Inanazement. and marketing aspects of the project and. (iil) recommending to the Administrator auproval or nonapproval of the applicntion. The Manazer cnal inclucie with a recommendation for apiroval a proposed guaranty agreement contalninf: approprlate tarms and concilions pertinent to the profect. The Mannger will provide the borrower and lender wth a written statement setting forth the basls for the Admintstretor's nonapproval of an application.

\subsection{Project cont ilfutratinne.}

(a) The cost elements set forth in paragrephs (b) and (c) of this section are owly for the purpose of illustrating the manner by which the estimated assregatc cost of the profeat enin be determined. It is expected thet 1.:- ist cots nill be accumulated in sccorisnce wit? generally accopted account Lu pinciples and practices which are consistently applied.

(b) Exceot as set foith in maragraph (c) of this scction, rensonable and customary costs pa!d by the borrowcr that are directis connected to the project are senerally permitted in cosiputing tha estimaled asgregate proiect cost. There costs include, but are not limided to the folloring:

(1) Eniployecs' salaries and mger. consultunt fees and other outsite assistance:

(2) Iand purchase or lase pryments. Incluaing reasonable real estite com missions:

(3) Enpinecring fers, nirvis, plats, title insurance, recotils : ires and legal fecs ducurred in corsectivin rith land acnulstelon:

(4) B!ts improvenente, ste rastoration and nbancis!nnoml cosic. sccess roads ant fencius:

(5) Drillins of crpluration well shallow revi-foor wel:? r.:- iest. pro

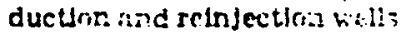

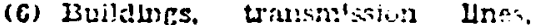
power plant cqulpmert. Rild hiwchinery

(7) Thxes to be palo io 1 'eisarl, Btas and local rovernment aiscuctes ind ollicr taxling allinoritics:

(8) Inturence and bonds of all tspes

(g) Enfincerinm, roinfisnl, archltec tural and legal Iees la: $i:$ in connection with rullitra, machlar:r relection, destm, actulation an:! Iristiblution:

(10) Jzr:asch and caroument necessary to complete the prolert:

(11) Professional frriles and teer neccssary to obtaln llccanc: cod permit and to prepare enviruramental reports and datiz:

(12) Interest cosis charecd by tho ender:

(13) Interest payments to other lenders:

(14) Corts Incurrat bis the borrawer

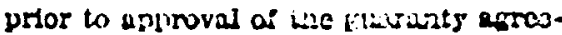


ment that aro directls in connection with the project;

(15) Teebnlesd and noclo-oconomie information dissemination costs:

(16) Costs to provide salety and envtranmental protechon equipnent, facilltles and servicics:

(17) Travel and transportation cosis: fees:

(18) Bond anancing cosks and trustee

(10) Fees for ropalties and licenses:

(20) Costs associated with acquiring geophysical and other technical data:

(21) Financial and legal services costs;

(22) Costs 10 coniply with terms and conditions specined in the euaranty agreement or required by reguialions and issuances bs Frederal. state and local government agencies: and,

(23) A contingency reserve.

(c) Costs which are not considered as project casts and are excluded fmm the guarantecd portion of the loan are lllustrated below:

(1) Company organizational expenses:

(2) Ferent corporation generst and adminlotrative expenses and othcr pirent corporation assessments:

(3) Dividends and profit sharing to stockholders. employees and oficers:

(4) Goodvill, Iranchlises, or trade or brand name costs;

(5) Except as provlded in 790.31, fees and conmissions charged to the borroprer for obtaining loans and Federal assistence:

(6) Loen commitment fees charged by lenders and finders' fees;

(7) Expenses not pald or lncurred by the borrower:

(8) Normal operating expenses incurred after an initial period of start-up: and.

(9) Costs that are excessive or are not directly required to carry out the project.

(d) Indepenciently, or at the direction of the Acministrator, the Maneser may caluse to be performed a reviers of any or all cost elements Incluried by the corrower in the estinited agkreratc project cost The borrotier shaul mate crailable records and other data necesary to permit the Manafer to carry out such revlew, In carrying out this responsibluty, the Manager may utilise empleyees of Federal agencles or may direct the borrower to submit to a review performen by an independent public accountant or other compckert authority.

(e) When costs Incurred prior to the approval of the gusranty aprecmicnt. is provtded in parastaph (b) (14) of this section, are included in the crtimated aggreante project cost. the borrower will make available to auditors selected by the Manmer financial and olher records necessary to coinplete an nudit of such costs if requested by the Manager.

8790.23 Fenvironmental eorsidrentions.

(a) For a proposed profect belng acuvely contulered for a lonn muaranty for whlch an environmental statement or negatlve determination has been prepared by a responsfible Iredr:ral oflactal. the environmentill statement or ncastive determlashou and supporkins wisessmcnt will be utluted by the Meumger and the
Adminiztrator in considering the environmental consequences of the profect. (b) With respect wo rsibh project being considered actipely for a loan puarants for wintch parastutith $(\Omega)$ of this cectlo: is nol appltesble, the Kinnager. in necordance with 10 CFR Pert 711, shnll assess the potential effect of all phases of the project on the humin environment. including but not limited to ash and other aquatic resources, willife habllat and populations, aestheties, recreation, sir and rater quallts, land use, and olher resources to the ares. Thls assersment will additionslly consider, when appropriate to the project, the potential impact on the environment from the collstruction of power plants and transmisslon liwes which may later be required but are not included in the project.

(1) To ald in the nhove assessment the Manager may requcst the views and yecommendations of Federal, Btate, and local government agencles, environmental and industrial orrentzations, and others; and. when approprtate, may hold publle hearings after fiving ciue notice.

(2) If as a resuit of the above asscres. ment, the kiranger determines that the proposed project will have a motentlally simificant effect on the quallty of the humon envirosmest, fral action on the guaranty appllcation shall be beld in nbeynace unt: an environmental staiement in sccorciance with section 102 (2) (c) of the Nationa! Environmental Polles Act of 1959 has been preporer and Issucd bo the respons!ble federal offrial.

(3) If the Mrenager determines that the propesed profect will not have a potentlallp simincant effecl on the quality of the human environment, a negative de. termination shall be prepared by the Manneer and submitted, together $\pi$ ith the arsesment, to the Administrator prtor to final action on the guarsatu snplication. The negative determalnation together with documentstion supportins that determinntion shail be kept on flle by the Mnnager. Environmental nsresements and negative disierminations prepared in compliance vitss this resulation shall to placed in ERDA Public Documant rooms.

(c) Bach loan purranty arrenment shall include the following gencral terms and conditions for the protection of the environinent:

(1) the borrower shall comply with all applicable F'cderal, Sinte and local renuircinents with resoent to the control of ats, land, rater, and nolse pollution. In tlec absence of renuircments, the Manarer, alter consultation with appropriate Feteral. State, and local government secuctes, may reconmond requirements for the Adminlstrator's consideration and the borrower shall comply with such requircments as are approved by the Adintnistrator.

(2) The borrorer, in addition to any other action required by Federal, Gtate or Joral requiremeriss, or requiremen:s estublished by the Adininistrator, or conditions set forth in leases lesued bJ an axcncy of the Federal sovemment shall take the following apectic actlons:
(For purmoses of this parnest th the anpropriate arency oufetal means the Manarer for profnets enaducted on private or Stete-orned land, and the Head of a Federal asency for projects conducted on any land administered by any arency of the Federal roverament.)

(1) Conduct onerstions in such is manlner as to minimize disturbance to veretation, dratnage chansels and streambanks, and emplos ruch soll and recource conservalion and prolection measurcs as are dcemed necessary by the appropriate afency officlal:

(i) Remove or dispose of all wiste gencrated in connection atth the project in a manner acceptable to the appropriate agency offcial;

(iil) Take sill reasonable prccautions necessary to minimize to the maximum extent practicuble jand subsidence or selsmic activity which could rcsult from the profect. including the taking $c$ i measures to monitor oneratlons for land substdence and seismle artivfty and. when requested hy the o:sroprlate arency of ficlal, make afnimale records of all rronitorin activftiss:

(tv) Take gesthetirs into account in the pianning, design, and construetion of facllities:

(v) Employ such measures as RTC deemed necrssary br the nippropriato azency offeclal to protect fish and wildlife and their habitat:

(vi) Condust actrittles on knokn nr suspested archeological; paleoritological, or historical sites in accoróance witi specifo instructions issued bo the appropriate smency offelal:

(vii) Provide. in a timely manner, for the reasonable restoration of all oisturbed lands, mcluding the plucking of abandonad fells: and promntiy empley corrective measures whencrer ecyerse environmental effects exceed those cxpected: and

(viji) Emoloy such cther mestsures as are donmed necssser; by the abompriate ageser infetal to protset the quality of the huxin entronment.

(d) For protects conducted on private or State-oumed land:

(1) Assuring conollance orith the requireme:ts set forth in narngtaph (b) of this section shall be the responsiollity of the Manager. who may ullite experts from frederal agencies. Na!lonal Laboratorles of private firms, and shall havo access to resorts prepared hy the bo:rorrer in enmpliance with lectuirements Imposed ho Frderal, State and local government arrencies.

(2) The borroner shall submit an annual report to the londer and the Manaeer siving a full account of actlons taken to comply with the reauirements set forth in paragraph (c) of tizls scctinn.

(e) For profects to be conducted on any land sdministered hy an agency of the Federal rovemment:

(1) Assuring complianes with salety and opn-roting ninsedures and critironmnntal protection -nquienrionts - nall ho the is nonillustly of the a "pres: Federal nacney or a represcui.tive : thorized by the Head of that axencs. 
(2) The borrower whall provide to the lender and the Manager a copy of eanh annual environmental compllance report prepณred by the borrower in accordance witl reaulations lssued by the appropriate Federal agency.

(f) Nothing in this regulation shal be construed to modify requirements imposed on the borrower or lender by Federal, State and local government apencics in connection with permits, llcenscs, or other authorization to conduct or flnance seothermal activities.

6790.24 Mandatory purchase of Llood insuranre.

The Flood Disaster Protection Act of 1973 (Pub. L. 92-234) may require purcliase by the borrower of flood insurance as a condition of recelving a guaranty on loans for acquisition or construction purposes in an identined fiond plain area having special flood hazards. Questlons emanating from boltowers or lenders regarding compliance with provislons of the Flood Disaster Protection Act and guldeliniss of the Fedeirl Insurance Administration $\pi$ ill be referred to the Managcr. When the purchase of flood insurance is required, as finally detcrmined by the Manager, such costs can be included by the borrower in the cstimated ageregatc proiect cost.

Subpart C-Servicing and Closing

6790.30 Loull aervicing by lender.

Loan guaranty agrecments approved In accordance $w$ ith this regulation shall provide that:

(a) The lender shall exerclse such care and diligence in the disbursement, servIcine, and collection of the loan as would be excrcised by a reasonable and prudent lender in dealing with a loan without Buaranty:

(b) The Inan agreement shall provide the customary period of grace for the making of any payment of principal or interest. Howcver, the lender shall not grant to the borrower any further extension of time over and above ary period of grace for the making of any payment in whole or in part under the lonn agreement without the prior written consent of the Manarer:

(c) The lender shall notify the Managcr in writine without delny:

(1) That the first disbursement is rendy to be made, torether with evidence from the borrower that the project has commenced or is about to commence:

(2) Monthly. or at other agreed upon intervals, of the date and amount of ench subsequent disbursement under the loan:

(3) Of nuy non-payment by the borrower of principill or inturest as required by the lonn atrecment. if such nonpayment is not cured within the grace period, together with evidence of al)promriate notifications made by the lender to the borrower:

(4) Of any fallure, known to the lendrr. by an intended source of captal to honor ths comnilement:

(5) Of any fallure by the borrower. known to the Jender. to comply with terms and conditions as set forth in the
Joan screement or suaranty asreement; or.

(6) When tho londer belloves that the borrower may not be able to moet any future scheduled payment of principal or interest.

(d) In the ovent the lender retains the option to accelorate payment of the-borrower's Indebtedncss, the lender shall not do so without the prior written consent of the Mannaer.

(e) If the guaranty agrcement so provides, the loan astecment will permit the borrow'er to defer payments of princlpal untll such time that income fram the projest is sufticient to meet this obligation.

(f) Lenders will submit to the Manager perlodic Ananctal statements that report the status and condition of each loan guaranteed under thls regulation. The Mannger will prescribe the frequency, format and content of such statements. However, a report on each loan guaranty arreement entered into under this regulation shall, as a minimum, be submitted to the NJanagcr annually on the anniversary date of the guaranty agreement. Feports $x i l l$ be furnished to the Manager until such time as the guarniteed portion of the loan or interest assistance is repaid.

\subsection{Uecr charme.}

(a) A user charge will be collected annually from the lender imposed on the guaranteed portion of the loan and computed at a rate to be sct forth in the guaranty gareement. The rate shall be imposed on the anticipnted average amount of the guaranteed portion of the loen that is estimated to be outstanding during the year. The user charge may be passed to the borrower by the lender and in such instances may be included in the project cost.

(b) At the time the ruaranty agreement is closed, as set forth in $\$ 79 n .45$ (d). the lender shall present to the Bannaer payment of the first yenr's user charre. Bubsequent payments of the charge will be made by the lender on the anniversary date of closing. If interest nissistance is in effect, payments of this charke, if passed by the icnder to the borrower, will be deferred for the term of the interest assistance contract.

(c) The Administrator annually will evnluate a.hether the user charge mic being impored ts sumicient to cover anticinated ndministrative, deinult and interest assistance costs and, when appropriate, establish a revtsed rate to be applled to new guaranty rogrcements.

6790.32 Gomloremnl Iranurren Drrel. upnieit fiund.

(a) As provided in Scc. $204(a)$ of Pub. L. 93-410, there is established in the Treasury of the Unitusl Stistes a Cimthermal Resources Divelopment Finuni (hereinatier referred to ns the Fund). which is nvailabie to Wie Aclmitistrator in carrylng oul the lonn gunrapty and interest assistance prof.ram contepulnted by this regulation. Including the davment of ndmintstrative expenses tocurred in conncction therewith. (b) Approprtations to the Fund ti aro made avallable through legtelation. reporments made by borrorers in 8 . cordance with terms and conditlons: tnterest assistanee contracts, or amo:m. returned to the United Etates thro:" recoveries by the U.S. Attorney Genrr: as provided in 790.8 , and not disiun $=5$ ? In accordance therewtth, shall, exccF:. otherwise provided by law, be avaljable $t$. the Administirator for the payment lenders of principal and interest on gus:anty agreements and interest assitisin: contracts made in accordance with th: regulation. In addittion, balances in $t:$ Fund may be used for necessary adintnir trative expenses incurred by ERD. other Federal arencies acting pursus:: to ERDA direction in carrying out t... provisions of this rckulation.

(c) In the event of a default, the Mraiager may enter into contracts as quired to preserve the collateral for tr: loan and to complete unfulibled enitio: mental requirements. The cost of kus. contracts may be charged to the Fit:s

(d) In the event that incerest ressis: ance payments and default paynerit: $c:$ haust balances in the Fund, the Adm::istrator will promptly seek to obtain $\varepsilon:-$ propriations as are authorized.

(e) Moncys in the Fund not nerd:for current opcrations map, with t: apjroval of the Secretary of the Ther. ury, be invested in bonds or other ob: Rations of, or guarantees by, the Unit: : States.

(f) Not less than ten percent of th: anount available for lorn guarante? during a fiscal ycar will be allocated guarantees on loans to small public a privinte utilitje's and small independer: owned and obcrated bustarsses, as $c$ fined in 5 700.5. The Administrntor, bis discretion, inay adjust the kiloca:reserved for small concerns. To Uie tent that guarantecs on loans to qualiz: small concerns are not lssued within: months followills the beginninf of ear fiscal year, the ulcommitted allocattc: of loan kuarnntees for sma!l connosi. at the discretion of the Admintsirntmay become nvaliable on an umestrici? basis.

\$ 790.33 Project monitoring.

The guaranty afrecment shall prov! that emplnyecs and represeistatives ERDA shall, Nith the Manager's $\mathrm{A}$ : proval, have sicecss to the prolect in The lender, to tise extent lis ifill as Within its centrol, and borrorer n'ill :? sure availablllty of informntion relair. to the project as is necossary to perm: the Maniager to determine techmi: progress, soundiness of tinatirial cons: tlon, manafecacent stabllity, complian with cnvironmmintal protection requir? ments, and other matters pertinent the guaranty.

\$790.34 Lann disisurnenunntm by lender

Unless otherwise provided in the gus i nnty nereement. the lender shall $\mathrm{ne}$ make any dlsbursement on the lotis untll:

(a) It has followed notiflention $r$ quilereents as set forth in $: 790.30(\mathrm{c}) \mathrm{d}$ 
and (2) and has recelved wrilten notice from the Lifinager that disbursement is approved; nud,

(b) It has recelved from the borrower satisfaclory documentary evidence, as provlued in 8790.35 , that funds requicsted will be used to pay the borrower's cossts incurred or to be incurred for the project.

\section{$\$ 790.35$ Satiafactory documentary evi-} denee.

Tive borrower shall furnish to the lender a written stalement is support of each requiest by the borrower for loan disbursements, sctling forth in such detall as the lender or Mauager may require the purposcs for which disbursement is requested and an atlestation that such disbursements will be used oniy for such purposes. Signature on the requesting document shall be made by a person authorized to order the expenditure of the borrower's funds.

8790.36. Withdrawal of maranty.

(a) The Administrator. may, upon the written recommendation of the Manager. lerminate the guaranty by wittten notice to the lender and the borrower if the Manager Inds that:

(1) Initiation of activity on the project has not occurred within the period of time set forth in the guarinty agreement. Within sixty days after termination under this clrcumstance, the Mifanager shal reimburse to the lender the full amount of the user charge paid by the lender if the charge has not been passed to the borrower:

(2) There is non-complance on the part of the borrower or the lender with material terms and condillons set forth in elther the loan agrcement or the guarants agreement, olizer this those concerning Initiation of activits as referred to In parapraph (a) (1) of this section: or, (3) There is fallu:e by the borrower to acquire capital from intended sources, as provided in $\$ 700.21(8)(16)$, and the borrower is unable to acqualre alternate sources within a reasonable time as may be approved by the Mivager.

(b) If the borrower la:ls to acquire capital froun inlender or elternite sources, of falls to conis: with material terms and conditions s.it forth in the loan or guaranty agreement. the Bianager shall notify the borroxer and the lender that the guaranty way be reduced to the amount that his bern disbursed by the lender as of the date of the notice. Disbursements made by the lender after such nutincation 18 recelved will not be covered by a guaranty.

(c) If the lender fails to comply with any material term or condiltion set forth In the fusaranty or loun agreement. the guaranty may be tcrninnted. Notice of the Manner's Indine that a unate:ial term has not betn complicd with shall be served by the Mianarer upon the borrower and the lensicr. l'ollowing notit?calton, the borrower will be allowed rensonable time to nequirc a substitute lender that is capable of complyinf with provisions in this repulation. If the berrower obtains a subs:titute lender satisfactory to the Adininistrator, a new guaranty agreement will be negotiated.
Opon Issuence of the new fuarants to the substluate lender, the orlginal lender shedl be reiebursed by the burrower for unpaid prtinelpal cutstandiog and acclued interest.

\subsection{Defaull aind demand.}

(a) If the borrower de!aults in makivs payment of princiusl or fitterest within the time period allowed in $\$ 790.30$ (c) (3) and the lender has complied wit! the requircments plincrd on it as set lorth in $\$ 890.30$ and 750.34 , the lentler mas make denand in nitine upon the Manager for pasment pursuant to the Euaranty, subject to the conditions described in paragraplis (b). (c) and (d) of this scction.

(b) The Manager shall, pursuant to the provisions of $\$ 790.7$. determine Whether an interest assistance contract shall be executed. In the crent thint interest assistance is not warranted, tise Mannger shall so nolify the Administrator and the lender. The lender shall make available nithout delay such documents and certifications as the Manager may reasonably requtre evidencins the lender's corruliance uith notifiestion provisions of the guaranty ngreeuent.

(c) Upon default by the borrower and notification by the lender, and to the extent that subicient reserves exist in the Geothermal Lesources Develcrment Fund: (i) upoul approval of the Adinulistrator, the Manager shall, within sixty days after reccipt of sucl documents. pas to the leneer on a proportionate basis or in full. sildichever the guaranty agreement provices, the Eunranteer amount of umbid principal and accrued interest outstajuding at tlec ciate of dicfault: and (ii) curing the period beGinning from reccipt of such cocovients and until pryment is made by tise Nianager, interest payable by the Undi=d Etates will accrue on the puarnntesd dobt at a rate to be determined by tile Secrctar of the Tressury taking into consicirration current aversge murket jlelcis on outstanding short-tern recesury ecclivitles.

(d) The iender shall. concurreutly with payment in full of all ancomis guarantaed by the Unicicd Stales, acsien to the United States and trencfer and deliver to the hisnarser the loan dcenments. together wiin all collate-al documents evidencing any and fill security for and guarantes of the loan then held by the jender as set forth in the lown or guaranty ngreemciat.

\section{$\$ \mathbf{7 9 0 . 3 8}$ Preecsation of collutown.}

Upon default by the borrower, the hutder of collialcral associated with the project sluall talte actions surh ns the Manafer may remsonably require to provide for the care, nreservation, and mainlenance of such collateral so as to achieve muximum recovery upon liquidation of $c$ collateral. eccurity and suartintees for the loan. Exceut as provtded in 85780.37 and $790: 10$, the lender shall not waive or rclinquish, wit!ent the contsent of the Manafer ony erilaternl or minrs, nty for the loan to which the Government would be subror:ated uinen payment under the euaranty isreement to the lender.
\$ 790.32 Tralment of paymeatn.

When the lende: holds a guaranteed and-son-5uErantsed portion of a loan. payments of principal misule by the borrover in accordance witis the loith anreement shrill be apllied by the lender to redice thic cuaranteed and non-murantred portions of tise loan on a proportionatic bissis.

\$ 790.10 Aesignment and incontestabi). ily.

(a) Excent as may be required by lan: the lenter may assirn to another lender rigits and oblisations under the lan or cuaranty agrcement only with the prior written consent of the $A$ dministrator.

(b) The Jender may provide other Icnders with particinating shares in tis lonn without the prior consent of the Adininistisator. Written notice shall be Fiveri by the lender to the Mianarer and the borrower vihen pa-ticipating share are so provided. Fowever, the orjglnal lendler shilli continue th be resnonsible for and periorm the provisions of the guaranty afrecment pcrtaining to the lende: unicis the fdministriator approves a sub. stitute lender.

(c) The guaranty arrecenent shall bo conclusive cridence thint the guarants and the underlying loan are in compliance $\nabla$ ith the provisions of Pub. $L$ 93-4io and this resulation, and that such lung has bren spproved and is leral is ta principal and interest and other term. Euch a cuararty shall be valid and incontesiabie by the Government, exces: for iraud or misrepresentation by the holic: of the obligation.

$\$ 790.11$ Survival of Euaranis aprer. ment.

The guaranty arreemeat shall be binc:ing upon the lendar, the borrower arc the Administrator and upon their sur. cessoits and nesions and shall survive $m_{j}$ menl by the United States. No delay or faiurs of the Aciuinistrato: or the Mali afici un the exercise of any right o: remedy and no single or partial exercis of any such right or jemedy sliall yis. ciude any further pxercise thereof; sil:un action taken or omilied by the sc. minirtrator or the Mariager shall bn demed a walver of auy such right c. remeds.

\subsection{Security with srspeet to bor-} rowcr's asacts.

Each loan gunrantesd under this restlation rill be secured by liens or assipln. ments of rights in asects associated piil the profect, or such other security sirer:fice in the gunsante arrecment as m: be rensonably recuired to protect the iniercsts of the Uniecus sitates. Upon refoulit by the borwowr. as set forth i $\$$ i?o.8, the Attorncy General will sor:

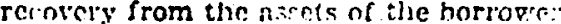
that are associatce with the project o: sipecified in the buatunty aerecment

\section{\$ 790.13 Other Forderal nisinennec.}

(ii) Nothing in this resulation sh:": be in inrpreted to deny or limis the bi:rowris risht to scek and obtain oth Fideral fluancial assistanec ic.t., cont tirets, Erants, direct louss or guarnnte: 
lrans). However, the total anount of Federal fnancial asalatalico, Including grinranices made under this rerulation, oblained by the borrower for the prolect. shall not exceed 75 percent of the ext1mnted argregate cost of the project to be undertaken by the borrower.

(b) Arkr closing of the loan guaranty asreement, the borrower will not undertake any work in connection with the project (by contract or grant) for a Federnl agency without the Manager's written findins that performance of the work will not adversely affect the borrower's ablity to comply with pertinent terms and conditlons in the loan and guaranty agreement.

\$ 790.41 Patent and proprictary righte.

(a) Palents and other proprictary rights accrulng to the borrower and resulting from the proiect will remain with tho borrower, exccpt as such rishts shall be, In the case of default, treated as project assets in accordance with terms and conditions in the suaranty agreement.

(b) The guaranty apreeinent may provide that palents or other propitotary intellectual property rights utilized in or resulting from the project, whtch are owned or controlled by the borrower. shall be made avallable to other domestic parties upon reasonnble terms and corditions which protect the cortidentiallty of information, if such nction is determined by the Admintstrator to be in the public interest. This requirement will not be nceded where the principal purpose of the loen to be guamnteed is to ulillze generally nvallable technology to determine and evaluate a new geothermal resource base, or the acquisition of rights in geothermal resources.

(c) Where the principel purpose of the joan is for rescarch and develorment with respect to extraction and utilization technologics, or for the development or demonstralion of new and unique facliltles or equipment, the requirements for making patents nnd other propsetary intellectual property avaliable to other domestic parties shall norzally be included in the guaranty aprcement unless the Administrator determines, upon the recommendation of the Manefer, tirat such implementition would elther sertously impals the borrower's abillty to conduct the project, serfously impatr the borrower's abi!lty to malntain a market place posture, or be inconsistent with the borrower's pre-extsting contracturd obUgations. The Admintstrator's determlnation on this matter shall include conBldcration of whichier attalnment of the objectives of the geothennal loan gunTanty program, as set lort i in 1790.2 , will be adversely affected by this requirement.

\subsection{Cloming.}

The major activities lending to tho closing of the suaranty agroement inchudo the following: (a) When an arplleation for a loan ruarants has been aDproved by the Adminietrctor, the Manacer will so notify the lender and the borrower and provide them with a cons of the proposed suaranty agreament.

(b) A preclasing conference will be arranged by the Mannzer. If the lender or berrower requests one, to discress the lerms and conditlons contalned in the guaranty agreement.

(c) Irequests by the lender or borroxer for modineation of the tcrins and conditions set forth in the suaranty arreement shall be submitted 10 the Manacer, supported by such documentatlon and facts as would justify the requests.

(d) Immediately after sgreenent to terms and conditions, the Manager shall arrange with the leeder and the borrower for the preparation and review of nccessary documents and apree upon a date for execution of the guaranty agreement and pasment of the user charge.

6790.46 Sompenulon, termization or canceliation of onerutions or produc tion on federal land adminimtered by the Secretary of the Interioz.

(a) The Manager ahall inform the $\mathrm{Su}$ pervisor (as dellned in $30 \mathrm{CFR} 270.2(\mathrm{c})$ ) when \& loan suaranty is approved tilvolving a Federal lesse, to as to provide for future coordination of the loan gunrenty program and lesse administration.

(b) Under rerulations issued by the Departmeint of Intarlor. a leaseholder mag, as provided in 43 C.T. 3205.3-8 and 30 CF? 270.17, apply for Euspenstion of operationis or procuction, or both under producing genthermal lease for for rcllef from any drillinr cr producing reguirements of such a lease). When \& loan guarenty has been lssued under this reculation for a projest to be conducted by a qualisied borrower who is a leesee under the above cfted regulation, the borrower thall submit the suspension application to the Manascr, together with a stalcment setting forth complete information showtinr the eficet of suph kusperition on the borrower's abllity to comply witin terms and cor:ditions sel forth in the loan agreement. 'The Manaser will notify the borroxer in those siturations when approval of the epplication minht crise cicfoult by the borrower. Except in cases pihere polcnting environment.al safely or reservolr demoge is imrainer.t. the borrower shall obta!n the san:anser's approval prior to cilimitting a suspension epplication to the Eupervisor.

(c) \&3 CFR 3204.3 rerjulres the.t cach geothermal lease 1sived by the Ihepartment of the Interfor provide for tha readjustument of terms and conditions at not less than 10-ycar intervals besinning 10 years after the datc geotizermal slenm is protuced. Wincn a suarsnty under this resulation has been insijed for a Jonn on a project to be conducled by a borrower who is a lessee, and the bor rower fles an cbjectlon to eny pmpoes

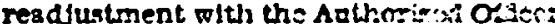
(as delned in 43 CFR $3000.0-x(f)$ ) a cr: of the objection shall be submitied without delay by the borroper to the Manager. The kanager shall fortira a corv of the objection to thase lexders concerned. and shall consult with the $A u$ thortzed Oelcer regarding anl naal ncWon by the Authortzed Oilicer whici might terminate the lense. Tha Managc: shall prepare an assessment on the effect of the proposed readjustment of leace terms and conditions that riculd cubstantially limit the borrower's ablitty to comply with the terms and conditions set lorth in the loan agrcement. Ire kianager shall forwerd his assessment in Irriting to the Admiristrator, the Authorized Officcr and the Supervisor.

(d) Upon receipt by the lessee of notice of a proposed cancellaticn of a lmsc by the Authorized Oriser, the lcrsec witl a loan guaranteed under this reoulation will provide the r.lainurer and the leuder with notice of such proposed action. Opon recelpt of such notice tJ.e sanager will consult with the Bufsrvicor and Authorized Olicer for the purpore of determining whether the publtc interest can best be served by an acceptabie niterna tive arrangement. such as oblaining as sicnments for a party quslined to hold geothermal leases who is a quelified borrower and who is willing to assume the origtnal lessee's loan asteement and related undertaling. so that operation and production can continuc.

(e) If defeult is likely to occur as a result of termination or cancellation of a lease, the Kanager siall request the Supervisor or the Authorizerl Officer to rescind the lessee's priviege of removing assets from the premiscs, es provided in 43 CFR 3244.5.

\subsection{Appeals.}

All decislons by the Manopici relating to disputes arising under a glarantagresment or loan agreenient made under and entered into pursuant to thls rerulation shall be in writing. Tis borrower or lender, as applicable, may reguest th: Manager to reconsider any ench decision. If not satisfied with the finn declslon made by the Mirnager, tlic borrower os lender, upon recelpt of such written decision, mny appeal the dectsion withis 30 dajs, in writing, to the cinurman Board of Contract Apperls (EBCA). Enerry Reserirch and Develoynent Administration, Washington. D.C. 2C545. That Board when functionins to resolve such loan susranty disputci, inall proceed in thic kame genersl manner as when it prestees over appen!s involvin: contrret disiviles. The dcctinin of the Board with respect to such appesls shall be the final dectsion of the Afency.

Bigned at Washington, D.C., this $25 \mathrm{th}$ day of May, 2076.

Ronent C. Erasuns. Jr., Acristristrator.

[FR Doo.76-15162 Fild \&-23 7s;8:48 am] 


\section{APPENDIX I \\ AMENDMENTS TO THE GEOTHERMAL RESEARCH, DEVELOPMENT, AND DEMONSTRATION ACT}


TITIE V-ABENDMENTS TO THE GEOTHERMAL ENEHGY RESEARCH, DEVELOPMENT, AND DEMONSTRATION ACT

Definitions.

30 USC 1101 sole.

30 USC 112

Cairone.

30 USC 1123 .

30 USC 1125.

Wea guareany

progrem.

cenoblintomeat.
30 USC 1141 .
Swc. 501 . As used in this titlo-

(1) the term "Act" meenus the Geothermul Einergy llesearch, (2) ponent, and Detinotist ration Act of 1074 (88 Stat. 1079) i and

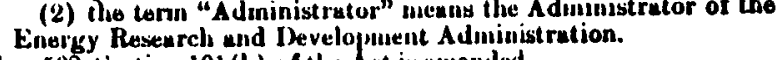

(1) by striking out subparagraph (E) of paragraph (1) and (1) by atriking out subparkigreph

insertiiig in lieu lleres allo fllowing: "(k) the Assistant Administ rator of the Bnergy Research and Advanced Euergy Systems;";

(2) by striking out the period at the and of paragreph (1) and inserting in lieu thereot a sermicolon;

(3) by adding at the end of paragraph (1) the following now ubparagraphs:

"(G) en Aswiet tant Admiuist rator of tho Envimnnental Protoction Agency;

"(II) an Assistunt Secretary of Treasury; and

"(I) un Assistunt Siecretary of A griculture."; and

(1) by blriking out "one member of the Project" in paragraph (2) und inserting in lieu thereof "(lio A ssistunt Administralor of Whe Finërny Research and Ih velopment Adninistration for Soler, Coclsermal, and Advanced vergy Syotems".

Sw. Sal. Section lus (b) (4) of the Act it amended by inserting the phrase "or mouinistrative regulations" after "legialation", and by Sx: sot. Suxction $105(\mathrm{e})(3)$ of the $A c t$ is aneended by triking out

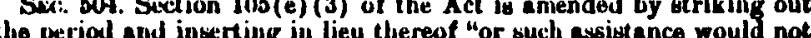

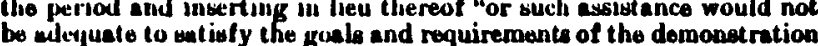
prograus under thix metion".

Bea. D0S. Section 201 (b) of the Act is wnended by st rikimy uut "or" at the and of parweraph (3), by striking out the period at the end of paragraph (4) and inserting in lieu thereof "; or", and by adding at bo and thersof the following new paragraph:

(5) construction and operation of a hew commercial, epriculLural, or indust rial st ructure or facility or modificat tion of an existiny cornmiscial, arricultural or induatring atructure or facility, wholl teochoermol hot water or steasin is to to used within or by such siruct ure or fucility, or modification therbo, for the purposes of ipmen heat ing or cooling, indust rial or - chricultural procetseses, onsite generation of electricity for uso

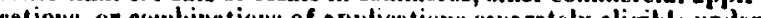
this title for loan guarance assistunce."
Sec. 5ot. Section 201 (b) (4) of the Act is
"frum"

Sxe. 507 setion 01 (c) of the Act is winended by adding at the end Estent of thereof the following new sentence: "In the case of a guaranty for the cuaranty. purposes specified in subsection (b) (5), the aggregulo cost of the project shall be derenied to be thet portion of the tow cuet of construction and operation which is directly related to the utilization of geothermal emergy willin the structure or fucility in question, except that the agrregale coat of the project with respect to which the loan is made inay the the total cost including construction and operation in cases where the fucility or structure has been located near a geothermal energy ressurre predominamt ly for the purpose of utilizing goothermal of the projuct is subutantially dependent upon the performence of the

Suct Section 201 (e) of the Acl is amented -

(1) by striking out "\$25,000,000" " und inserting in lieu thereof "The project shall not exceed $550,000,000$ ".

(2) by striking out "\$\$0,000,000" and inserting in lieu thereot $\omega 200,000,000 "$; ind

(3) by inserting be fore the period at the end thereof the following: ", untess the Adninistrutor determines in writing that * guaranty in excess of theso ambunts is in the mational interest. Any surh itelermination shall be submitted to the spevaker of the House and the Committee on science and Technology of the

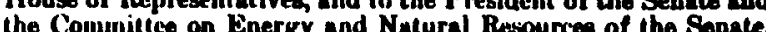
the Committe on Energy and Natural Resources of the Sanate, ect nod antee shiall not be finulizol under euthority granted by this Act prior to the expiration of thirt culender duys (not including any dute on whicl, either House of Congress is not in session) from the date on which such report is recieived by the Spenker of the House and the President of the Sesmite.

Sixc. 509. Section 201 of the Act is further aunended by adding at tho Iavereat payment ind thereof the following new subsections:

"(g) With respect to any guarunty which is issual after tho enectment of this subsection by, or in behalf of, any Stute, political subdivision, or Indian tribe and which is either cuseranteed under, or supported by tares leviod by majd issuer which are guaranteod undor the title, and lor when the int isest paid on such obligation and purvos of clunter 1 of the Internul Hevenue Code for 10 the unnended, the Administrator shill pay to such issuer out of tho fund 26 USC I a $\mathrm{seg}$ ostablished by this titlo such portion of the interest on such oblisations as duturnind by the Administrutor in consultation with the Secretary of the Treasury, to be appropriated after taking into mcount current market yields (i) on obligationus of such issuer, if any, or (2) on other obligations with similar terus and conditions, the intenest on which is not so included in grows incomis for purposes of chapter 1 of suid Cods, and in accordance with auch terms and conditions as the Administrator

u(h) The full fuith and credit of the United Sintes is pledged to the payment of all guaranties issued under llis title with respect to
principal and intereat. 
"(i) The Aduniniserator shall charge and collect feres for guaruntics

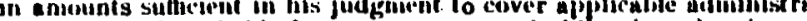

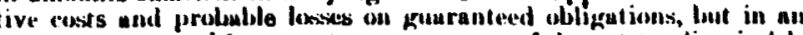

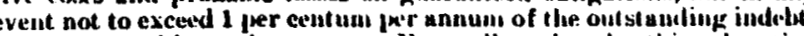
edness coverecl by each guatunty. Feuss collected unter this subsection aliall bo deposited in the fund established by this titlo

Capisal arter "(j) The Secretury of the Trousury shall insmie to the muximum

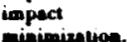
extent feasible that the timing, interest rute, und substantial termis nun conditions of uny gua ranty exceeding \$25, 010,000 will have the mini-

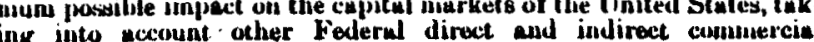
ing into activities?

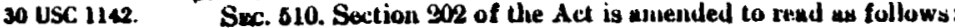

\section{"DEDAULT; PAIMENT OF INTEREST}

"Skc. 202. (a) If there is a defuult by the borrower, as detined in regulations promulgated by the Adninistrator and bet forth in the guarantes cont ruct, the holder of the obligution shull have the right Within such Within such period as may bo specitied in the guarantso or related agretments, the Administrutor sheil pay to the holder of the obligation the unpaid interest on, and unpuid principal of the guaranteed irator finds that there wes no default by the borrower in the payment

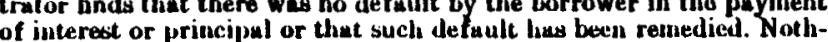
of interesi or principul or that sucli default has been remedsed. Noththe holder of the obligation for the benchit of the boriower which any
twe egreed upon by the parties to the guarenteod obligation and approved by the Administrutor.

- (b) If the Administ rator mukes a payment under subsection (a) of this subsection, the Administ rutor shall be subrugated to the rightis of the resipient of such payment as specified in tho guarantee or related crretments including, where appropriate, the authority (not-

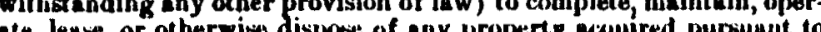
cte, lease, or oht or such gumintes or related agreturents, or to permit the Lorrower, pursuant to an agroentent with the Administ rutor, to continus to pursue the purposes of the project if the Admimistrutor determines tespect to any property mcyuired pursuant to bucli guaranteo or relsted agreemessts, sliall be superior to the rights of any ocher person with respect to such property.

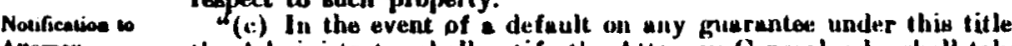
Anormey the Administ rator shall notify the Attorney General, who shall take such setion as miny bo appreopriuts to recover the amounis of any puyments made under sulsection (a), includiug any payment of principul and interest under subsection (d), from such easets of the defu ulting borrower as aro associated with the project, or trom any other
wocurity included in tho corms of the gun rantec.

"d) With respect 10 any obligution guaranteed under this titlo the Administ rator is muthorized to enter into a cout ruct to pay, and to pay, halders of the obligution, tor whil on belanlf of the horrower rom the Coothermal ketources levelopment Fum, the primtipal

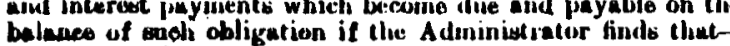

"(1) the borrower is unable to meet such puynents und is not continue to pursue flac purpmes of smell project; and the probable net benctit to the Federal (iovernment in paying such principal and interest will he greater than that which would result in the ovent of a defuult;

"(2) the amount of such puyment which the Administrator is authorized to pay shall le no greater than the mount of principal and isterest whic grectinent; and

such puyment on lerms and conditions, including interest which such puyment on terms and conditions,

Sive 511 Section sot of the Act is anended by redesif ded by redesignating subsec- Notee or lowing new sulsection (c)

"(c) If ut any tion (c): "a coulde the Administrator to discharge his resionsibilities under this 30 USC ilm title, he shill issule to the Secrelary of the Treusury notes or ot her obligutions in such forms and denominutions beraring such maturities, and suljjest to such ternis und conditions, as may be preseribed hy the See. mitury of the Treasury. This borrowing authority sianl be eftective only to such extent or in such amoumts es are sperificd in appropriation Arts. Such muthorizations muy be without fiseal year limitationa. Redemption of such notes or obligations shull be made by the Administrut thom approprialions or ofher monevs available under this Jitermine hy the Sectery of the Treasury, which shall not be lese

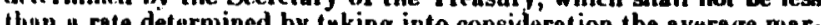
ket yiold on out standing marketahle oblizations of the Iverace marof comparable maturities during the month preceding the issuance of the notes or other obligutions. The Secretary of the Treasury shall purihuse any notes or other obligutions issued hereunder and for that purpasi: he is authorized to use as a public debt transaction the proceeds from the sale of any securities issued under the Second Liberty Bemd Act, ns amendied, and the purposes for which securities may be 31 USC 774 issived under that Act ure extentled to inelude any purchase of such notes or obligations. The Secretary of the Trensury may at any time sell nny of the notes or nther obligations acyuired by him under this sen. sitbsertion. All redemptions, purchases, und sales by the Secretary of the Trensiry of such notes, or other oblignt ".

(1) ind thereof the following new eection:

\section{“COMMUNITY IMPACT ABUINTANCE}

"Sik. 2015. (A) The Administrutor. for any proiect which has a 30 USC 1145 guarantee under this title of not less then $\$: 40,(00,000$ und which wil huvo an ineming oprating life of not jess hian hive yours to satisfy

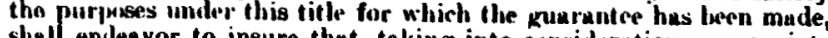
shan enleavor to insure that, faking into consinlerution appropriate

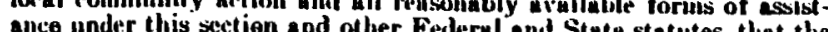

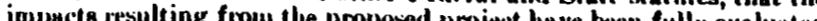
by the Lorrower, the Administrutor, and the Governor of the effected State, and that ceffective steps bave han taken or will bu taken in timely manner to finunce conmunity plunnime and development costs realting from such project under this goction, if epplicable under 
Stace and lowel other provisions of law, or hy other means. When llae projert will he lecaled on leassed Federul lands, the Administrulor shall squeriticully 30 USC 191 roview Siute mund hocal actions under section O(a) of the Mineral

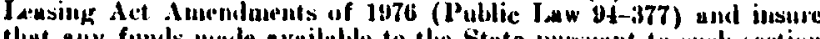

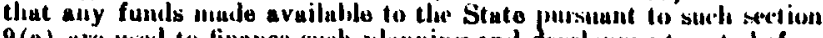

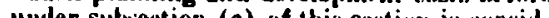
ened of aullurized.

"(b) The Administrator fur projocts not included under. sulveretion

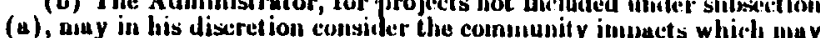

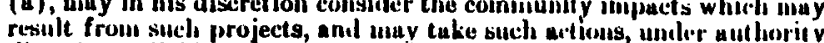
directly avuiluble to him under ofluer statutes or in condination with other fiederal ugencies or the Stute, as he cousiders uneresury umbl appropriate to insure timely and effective planuing and finmeciug for such comminnity impmets

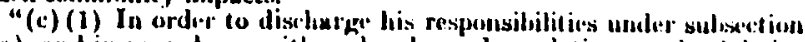
(a), and in mecordance will such rules und regulations ans lhe Admin. istrator in consultation with the Serretary of the 'Treasury sladl

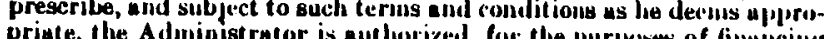

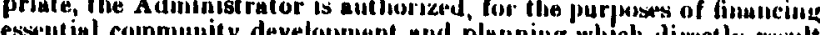

fromi, or are neccsesituted by, a project under subsection (a), to-

Payments.

ment of interest on, and the principal balance of, obliputions for such finencing isaud by oligible Stutes, political subdivisions, or Indiun tribes,

"(H) gurantee and make comnitments to guarumtec the payment of teres imposed on such project by efigible non-Federwi turing suchoritics which taxes are eumnarked by such muthorities to support the payment of interest and principal on obligutions

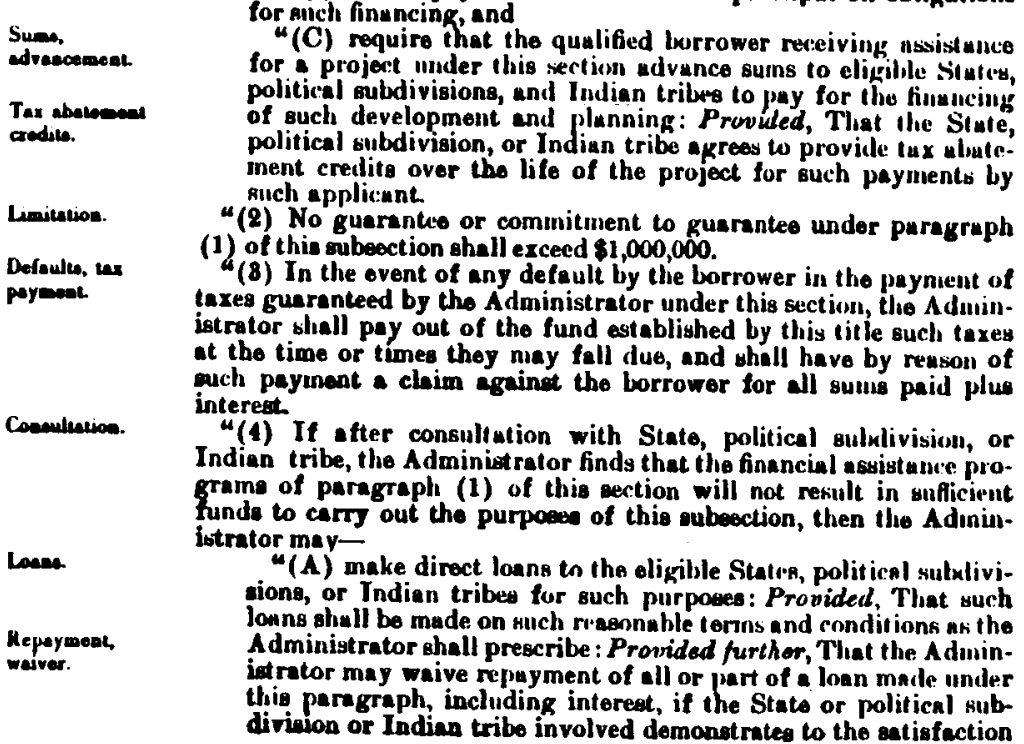

of the Administ rator that due to a change in circumst unees there will in: but udverse: impucts resulting from such project thut would problubly cuast: such State, sulndivision, or tribe to defult on the mant; or

"(B) require that any community development and planning rosts which ure nssinciuted with, or result from, such project, and which are deterinined by the Administrator to be appropriate for projuct.

“(5) The Administrator is further euthorized to muke grants to States, political subdivisions, or Indian iribes for studying and planning for the potential economic, environmentel, and social conse-

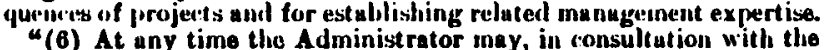
Secrotury of the Trensury, redeem in whole or in part, out of the fund

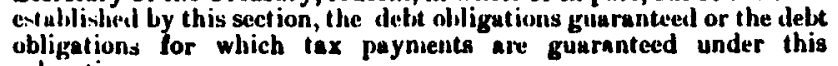

"(7) When one or more States, political sululivisions, or Indian trilwes would be eligitle for assist unce under this subsection, but for the fuct that const ruction und operution of the project orcurs outside its jurisdiction, the Administ ralor is authorized to provide, to the greatest "(8) Such anounts us may be nicessary for direct loans and grants (8) Surh amounts us may br incessary for direct loans and grants pursuant to this su

"(D) The Administrntor, if appropriate, sliall provide assistunce in Foderal stere. the finuncing of up to 100 p'r centum of the costs of the required couninunit y development and plunning pursunut to this section.

"(10) In carrying out the provisions of this section, the Aduninistra- Facility tith

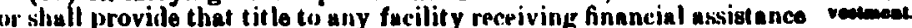
under this section shull vest in the epplicable State, political eubdivision, or Indiun tribe, as appropriate, and in the crice of default by the horrower on a lown giarnntee inade or committed under subsection (b) of this section, stich facility shall not he considered a project asset for the purposes of section 202 of this Act.

"(11) The Administrator shall not use his authority under this subsection to provide Federal assistance unless any Fedleral funds Ausminents of 1976 (Public Law 94-377) to the Stute from the lease 30 USC 191.

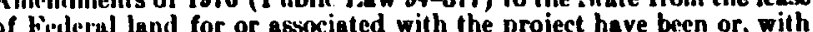
A Federul slututes, to financing such essential community development or planning directly resulting froll, or necessitated by, projoct on leused Federal lends.". 


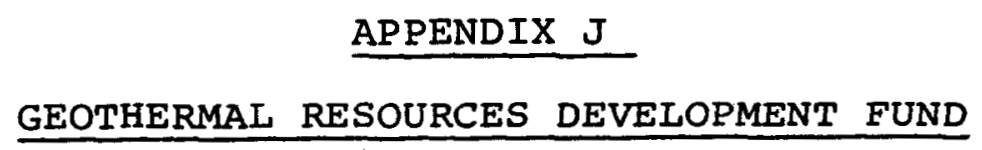

BUDGET FOR FISCAL YEAR 1979 
Geothermal Resources Development Fund

For carrying out the Loan Guarantee and Interest Assistance Program as authorized by the Geothermal Energy Research, Development, and Demonstration Act of $1974, \$ 15$ million to remain available until expended: provided that the indebtness shall not exceed the aggregate of $\$ 300$ million. Provided further, that after September 2, 1984, no part of this or any other appropriation for the purposes of the Loan Guarantee and Interest Assistance Program shall be available for obligation (Public Works for Water Power Development and Energy Research Appropriation Act, 1978)

$$
\begin{aligned}
& \text { Program and Financing } \\
& \text { (in thousands of dollars) }
\end{aligned}
$$

Identification Code 89-0206-0-1-271

$$
1977 \text { actual } 1978 \text { est. } 1979 \text { est. }
$$

Program by activities:

Production, demonstration, and distribution (program costs, funded)

$635 \quad 44,345 \quad 1,990$

Change in selected resources (undelivered resources)

10

10 10

10.00 Total obligations (object class 25.0 )

645

44,355

2,000

Financing :

1977

1978

1979

21.40 Unobligated balance available, start of year

$-$

29,355

$-2,000$

24.40 Unobligated balance available, end of year

29,355

2,000

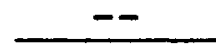

40.00 Budget authority (appropriation)

$30,000 \quad 15,000$ 
Relation of obligations as outlays: 71.00 Obligations incurred,
net

72.40 Obligations balance, start of year

74.40 Obligations balance, end of year

90.00 outlays
645

$42,355 \quad 2,000$

$-$

$326 \quad 36,081$

$\frac{-326}{319} \quad \frac{-36,081}{6,600} \frac{-32,081}{6,000}$

Production demonstration and distribution - to make available the financial resources needed for commercial development of geothermal energy, DOE is administering a Federal loan guaranty program. The objectives of the loan guarantee program are:

1) to encourage and assist the private sector to accelerate development of geothermal resources by minimizing lender's financial risk associated with the introduction of new technology; and 2) to develop normal borrower-lender relationships that will in time encourage the flow of credit without the need for Federal assistance. Implementation of the loan guarantee program is coordinated closely with the Department of Interior's Geothermal Leasing Program and with DOE's research and development effort.

The Status of the loan guarantee program authority is provided below: 


\section{Loan Guarantees}

(in thousands of dollars)

1977 actual 1978 est. 1979 est.

Balance of aggregate authorization, start of year -- $\quad 190,950 \quad 215,950$

Increase in aggregate authorization

$200,000 \quad 100,000 \quad$--

Guarantees made

$9,050 \quad 75,000 \quad 12,500$

Balance of aggregate authorization, end of year

$\begin{array}{lll}9,050 & 75,000 & 12,500 \\ 190,950 & 215,950 & 203,450\end{array}$

The new loan guarantees totaling $\$ 12,500$ thousand planned for 1979 will be used to provide incentives for resource development and nonelectric projects.

Source: Executive office of the President, Office of Management and Budget, Washington, D.C. 


APPENDIX K
LOAN GUARANTY APPLICATION FORM


Form ERDA 634

(9-76)

US. ENERGY RESEARCH AND
DEVELOPMENT AOMINISTRATION APPLICATION FOR LOAN GUARANTY

(Geothermal Projects)

Use additional sheets as necessary for items for which there is insufficient space.

\section{NAME OF APPLICANTS}

The following applicants request a Federal guaranty for a ban a hereinafter described: 1. LENDER

\begin{tabular}{l|l|l|}
\hline a. NAME & a. NAME \\
\hline b. AODRESS (street and mumber; city, stane and ZIP code) & O. ADORESS (street and number; city, state and ZIP code) \\
\hline C. DESCRIPTION OF PRIMARY BUSINESS & C. TYPE OF ORGANIZATION: (e.g., CORPORation, Partnership, Etc.) \\
\hline
\end{tabular}

II. AUTHORITY TO ACT

The lender and the borrower respectively authorize the individuals designated below to act in their behalf under the terms and conditions of any guaranty contract executed between ERDA and the lender and borrower:

\section{FOR THE LENDER}

a. NAME
TITLE
b. AOORESS (street and number, city, state and ZIP code)
c. TELEPHONE

a. NAME

TITLE

b. ADDRESS (street and number, city, state and ZIP code)

C. TELEPHONE

\section{DESCRIPTION OF THE BORROWER}

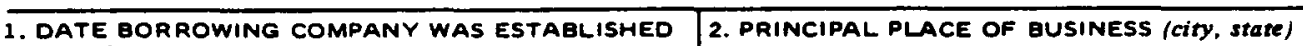
(month, year)

3. DESCRIPTION OF PRIMARY BUSINESS

4. IF THE BORROWER IS A SUBSIDIARY OR AFFILIATE OF ANOTHER ORGANIZATION, COMPLETE I-d BELOW

\begin{tabular}{l|l}
\hline a. NAME OF PARENT OR AFFILIATE & D. ADDRESS
\end{tabular}

\begin{tabular}{l|l|l|}
\hline C. NAME AND TITLE OF CONTACT OFFICIAL FOR PARENT OR AFFILIATE & d. TELEPHONE
\end{tabular}

5. PRINCIPAL OFFICERS AND DIRECTORS OF THE BORROWER ASSOCIATED WITH THE PROJECT

Name

Title

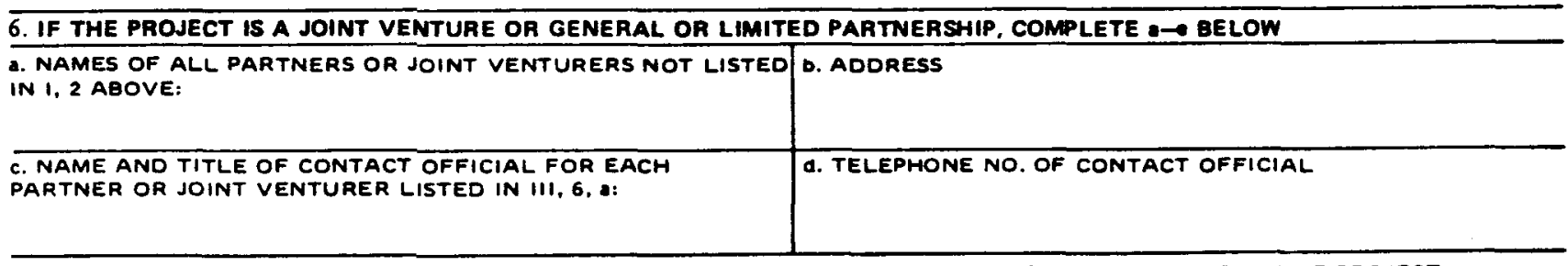

- BRIEF DESCRIPTION OF THE SCOPE AND EXTENT OF ANY PARTNERS' OR JOINT VENTURERS' ROLE IN THE PROJECT: 
IV. PROJECT DESCRIPTION

\begin{tabular}{l|l}
\hline 1. OATE PROJECT IS TO BE INITIATED & 2. SCHEDULED COMPLETION DATE \\
\hline 3. BRIEF DESCRIPTION INCLUDING LOCATION ANO CURRENT STATUS OF PROPOSEO PROJECT
\end{tabular}

$\begin{aligned} & \text { 5. DATE CONTINUOUS OPERATING REVENUE FROM THE } \\
& \text { PROJECT IS ANTICIPATED TO BEGIN: }\end{aligned}$
\begin{tabular}{l|l|l|l} 
7. SOURCE OF PROJECT INCOME & $\begin{array}{l}\text { 6. ANTICIPATEO AVERAGE ANNUAL PRODUCTION OF USEFUL } \\
\text { ENERGY (in } m w \text { hours or equivalent): }\end{array}$ \\
2. Names and Addresses of Potential Customers & b. Name of Contact Official & c. Telephone No. \\
\hline & & & \\
\hline
\end{tabular}

8. ESTIMATED PAYMENT OF ROYALTIES TO FEDERAL GOVERNMENT OVER LIFETIME OF PROJECT:

$s$

9. BRIEF DESCRIPTION OF METHOD OF CALCULATING ROYALTIES

\begin{tabular}{|c|c|c|c|c|c|}
\hline \multicolumn{6}{|c|}{ V. PROJECT FUNDING } \\
\hline $\begin{array}{l}\text { 1. TOTAL ESTIMATED } \\
\text { AGGREGATE COST OF } \\
\text { PROJECT }\end{array}$ & $\begin{array}{l}\text { 2. PORTION OF P } \\
\text { COST TO BE FR } \\
\text { GUARANTEED }\end{array}$ & $\begin{array}{l}\text { ROJECT } \\
\text { EDERALLY } \\
\end{array}$ & $\begin{array}{l}\text { 3. FACE AMT. OF } \\
\text { PROPOSED LOAN: } \\
\text { S }\end{array}$ & $\mid \begin{array}{c}\text { 4.PORTION OF LOAN } \\
\text { TO BE GUARANTEED: } \\
x\end{array}$ & $\begin{array}{l}\text { 5. FACE AMT. OF } \\
\text { GUARANTY COM- } \\
\text { MITMENTS: }\end{array}$ \\
\hline \multicolumn{6}{|c|}{ VI. LOAN TERMS pattach complete amornization schedule) } \\
\hline 1. INTEREST RATE & $\begin{array}{l}\text { 2. LOAN DURA- } \\
\text { TION (years, } \\
\text { months) }\end{array}$ & $\begin{array}{l}\text { 3. PAYMEN } \\
\text { BEGIN /C }\end{array}$ & $\begin{array}{l}\text { TOF INTEREST TO } \\
\text { (ate) }\end{array}$ & $\begin{array}{l}\text { 4. PAYMENT OF PRIN- } \\
\text { CIPAL TO BEGIN } \\
\text { (month, year) }\end{array}$ & $\begin{array}{l}\text { 5. FREQUENCY OF PAY } \\
\text { MENT: } \\
\text { Interest: } \\
\text { Principal: }\end{array}$ \\
\hline
\end{tabular}

6. DIRECT PROJECT COSTS INCURRED TO DATE:

7. LENDER'S NON-GUARANTEED PORTION OF THE LOAN: 3 $\boldsymbol{s}$

8. OTHER LENDERS SMARING IN THE GUARANTEED LOAN: Name and address of lender

Amount of toan Shared (\$) 
VII. DESCRIPTION OF OTHER PROJECT FUNDING

1. Other Committed Sources of Non-Federel Funds

\begin{tabular}{|c|c|c|}
\hline \multirow{4}{*}{ A. } & \multirow[t]{2}{*}{ a. COMPANY NAME } & d. $\$$ AMOUNT \\
\hline & & 6. DATE AVAILABLE \\
\hline & b. CONTACT OFFICIAL & \multirow[t]{2}{*}{ 1. FORM OF FUNDING } \\
\hline & c. TELEPHONE NO. & \\
\hline \multirow{4}{*}{ B. } & \multirow[t]{2}{*}{ a. COMPANY NAME } & d. AMOUNT \\
\hline & & \multirow{3}{*}{$\begin{array}{l}\text { 6. DATE AVAILABLE } \\
\text { †. FORM OF FUNDING }\end{array}$} \\
\hline & b. CONTACT OFFICIAL & \\
\hline & c. TELEPHONE NO. & \\
\hline \multicolumn{3}{|c|}{ 2. Amount and Souree of Other Foderal Amistence Availeble or Expected To Be Made Availeble: } \\
\hline \multirow{4}{*}{ A. } & \multirow[t]{2}{*}{-. AGENCY NAME } & \multirow{2}{*}{\begin{tabular}{|l|} 
d. $\$$ AMOUNT \\
D. DATE AVAILABLE
\end{tabular}} \\
\hline & & \\
\hline & b. CONTACT OFFICIAL & \multirow[t]{2}{*}{ 1. GRANT OR CONTRACT NO. } \\
\hline & C. TELEPHONE NO. & \\
\hline \multirow{4}{*}{ B. } & \multirow[t]{2}{*}{ 2. AGENCY NAME } & O. S AMOUNT \\
\hline & & \\
\hline & D. CONTACT OFFICIAL & \multirow{2}{*}{ 1. GRANT OR CONTRACT NO. } \\
\hline & c. TELEPHONE NO. & \\
\hline
\end{tabular}

VIII. ATTACHMENTS

This application will not be acted upon until all required attachments have been submitted.

List and identify all attachments made part of this applleation:

\begin{tabular}{l|l|l}
\hline \multicolumn{3}{c}{ IX. PERSON AUTHORIZED TO ORDER EXPENDITURE OF THE BORROWER'S FUNDS: } \\
\hline NAME & SIGNATURE & TELEPHONE NO. \\
TITLE & $X$. CERTIFICATIONS \\
\hline
\end{tabular}

a. The LENDER attests that the above loan will not be made without a Federal guaranty bocause:

b. The BORROWER described herein attests that he qualifies for preferential consideration as a small business entity as defined in 10 CFR 790.5(i) and (j): $\square$ Yes $\square$ No

c. The APPLICANTS affirm that they are the persons who executed the foregoing instrument; they have read the same and instructions and attachments and know the contents thereof; that the matters stated herein are true to their knowledge except such matters as are stated to be upon information and belief, and as to those matters they believe them to be true:

FOR THE LENDER:

FOR THE BORROWER:

(rignorine)

(dete)

(signature)

(date)

The U.S. Code, Title 18 , Section 1001 , makes it a criminal offense to make a willfully false statement or misrepresentation to any department or agency of the United States as to any matter within its jurisdiction. 
This AGREEMENT is entered into as of pursuant to Title II of the Geothermal Energy Research, Development, and Demonstration Act of 1974 (P.L. 93-410) and the DOE Loan Guaranty Regulations contained in $10 \mathrm{CFR}$ Part 790, be and between:

The United States Government (hereinafter referred to as the "Government"), acting through the Department of Energy (hereinafter referred to as "DOE"), (hereinafter referred to as the "Borrower"),

and (hereinafter referred to as the "Lender").

WHEREAS: Borrower is planning a project for the use of geothermal resources in for (hereinafter referred to as the "Project"), which it is unable to finance through usual sources, and therefore, desires to secure a Government guaranty of certain loans to be made to it by Lender, and

WHEREAS: The Lender is prepared to lend money for such project if a sultable guaranty of the government can be secured.

NOW, THEREFORE, in consideration of the foregoing and the covenants contained herein, the parties agree as follows:

\section{W I T NES S E T H}

WHEREAS, Borrower is planning a project for the commercial development of practicable means to produce, with environmentally acceptable processes, useful energy from Geothermal resources, in

(hereinafter referred to as "the Project"), and

WHEREAS, Borrower is able to supply a portion of the cost of the Project but needs to borrow a sum which does not exceed $75 \%$ of the aggregate cost of the Project, and its desired loan does not meet the standards of available lenders without the presence of a Federal guaranty, and

WHEREAS, DOE is prepared to provide such a guaranty of such loan on the terms and conditions outlined hereln, and

WHEREAS, Lender is prepared to make such loan pursuant to such guaranty. 
NOW, THEREFORE, in consideration of the foregoing and the covenants contained herein; the parties hereto hereby agree as follows:

\section{SECTION 1: INTRODUCTION}

1.1 Definitions. All terms used in this Guaranty Agreement shall have the meaning accorded to them in $10 \mathrm{CFR}$ Part 790 . Any terms not therein defined but which are defined herein or in the Loan Agreement shall have the meaning accorded to them herein or in the Loan Agreement. The following terms as used in the Guaranty Agreement shall have the following meanings:

A. "Guaranty" means this Guaranty Agreement.

B. "Loan Agreement" means the document to which this Guaranty constitutes Exhibit $I$ and which in turn constitutes Exhibit $A$ to this Guaranty.

C. "Manager" means manager of DOE's San Francisco Operations Office, or a representative who is duly and properly delegated in writing to act for him, a copy of which delegation is delivered to Borrower and to Lender, to perform the functions required of the Manager under the DOE Regulations.

D. "Background Patent" means a domestic patent showing an invention or discovery which is not a Subject Invention and which is owned or controlled by the Borrower at any time through the completion to this project:

(1) Which the Borrower, but not the Government, has the right to IIcense to others; and

(2) Infringement of which cannot reasonably be avolded upon the practice of any specific process, method, machine, manufacture or composition of matter (including relatively minor modifications thereof) to continue or practice the results of this project.

E. "Secretary" means the Secretary of the United States Department of Energy or a representative authorized by the Secretary. 
F. "Other Proprletary Rights" means rights in trade secrets relating to, recorded information regardless of form or characteristics, or a scientific or technical nature. It may, for example, document research, experimental, developmental, or demonstration, or engineering work, or be usable or used to define a design or process, or to procure, produce, support, maintain, or operate material. It may be graphic or pictorial delineations in media, such as drawings or photographs, text in specifications or related performance or design type documents or computer software or printouts.

Examples include research and engineering data, engineering drawings, and associated 11sts, specifications, standards, process sheets, manuals, technical reports, catalog item identification, and related information. It does not include financial reports, cost analyses, and other information incidental to project administration.

G. "Background Proprietary Rights" means other proprietary rights that were developed at private expense, and utilized or incorporated in the Project.

\subsection{Guaranty.}

DOE by this Agreement, and subject to the terms and conditions herein set forth, does hereby guarantee and promises to pay to Lender on demand, in writing, subject to DOE's rights under section 4.5 of this Agreement, in the lawful money of the United States of America, the amount of unpaid principal approved by DOE to be disbursed and accrued interest owing to Lender by Borrower under the terms of the Loan Agreement. DOE's obligation-to Lender under this Guaranty Agreement will arise only in the event that there has been a default (as defined in Section of the Loan Agreement).

\subsection{Purpose.}

The purpose of the project is 


\subsection{Term of Guaranty.}

This Guaranty shall be effective 19 and shall expire upon the payment of all principal and interest owing to Lender by Borrower under the Loan Agreement (Exhibit A) unless sooner terminated in accordance with this Agreement; or as it may be mutually extended or terminated by the parties.

\section{SECTION 2: THE LENDER'S COVENANTS}

\subsection{LENDER agrees that:}

A. It shall exercise such care and diligence in the disbursement, servicing, and collection of the Loan as would be exercised by a reasonable and prudent lender in dealing with a loan without a guaranty;

B. It will not amend the Loan Agreement without prior written approval of the Manager;

C. Without the prior written consent of the Manger, it will not grant Borrower any further extension of time over and above any period of grace for the making of any payment in whole or in part under the Loan Agreement nor, except upon the occurrence of an event of default under the Loan Agreement, will it accelerate the scheduled payments under the Loan;

D. It will, within working days after receipt by it of the financial statements required to be furnished to it pursuant to Section 4.1 (c) of the Loan Agreement, deliver or cause to be delivered to DOE coples of all such reports, together with a statement that the Bank has reviewed and evaluated the reports. The statement will include an opinion by an officer of the Lender regarding whether or not the financial statements indicate that the status and condition of the loan are such that the Borrower is In compliance with the terms of the Loan Agreement.

E. It w111 notify the Manager in writing:

(1) That the first disbursement on the Loan is ready to be made together with evidence from the Borrower that the Project has commenced or is about to commence;

(2) Of the date and amount of each disbursement under the Loan; 
(3) Of any non-payment by Borrower of any princlpal or interest as required by the Loan Agreement, if such non-payment is not cured within the grace period, together with evidence of appropriate notifications made by it to the Borrower;

(4) Of any fallure known to it by an intended source of capital to honor its commitment;

(5) Of any fallure by the Borrower known to 1t, to comply with terms and conditions as set forth in the Loan Agreement or Loan Guaranty Agreement; and

(6) When it believes that the Borrower may not be able to meet any further scheduled payment of principal or interest.

2.2 Lender agrees that disbursements by Lender to Borrower under the Loan shall only be made pursuant to:

A. A written request from Borrower to Lender stating the purpose for which the disbursement is requested in such detail as the Manager may request, and

B. Receipt by Lender of an attestation (signed by a person authorized to order expenditure of Borrower's funds) that such disbursements will be used only for the purpose stated in the request and to the effect that funds requested will be used by Borrower to pay Borrower's costs incurred, or to be Incurred for the Project, and

C. Prior recelpt by Lender of a written Notice from the Manager that the disbursement is approved. (Coples of items furnished in A. and B. above must be sent by Lender to the Manager prior to approval.)

2.3 Upon the occurrence of an Event of Default under the Loan Agreement:

A. The Lender agrees to take such steps as may be commercially reasonable to preserve and maintain the collateral granted to it under Section of the Loan Agreement, so as to achieve maximum recovery upon Ilquidation of the collateral.

B. Concurrently with payment in full of all amounts guaranteed by DOE, It will assign to the Government and transfer and deliver to the Manger the loan documents together with all collateral documents evidencing any and all securlty for the loan held by it. 
Loan Guaranty Agreement

2.4 Lender agrees not to waive or relinquish, without the prior written consent of the Manager, any collateral or guaranty for the Loan.

2.5 Lender agrees to pay DOE an annual user charge of one per cent (1\%) of the anticipated average amount of the guaranteed portion of the Loan that is estimated to be outstanding during the year. The first year's charge, \$, shall be pald upon execution of this Guaranty and subsequent payments shall be made by Lender annually on the annfversay date of the execution of this Guaranty. If the Borrower does not initiate the project within sixty $(60)$ days after the execution of this Loan Guaranty Agreement, the Manager shall reimburse reimburse to the Lender the full amount of the user charge pald by the Lender if the charge has not been passed on to the Borrower. The user charge may be passed to the Borrower by the Lender and, in such instances, may be included in the project cost.

2.6 The Lender may not assign to another Lender rights and obligations under the Loan or this Loan Guaranty Agreement, without the prior written consent of the Secretary. The Lender, however, may provide another Lender with participating shares in the Loans without the prior written consent of the Manager. When participating shares are so provided, the Lender shall give written notice to the Manager and the Borrower. In the event there are participating shares, the original Lender shall continue to be responsible for and perform the provisions of the Loan Guaranty Agreement pertaining to the Lender unless the Manager approves a substitute lender.

2.7 Lender agrees and Borrower concurs that DOE or its duly authorized representatives shall have access to any and all of its records and documents relating to the Loan, for such time periods as Lender maintains such records in accordance with its standard operating procedures.

\section{SECTION 3: BORROWER'S COVENANTS}

3.1 The Borrower agrees that 1t will:

A. Initiate activity on the Project within days after execution of this Agreement;

B. Obtain all necessary permits, 11censes, and approvals necessary for the performance of the Project;

C. Comply with all laws and regulations applicable to the Project; 
D. Comply with requirements of 10 CFR Section 790.23 , and the specific language of $10 \mathrm{CFR}$ Section 790.23 (C) is hereby Incorporated by reference into this Agreement;

E. Comply with the following Federal Procurement Regulations which are listed below and by this reference incorporated into this Agreement:
(1) Clean AIr and Water - 41 CFR Section 1-1.2302.2
(2) Construction Equal Opportunity - 41 CFR Section 1-12.803-4
(3) Certificate of Non-segregated Facillties - 41 CFR Section 1- 12.803-10 (D).

F. Not undertake any work in connection with the Project (by contract or grant) for a Federal agency without the Manager's written finding that performance of the work will not adversely affect its ability to comply with pertinent terms and conditions in the Loan Agreement and Loan Guaranty Agreement;

G. Acquire capital equal to at least $25 \%$ of the project costs;

H. Make all reports described in Exhibit B, Reports, attached to this Agreement and by this reference made a part hereof, within the times allowed for the submittal of such reports;

I. Notify the Manager of any deviation in Project planning, management, implementation procedures or techniques from those set forth in the Application for a loan guaranty or the Milestone Schedule which may have a significant impact on any aspect of the Project; and

J. Consult and cooperate with DOE and its agents and representatives to resolve any problems which may arise with respect to any aspect of the Project throughout the term of the guaranteed loan.

\subsection{During the term of this Guaranty, Borrower w111:}

A. Identify and report in writing to the Manager when a patent application on a subject invention is filed in any country, and when a patent issues on a subject invention.

B. Obtain prior written consent of the Manager to transfer rights to third parties in: (a) subject inventions and/or (b) other proprletary rights resulting from this Project. 
Loan Guaranty Agreement

\subsection{Borrower agrees that:}

A. Employees and representatives of DOE and other Federal agencies shall, with the Manager's approval, have timely access to the project site at all reasonable times, and will assure availability of all Information within its control related to the Project to permit the Manager as is necessary to determine technical progress, soundness of financial condition, management stability, compliance with environmental protection standards and requirements, and other matters pertinent to the Guaranty. In addition, the Borrower agrees that the Manager or his duly authorized representative may have access to all its books, records and other relevant documents related to the Guaranty for a period up to three years after the conclusion of the term of this Agreement.

B. Except as hereinafter provided in this paragraph, all information flowing from the Project will be open to public dissemination. Trade secrets, commercial and financial information, geological, geophysical, and geographical information and data (including maps) concerning wells which the Borrower makes available to DOE during the preliminary discussion or at any time throughout the duration of the Project on a privileged or confidential basis, will be so treated by DOE and, subject to Freedom of Information Act requirements, will not be publicly disclosed without prior written approval of the Borrower. In order to assist DOE In carrying out this provision, Information deemed by the Borrower to fall within one of the foregoing categories shall be identifled and appropriately marked by the Borrower.

3.4 Borrower agrees to obtain flood insurance as required by $10 \mathrm{CFR}$ Section 790.24, if it is determined necessary at some future date.

\section{SECTION 4: EVENTS OF BREACH}

\subsection{It is agreed that:}

A. Upon a finding by the Manager that the Lender has breached any of the covenants contained in Section 2 of th1s Guaranty Agreement or any other material term or condition of this Guaranty Agreement or the Loan Agreement, and the breach shall not have been cured within thirty (30) days after written notice to Lender of the finding describing the material breach, the Guaranty shall be terminated and the government shall have no obligation hereunder. 
B. Upon such finding and notice by the Manger of such finding, the Borrower will be allowed substitute lender. days to acquire an approved

C. Lender may continue to make approved advances as provided herein Under the Guaranty for a perlod of no longer than the during which Borrower may seek a substitute lender. I $\overline{\text { a }}$ days substitue lender is procured during such period and a new Guaranty negotiated between DOE, Borrower and the substitute lender within such period, then this Guaranty shall not cover any Advances made after the date of 1ssuance of the new Guaranty by DOE to the substitute lender.

D. If a new Guaranty Agreement is not negotlated with a substitute lender within such - day period, then this Guaranty shall not cover any Advances made after the end of such period.

E. Lender may not recover any amount in excess of disbursements approved by DOE together with accrued interest thereon.

4.2 Upon a finding by the Manager that the Borrower is in breach of any of the covenants contained in Section 3 of this Agreement, or of any other term or condition of this Guaranty Agreement or the Loan Agreement, and the breach shall not have been cured within thirty (30) days after written notice to the Borrower of the finding describing the breach, or If an Event of Default as specified in Section of the Loan Agreement has occurred, this Loan Guaranty shall be reduced to the amount approved for disbursement plus any accrued interest due on those approved disbursements as of the date the notice from the Manager is received by the Lender. Any subsequent disbursements will not be covered by the Guaranty.

4.3 Upon default by the Borrower and notification by the Lender, and to the extent that sufficient reserves exist in the Geothermal Resources Development Fund: (1) upon approval of the Secretary, the Manager shall, within sixty (60) days after recelpt of such documents pay to the lender, the guaranteed amount of unpald principal and accrued Interest outstanding at the date of default; and (2) during the period beginning from receipt of such documents and until payment is made by the Manager, interest payable by the United States will accrue on the guaranteed debt at a rate to be determined by the Secretary of the Treasury taking into consideration current average market yields on outstanding shortterm Treasury securities. 
4.4 Upon a determination by the Manager that a default has occurred (except where interest assistance 1 s provided as set forth in Section 4.5 below) the following shall apply with respect to patents and proprietary data:

A. Foreground. Borrower agrees to convey to the Government, upon request, the entire right, title, and interest throughout the world in any patent applications and patents resulting from subject Inventions, and other proprietary rights accruing to the Borrower and resulting from the Project. These conveyances shall be duly executed instruments and such other papers as are deemed necessary to vest in the Government the entire right, title, and interest to enable the Government to exercise full and complete ownership and control over these assets.

B. Background. For a perlod of flve years after the date of default, and upon the Secretary's determination in writing that it is in the public interest, Borrower agrees to license background patents and background proprietary rights upon reasonable terms and conditions, and under conditions to protect the confidentiality of information, to domestic third parties to continue or practice the results of the Project.

C. Borrower's License. Upon conveyance to the Government of title to the above patent applications, patents and other proprietary rights referred to in Subparagraph $A$ above, Borrower may reserve upon request a revocable, non-exclusive license in each of said patent applications, patents, or other proprietary rights, upon such reasonable terms and conditions as may be specified by DOE at the time of said request.

\subsection{Nowithstanding any other part of this Agreement:}

A. In the case of fallure by the Borrower to make interest payments as required in the Loan Agreement, the Manager reserves the right and shall, within a period of thirty (30) days after receipt of notice of failure to pay interest, pursuant to the provisions of 10 CFR Section 790.7, determine whether an interest assistance contract shall be executed. In the event that interest assistance is not warranted, the Manager shall so notify the Secretary and the Lender. The lender shall make avallable without delay such documents and certifications as the Manager may reasonably require evidencing the Lender's compliance with notification provisions of the Loan Guaranty Agreement. 
B. In the event interst assistance is warranted, DOE w111 enter Into an agreement with the Borrower to pay Lender for and on behalf of the Borrower, upon the same terms and conditions provided in the Loan Agreement and the Note, interest payments then in arrears and interest payments which thereafter become due and payable on the unpald balance of the Loan. Lender agrees to accept interest paid from DOE in lieu of the Borrower.

4.6 The Manager is under no obligation to exercise the rights given him In this Agreement and may, when he determines that it is in the best interest of the Government, waive or delay the exercise of any of those rights including, but not ifmited to, the volding or reducing of the Guaranty.

\title{
SECTION 5: ADDITIONAL REQUIREMENTS
}

\subsection{Communications.}

All notices, demands, or other communications shall be in writing addressed as follows:

A. If to DOE:

\author{
Manager \\ San Francisco Operations Office \\ Department of Energy \\ 1333 Broadway \\ Oakland, CA 94612
}

B. If to the Lender:

C. If to the Borrower:

\subsection{Survival of Agreement.}

This Guaranty Agreement shall be binding upon the Lender, Borrower, and DOE and upon their successors and/or assignees and shall survive payment by the United States. No delay or fallure of the Secretary or the Manager In the exercise of any right or remedy and not single or partial exercise of any such right or remedy shall preclude any further exercise thereof, and no action taken or omitted by the Secretary or the Manager shall be deemed a waiver of any right or remedy. 


\subsection{D1sputes.}

Any dispute arising under this Agreement should be sent to the Manager. All decisions by the Manager relating to disputes arising under the Loan Guaranty Agreement or Loan Agreement shall be in writing. The Borrower or Lender, as applicable, may request the Manager to reconsider any such decision. If not satisfied with the final decision made by the manager, the Borrower or Lender, upon receipt of such written decision, may appeal the decision within thirty (30) days, in writing, to the Chairman, Board of Contract Appeals (EBCA), Department of Energy, Washington, DC 20545. That Board when functloning to resolve such loan guaranty disputes, shall proceed in the same general manner as when it presides over appeals involving contract disputes. The decision of the Board with respect to such appeals shall be the final decision of the Agency.

\subsection{Other Loans.}

It is agreed that: (I) the terms and conditions set forth in any non-guaranteed loan relating to the project shall be acceptable to the Manager, and (2) the non-guaranteed loan shall be subordinate to the guaranteed loan.

\subsection{Officials Not to Benefit.}

No member of, or delegate to Congress, or resident commissioner, shall be admitted to any share or part of this Agreement, or to any benefit that may arise therefrom; but this Section 5.5 shall not be construed to extend to this Agreement if made with a corporation for its general benefit.

\subsection{Applicable Law.}

Interpretation of this Loan Guaranty and the rights and obligations of the parties thereto shall be governed by the laws of the United States of America. Nothing in this Agreement shall be construed to modify requirements imposed on the Borrower or Lender by Federal, State, or local government agencles in connection with permits, licenses or other authorization to conduct or finance geotheraml activities. 
Loan Guaranty Agreement - 13 -

IN WITNESS WHEREOF, the United States of America, the Borrower, and the Lender(s) have extended this Agreement, intending to be legally bound thereby.

THE UNITED STATES OF AMERICA

BY

TITLE

(Borrower)

(Lender)

BY

BY

TITLE TIILE

BY

TITLE 